Katalin Fehér

New media and digital marketing: synergy models and recommendations for convergence of the two disciplines

\section{Pál Danyi}

Expected impact of Artificial Intelligence on Pricing

Ilona Miklós

A Fault in Our Stars: Competitiveness among Michelin-star Restaurants

\section{Noémi Munkácsi}

Special marketing characteristics of heating products. Perceived quality attributes of residential heating products along the decision-making process
Boglárka Eisingerné Balassa - Ferenc Bakó The attitudes of hungarian homosexual men towards clothing brands

\section{Bálint Szabó}

Different appearance of user-centred aspects in software development

| 17 Qualitative research on the practice of domestic companies

Csilla Molnárné Konyha

| 31 Promotion optimization for universities with dynamic programing

Book review 


\title{
Új média és digitális marketing: szinergia-modellek és ajánlások a két szakterület közelítéséhez
}

\author{
Fehér Katalin \\ Budapesti Gazdasági Egyetem
}

\begin{abstract}
A TANULMÁNY CÉLJA
Elsődleges cél a gyakorlatban és az elméletben is hasznosítható szinergia-modelleket fejleszteni az új média és a digitális marketing közös tudományos-kutatási trendjeinek elemzésével. Ennek oka az egyelöre viszonylag kisszámú nemzetközi publikáció és kutatás a közös metszetben - összemérve a diskurzusközelítés és a prognózis-alkotás sokoldalú lehetőségeivel.
\end{abstract}

\begin{abstract}
ALKALMAZOTT MÓDSZERTAN
A tanulmány három pillérre épül. Az első szakirodalmi összefoglalót ad a digitális technológia által biztosított keretrendszerről az interdiszciplína alapforrásai alapján. A második szűri és összegzi a vonatkozó akadémiai trendeket mértékadó tudományos és kutatási adatbázisok mentén. Az utolsó pedig az első két szinergia-modell és a feltörekvő trendek alapján ad jövőképet.

\section{LEGFONTOSABB EREDMÉNYEK}

Az új média, mint kiterjedt és átfogó társadalmi-kulturális értelmezési keret, valmint a digitális marketing fókuszáltabb kutatási szakterületei erős szinergiát mutatnak. Interdiszciplinaként egyes kutatásaik elválaszthatatlanok, s erőforrásként értelmezhetők egymás számára. Az első modell hangsúlyozza a technológiai determinizmus mérsékelt megközelítésének szerepét. A második kiemeli a már megkerülhetetlen szakterületeket a digitális marketingben és az új média kontextusában - közös metszettel és az eltérő megközelítésekkel egyaránt. A harmadik pedig a formálódó technológiai trendekkel és azok következményeivel ad jövőképet a két tudományterület szinergiájában.
\end{abstract}

\section{GYAKORLATI JAVASLATOK}

A tanulmány a fent röviden ismeretett modellek alapján fogalmazza meg a szinergia-területek együttmüködésének jelentőségét és lehetőségeit a kapcsolódó kutatások és szakmák számára egyaránt.

Kulcsszavak: új média, digitális marketing, automatizáció, prosumer aktorok, fogyasztói magatartás DNS, kezdeti MI 


\section{BEVEZETÉS}

Az új média, illetve a digitális marketing tudományos megközelítései és kutatási területei figyelemreméltó átfedést mutatnak, mint feltárandó terület. Különösen érvényes ez az állítás a digitális technológia egyre szélesebb körü automatizációs és perszonalizációs kínálatának kontextusában, illetve a tartalmak és közönségtípusok diverzifikálódásának jelenségével.

Ezen tanulmány célja az, hogy akadémiai források összefoglalásával és interdiszciplináris keretben mutasson rá az új média és a digitális marketing aktuális tudományos-kutatási trendjeinek átfedéseire, illetve ezen két terület közös metszetét szinergia-alapú modellekkel összefoglalja, valamint egy jövőorientált modellben kiterjessze. A tanulmány emellett külön vizsgálja a digitális marketing peremterületein megjelenő, feltörekvő technológiákat és kísérő jelenségeiket, melyek várhatóan hosszabb távon fogják meghatározni az említett metszet alakulását. Másik oldalról kitér arra a vitára, mely az új média tudományos diskurzusában érhető a mindenütt jelen lévő vagy eltűnő médiáról. A tanulmány eszerint a koncepcionális megközelítésekre és a várható irányokra helyezi a hangsúlyt, így nem részletez mikrokutatásokat vagy más, gyorsan változó területeket. A végső cél tehát az, hogy a nagyobb trendekre építve rendelkezésre álljon egy olyan jól fókuszált interdiszciplináris metszet és jövőkép, mely közelítési lehetőséget nyújt a két szakterület képviselői számára.

\section{TECHNOLÓGIA ALAPÚ KERETMODELL}

Kiindulópontul az interdiszciplínát tekintve alapvetővé vált technológiai determinizmus szolgál (Hughes 1994, McLuhan 1964) - ezen belül egy modern és mérsékelt megközelítéssel. Eszerint a digitális alapokon működő információáramlás, a hálózati összeköttetések, a médiafelületek gyors kiépülése és az automatizált fogyasztói vagy közönségelérés közvetlenül vagy közvetett módon társadalmi és kulturális változásokat eredményeznek. Ezzel közös dinamikában a társadalom és a kultúra is folyamatosan visszahat a technológia és a média változásaira - ha valamennyivel lassúbb ütemben is (többek között Fehér 2016a, Kraidy 2013).

A technológiai, illetve médiadeterminizmus kontextusában javasolt két aktort azonosítani, melyek egymásra hatása közvetlenül befolyásolja a digitális marketing és az új média irányvonalait.
A két aktor eszerint a felhasználó és a szolgáltató. A felhasználó lehet egyszemélyü végfelhasználó, B2B közbenső felhasználó vagy más felhasználói típus. A lényege, hogy a technológiát alkalmazza valamilyen cél érdekében az általa elérhető digitális szolgáltatásokon keresztül. A másik oldalon szolgáltatókról beszélünk, melyek lehetnek infókommunikációs aktorok, tech-vállalatok, digitális média vagy online marketing ügynökségek, tartalomszolgáltatók, startupok és más, digitális aktivitást facilitáló résztvevők. Digitális szolgáltatókról beszélünk nemcsak a szolgáltatói társadalom kontextusában (lásd többek között Veres 2009), hanem minden kódolt megoldás esetén, amikor valamilyen szolgáltatás létrejön - az e-kereskedelmi tranzakcióktól a bloggerek vagy influenszerek információ-szintetizálásáig. A prosumerizmus (Lister és szerzőtársai 2009) elve szerint ugyanaz az aktor az egyik esetben lehet felhasználó, a másikban pedig szolgáltató, amennyiben funkcionális szerepét mindkét kategóriában be tudja tölteni.

Ha elfogadjuk a felhasználó-szolgáltató értelmezési keretet és maradunk a technológia alapú megközelítésnél, a két aktor találkozási pontjai jól definiálhatók. A kódolásnak, vagy költőibb módon megfogalmazva, az atomokról bitekre váltásnak (Negroponte 2004) köszönhető digitális technológia jelenti a kiinduló kapcsolódási pontot, ahol a felhasználó és a szolgáltató is adatosított vagy digitális aktorként érhető el. A digitális jelek számukra lefordítják a világ elemeit, struktúrákba rendezik azokat, üzeneteket és tartalmakat sürítenek össze (Flew 2014, Manovich 2001).

$\mathrm{Az}$ eléréshez a digitális technológia rendszere fizikai, illetve felhasználói vagy szolgáltatói hálózatokat biztosít. A hálózatokhoz különböző eszközökkel és jogosultságokkal lehet hozzáférni, mely egyúttal mennyiségi és minőségi mérési pontokat is biztosít a használathoz vagy szolgáltatásokhoz. A digitális és hálózati környezet a mérési pontokon rögzített adatokkal teljes folyamatokat képes detektálni, s így homogén vagy jól kódolható, értékelhető vagy előrejelezhető optimalizáló vagy hatékonysági automatizálhatók hozhatók létre (Fehér 2016a). Csak ezután következik - egy klasszikus metaforával élve - a jéghegy csúcsa, a kommunikáció, vagyis a digitális marketing és az új média müködéséből látható felszín.

A kommunikáció fogalma itt az egyik legismertebb, klasszikus megközelítésben szerepel Shannon és Weaver (1949) matematikai modellje alapján. Megközelítésük annyiban érvényes mai napig, illetve érvényes ebben a diskurzusban is, hogy a kommunikáció magáról az információ 
adásvételéröl szól valamilyen technikai médiumon keresztül, ahol a hatékonyság, az átvitel gyorsasága, és gazdaságossága, valamint az információveszteség minimalizálása alapvető kritérium. Az így értelmezett tranzaktív kommunikáción túl a digitális kódolásnak köszönhetően minden más a mélyben, feketedoboz-szerüen zajlik, részletei pedig csak bizonyos aktorok számára láthatóak a folyamatosan változó hálózati összeköttetések egy-egy metszeteként. Ez a digitális kommunikáció határozza meg technológiai megközelítéssel az új médiát és a digitális marketinget (lásd 1. ábra).

\section{1. ábra: A digitális marketing és az új média technológiai alapú kommunikációs modellje}

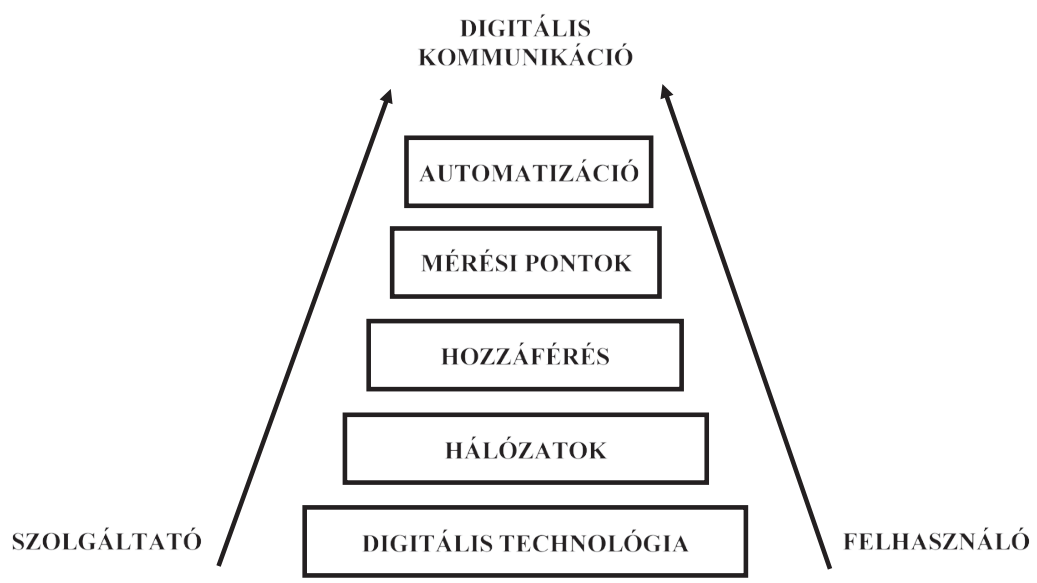

Forrás: saját szerkesztés

A szemléltető ábra erősen egyszerüsít. Nem jeleníti meg azt, hogy a szolgáltatók számára arányaiban mennyivel több a hozzáférés, nem említi meg az internetsemlegességre vonatkozó vitákat - és folytatható a sor. Pusztán azt feltételezi, hogy a digitális marketing és új média kommunikációs folyamatainak hátterében jól definiálható technológiai meghatározottság érhető tetten. Ennek kiemelt kategóriái jelennek meg az első, technológiai keretmodellben.

\section{TUDOMÁNYOS ÉS KUTATÁSI TRENDEKEN ALAPULÓ SZINERGIA-MODELL}

A következő modell célja, hogy összegezve ábrázolja azokat a tudományos diskurzusokban elérhető elméleti és kutatási témákat, melyek meghatározzák a digitális marketing és az új média fogalmait és alkalmazási területeit. Ehhez a mértékadó Scopus, EBSCO, JSTOR és Google Scholar adatbázisokban elérhető tudományos publikációk kerültek szürésre a "digitális marketing" és "új média" kifejezések együttes és külön alkalmazásával is 2015-2018-ig. Az időszak a legfrissebb tanulmányokra fókuszált a trendtémák megismeréséhez. A keresés nyelve az angol volt a legszélesebb merítés és a témaelnevezések azonosíthatósága érdekében. A szürés kizárólag a fenti adatbázisokban elérhető találatokra, azok témaköreire és tudományterületeire fókuszált. A vizsgálat ezen adatbázisok automatikusan lekérhető kvantitatív szolgáltatásainak eredményeivel dolgozott. Ez egyben azt is jelentette, hogy az adatbázisok egyes szürési feltételeivel, az adatbázisok átfedéseivel külön nem foglalkozott a vizsgálat.

Cél volt egy letisztult, felülnézeti modellt létrehozni a két diszciplína téma-átfedéseiről, eltérő fókuszairól, közelítési lehetőségeiről. A négy adatbázis végül együtt összesen több mint nyolcvanezer találatot eredményezett, melyen belül az új média szerepelt nagyobb arányban és átlagosan egyenletes eloszlással a 2015-2018-as idővonalon. A digitális marketing jóval alacsonyabban reprezentált, de a kumulált adatokat tekintve folyamatosan növekvő számmal. A közös metszet lett arányaiban a legkisebb, szintén egyenletes eloszlással az idővonalon (lásd az aránydiagramot a 2. ábrán). 
2. ábra: A digitális marketing és az új média publikációk kumulált gyakorisági aránya 2015 és 2018 között mértékadó tudományos adatbázis alapján

Forrás: saját szerkesztés

A fenti eloszlási arányt érdemes kiegészíteni a Scopus adatbázisban elérhető további dimenzióval. Ezek szerint bármennyire is közös a technológiai háttér az interdiszciplínát tekintve, a digitális marketing és az új média témakörei különböző technológiai és nem technológiai diszciplínákhoz kapcsolódnak - eltérô arányban. Részletezve:

- az új média fóként a társadalom- és bölcsészettudományokban, illetve a müvészettel kapcsolatos kutatási területeken meghatározó vizsgálati fókusz, de ezeket gyakran kiegészítik az informatikai és mérnöki tudományok,

- a digitális marketing mindenekelött az üzleti tudományok, illetve a menedzsment, a marketing és az informatikai kutatások számára jelent vizsgálati területet - és csak ezt követik a társadalom- és mérnöki tudományok,
- az új média és a digitális marketing közös vizsgálati területeihez alapvetően az üzleti, menedzsment és marketing tudományok tartoznak, de szerepet kap a társadalomtudomány, a közgazdaságtudomány, a pszichológiai és az egészségügyi szolgáltatások kutatásai is.

Részletesen feltárva a közös metszetet és az azon kívül eső kutatásokat, több mint harminc témakör definiálható a négy adatbázis kumulált kulcsszóstatisztikái szerint. Az átlátható szemléltetés érdekében a bemutatás Venn diagramon történt, a szerteágazó témák részbeni átfedései miatt betürendes felsorolással (lásd 3. ábra). 


\section{3. ábra: A digitális marketing és az új média szinergia-modellje a tudományos és kutatási trendek alapján 2015-2018 között. Metszet és eltérések: betürendes útmutató.}

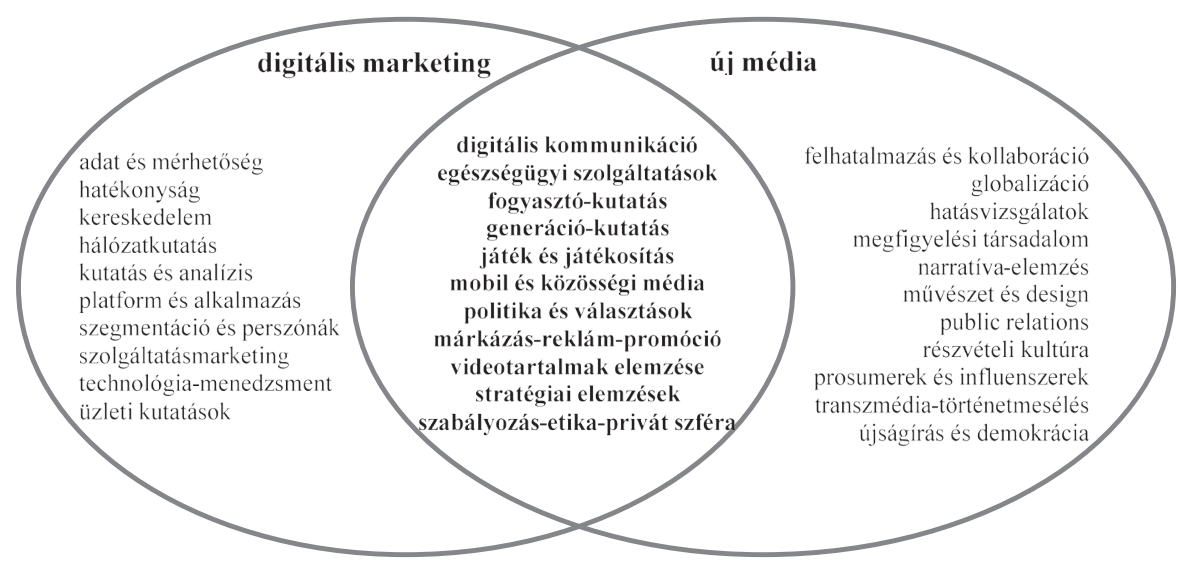

Forrás: saját szerkesztés

Kezdve az eredmények bemutatását a közös metszettel, a digitális kommunikáció kiemelt helyen szerepel, ahogyan a technológiai modellben is. A digitális kommunikáció legtöbbet elemzett vagy kutatott médiuma a videó, mely egybecseng a videótartalmak fogyasztásának jellemzően növekvő trendjével (https://www.cisco.com). A csatornákra vonatkozóan a mobil elérések és a közösségi média kap erős vizsgálati fókuszt. A digitális kommunikáció tartalmát tekintve kiemelt vizsgálati területek a márkázás, a reklám, a promóció, a politikai kampányok és a játékosítás, azaz olyan jól fókuszált területek, melyek a hatékonyságra és a fogyasztói élményutakra koncentrálnak. A technológiai megközelítésben szereplő felhasználó mindeközben fogyasztóként jelenik meg, mely automatikusan két témakört is magához vonz. Egyfelöl a generációkra jellemző fogyasztási kultúrák szempontrendszerét (lásd a hazai szakirodalomban Töröcsik 2011), másfelöl a magánélet vagy a privát szféra védelmének kérdéseit is - legföképp a perszonalizáció kontextusában (Fehér 2017). Mindezekhez keretként kapcsolódó közös területek a szabályozás és etika, illetve a stratégiai elemzések. Mindkettő aktívan és felülnézetből reflektál a folyamatosan változó digitális környezetre és azok lehetséges kihívásaira.

A metszet összefoglalása után külön vizsgálva a digitális marketing elméleti és empirikus kutatásait, a digitális technológián alapuló adatvezérelt gondolkodás, a platformok és alkalmazások elemzése, illetve a mérhetöség kerül előtérbe - mind a hatékonyság monitorozásában, mind a szegmentáció vagy perszonalizáció pontosításának érdekében. Az első modellből itt a mérési pontok intenzíven köszönnek vissza a hálózatkutatás szerepével együtt, ami kiegészül a kutatás és analízis szerepének kiemelésével. Szintén szorosan kapcsolódik a szolgáltatói szemlélet az első modellhez. Ezekkel összefüggésben a kereskedelmi és értékesitési eredmények növelhetősége alapvető vizsgálati terület. $\mathrm{Az}$ alkalmazási területek elágaznak, de a legtöbb tanulmány a turizmus és vendéglátás, az egészséggel kapcsolatos szolgáltatások és a kiskereskedelem témaköreit tárgyalja. Technológiai meghatározottságban az infókommunikációs menedzsment, míg koncepció szintjén az üzleti kutatások biztosítják a keretvizsgálatokat.

Az új média kutatása és elméleti megközelítései ezzel szemben inkább az elérhető hatásokra, a kommunikációs üzenetek terjedésre fókuszál és az ezekhez tartozó szélesebb társadalmi-kulturális kontextusokat vizsgálja. Utóbbira jellemző példák a felhatalmazott és kollaborációra nyitott fogyasztói társadalom, valamint a részvételen alapuló kultúra a globalizációban. A prosumer és influenszer jelenség, a transzmédia mint a tartalommintázat professzionális és amatőr kiterjesztése (Jenkins 2010), valamint a médiamúfajok találkozása is erős kutatási irányként jelenik meg (Zelenkauskaite 2017). Ezzel együtt olyan alkalmazási területek kerülnek górcső alá, mint például az online 
újságírás és a demokrácia, a public relations sokoldalú használata vagy a terrorizmus-kommunikáció. Jellemző kérdései, hogy ki gyakorolja a narratív kontrollt, illetve ki figyel meg kit és milyen következményekkel. Emellett elsősorban az új média vizsgálatának szerves része a design-gondolkodás, a tervező és kreatív építkezés a médiafelületekkel, illetve ide kapcsolódik az újmédia-müvészet tárgyalása is - esztétikai interpretációkkal.

A két terület összefoglalásából jól látszik, hogy mindkettőre jellemző egy sajátos terminológia és megközelítés. Ennek oka, hogy a digitális marketing inkább tartozik az üzleti tudományokhoz és fókuszál a technológiai meghatározottságra, míg az új média inkább kulturális, szociológiai és müvészeti beágyazottságú. A következő rész modellje jövőbemutató trendekkel egészíti ki, illetve összegzi a fenti két szinergia-modell interdiszciplináris megközelítését.

\section{JÖVŐ-PROGNÓZISOK KÍSÉRLETI MODELLJE}

Mérlegelve az első két modell átfedéseit, ezen belül is az első modell fö kapcsolati elemeit és a második modell metszetét, a digitális kommunikáció feltétlenül összekötő kapocs. A második modell metszete felülnézetből a stratégiai elemzésekre és a szabályozási és etikai kérdésekre reflektál, miközben olyan gyakorlati területeket vizsgál, mint a fogyasztói vagy választói online magatartás, illetve az azokat befolyásoló platformok, szolgáltatások és marketing-eszközök.

Mindezek alapján záró lépésként egy jövőorientált kísérleti modell létrehozása a cél. Forrásai az elöző szinergia-modellek és a témában a jellemzően hivatkozott források. Ezen felül külön módszertani megfontolásokra itt már nem kerül sor, hiszen nem is adható több becslésnél a jelenben elérhető jövőtechnológiák alapján.

A fenti két modellt visszaidézve egyfelöl a digitális kommunikációt támogató mérési pontok kaptak erős hangsúlyt, többek között a performancia alapú megközelítésnek és a konverziós ráták szerepének köszönhetően (Ryan 2017). Másfelől a fogyasztó és szolgáltató viszonya, illetve prosumer szerep-felcserélhetösége jelent meg markánsan, szervesen beépülve a tartalomszolgáltatásba és az értékesítésbe, és ezen belül is elsősorban a videomüfajba (www.launchmetrics.com, Burns 2016). Mindezek kiterjesztése folyamatban van a jelen a jövőben technológiákkal, ezen belül is elsősorban a mesterséges intelligenciával (MI) kapcsolatos várakozásoknak megfelelően.
Kiemelve néhány területet, a chatbotok (Jonke és Volkwein 2017) és a személyi asszisztensek (Giri 2016) már szignifikáns fogyasztói bázissal bírnak, és közvetlen befolyást gyakorolnak a digitális marketing és az új média változásaira. Emellett a blokklánc technológiának köszönhetően formálódik a fragmentált individuális elérés és biztonsági validálás bármilyen tranzakció esetén (Kumar, 2018). Sőt, a még gyenge mesterséges intelligencia (narrow artificial intelligence, lásd többek között Burgess 2018) egyre inkább optimalizálja a médiafogyasztást vagy a vásárlást mindkét aktor számára. Ezek azok a technológiák, melyek többlépcsős paradigmaváltást eredményeznek a fogyasztási és szolgáltatási kultúrában - az egyre mélyülő személyre szabottságtól a prediktív tervezésig.

A fentieknek köszönhetöen a digitális marketing és az új média egyre változatosabb képet mutat, $\mathrm{s}$ kérdés, hogy a digitális marketing mennyiben tartja meg erős technológia-orientált és mérhető viszszacsatolásokra fókuszáló irányát - automatizálva számos, ma még kreatívnak tekintett kommunikációs folyamatot, illetve az új média mennyire tudja megőrizni szélesebb társadalmi-kulturális fókuszát. A közös metszetben található kutatások száma és növekedésének hiánya az elmúlt években inkább széthúzást jelez elöre, mint összetartást.

Együtt vizsgálva az interdiszciplínát, alapvetően adatvezérlésröl és tartalomdisztribúcióról beszélünk (Corcoran 2009), ahol a saját, a fizetett és a szerzett média nő össze egymással (többek között Holloman 2012). A saját médiaként létrehozott design és tartalmak felett teljes kontroll gyakorolható, a fizetett média is befolyásolható üzenetrendszert hordoz, míg a szerzett média a közösségi médiában, az értékelésekkel és más funkciókkal hitelesít vagy rombol reputációt. Mindhárom alkalmazás épít a fősodor médiára (mainstream media=MSM), a közösségi hálózatokra (social network sites=SNS), valamint a virtuális és augmentált szolgáltatásoknak együttesen köszönhető kevert valóságokra (mixed realities $=\mathrm{MR}$, lásd többek között: Nedelcheva 2016). Mindeközben a fogyasztó adatosított entitás, $\mathrm{s}$ egyben az érzelmek, élmények, elvárások szövedékében gyakran hoz megalapozatlan és szubjektív döntéseket (Piskóti 2016) vagy hagyatkozik pusztán a technológia prediktív logikájára és követi a specifikus perszónákon alapuló, illetve perszonalizált ajánlásokat (Hagerty 2016). A fogyasztói döntések innentől kiszervezhetők vagy delegálhatók.

A fogyasztót így élményúton (customer journey, többek között Visuri és szerzőtársai 2017), vezeti (végig) a szolgáltató, miközben a vonatkozó tapasztalatok egyre több időszaka és élménye mérhetővé 
válik a szolgáltatás előtt, közben és után is (Voorhees és szerzőtársai 2017). A cél, hogy a fogyasztói útvonalat elkötelezés és érzékenyítés kísérje, illetve értékek (Rekettye 2018) és infotainment (Papp-Váry 2014) kapcsolódjon hozzá - felépítve a fogyasztói lojalitást és lehetőség teremtve a mérésen túl az insightra is (Törőcsik 2011). A fogyasztói élményutat és az elkötelezést építő vizsgálatok számára három terület mindenképpen kihívást jelent. Egyfelöl a preferenciák és korábbi digitális lábnyomok alapján szüröbuborékok jönnek létre (Pariser 2012). Minden fogyasztóé eltérö, az információs tér emiatt leszükül és egyes szürőbuborékok nem vagy kevéssé átjárhatók. Ez nem kedvez a komparatív vizsgálatoknak, miközben kedvez a szolgáltatások személyre szabásának.

Másfelől az álhírek és a félrevezető tartalmak a befolyásolás újabb, technológia-alapú megoldásait hívják elő, ami az elköteleződés vagy bizalomépítés kontextusában számos területet érint (Boczkowski és Anderson 2017, Fehér 2016b). A fogyasztót ez abba az irányba tereli, hogy ellenőrizze és megkérdőjelezze forrásait, s csak ezután alkosson véleményt vagy hozzon döntéseket. Ehhez különböző kutatások adnak ajánlásokat a nyelvészettől (többek között Veszelszki 2017) a politológiáig (többek között Allcott és Gentzkow 2017).

Végül, de nem utolsó sorban a kontextus-alapú fogyasztói és szolgáltatói kommunikáció (Todorovic és Bakir 2016), illetve a digitális platformok mentén fragmentálódó mikroidőben mérhető aktivitások (Grossberg 2016) jelentenek kihívást. Részletezve a kontextus-alapú logikát, a kultúra, az előzetes tapasztalatok, a globalizációban széles körben látható konkurencia-ajánlatok, az élethelyzet vagy egy konkrét "itt és most" szituáció is lehet kontextust definiáló tényező. Lényege, hogy a résztvevők céljaik és elvárásaik szerint határozzák meg a lehetséges kimeneteket, avagy sodródjanak a kiszervezett döntések mentén.

További két terület már részben túlmutat a jövőorientált modellen, részben még szerves része annak. Az első leginkább filozófiai igényü felvetés, mely szerint az új média vagy terjeszkedik, vagy eltűnőben van. Jenkins és szerzőtársai szerint ugyanis a média egyre inkább szétszóródik (2013), Carillo és munkatársai megfogalmazásában pedig mindenütt jelenlévővé válik (2017). Deuze (2016) megközelítésében viszont leginkább úgy terjeszkedik, hogy végül és éppen ezért eltünik mint önmagában azonosítható jelenség és gyakorlat. Ezen megközelítés szerint a mediatizált környezet annyira áthatja a társadalmat, a kultúrát és a gazdaságot, hogy mindeközben mint eszköz láthatatlanná válik.

A második megközelítés a digitális marketing kutatási és mérési trendjeit hangsúlyozza, s következő lépcsőként a fogyasztói magatartás DNS (consumer behaviour DNA) fejlesztését irányozza elő. Ennek segítségével a fogyasztók útovanalait pontosan azonosíthaják az algoritmusok, a prediktív elemzések és marketing folyamatok pedig akár teljesen automatizálhatóvá válnak (Takahashi 2019).

Az itt bemutatott, jövőorientált megközelítés kizárólag a legfigyelemreméltóbb megközelítéséket összegezte az első két modell fogalomkészlete és a jellemzően hivatkozott, jövőorintált szakirodalom alapján. A szinergiát feltételező eredmény egy fogyasztói magatartás DNS-en és szolgáltatón alapuló, a marketing- és médiatechnológiával támogatott célrendszer, melyben az automatizált megoldások mellett egyre nagyobb szerep jut a szofisztikált tartalomgenerálásnak és a kezdeti, de máris komplex ökoszisztémát építő MI-folyamatoknak (lásd az összegzést a 4. ábrán). 


\section{4. ábra. A digitális marketing és az új média jövőorientált összefoglaló "szem” modellje}

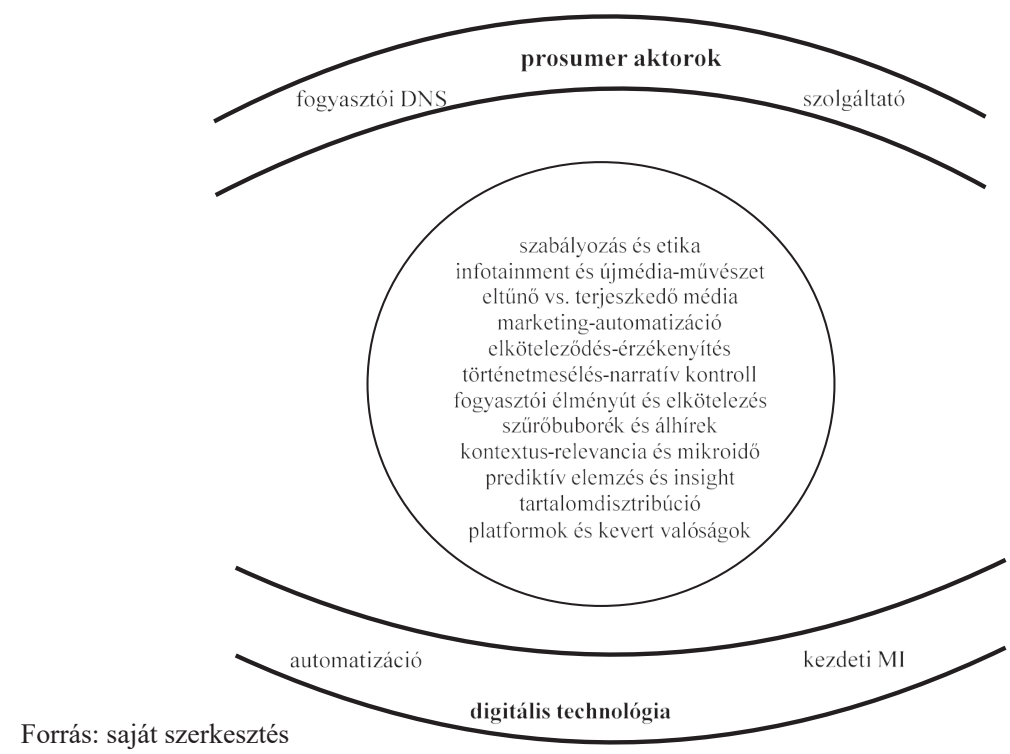

\section{ÖSSZEFOGLALÁS ÉS AJÁNLÁSOK}

A fenti szinergia-alapú modellfejlesztő tanulmány célja volt röviden összefoglalni a föbb, átfedő és eltérő témaköröket a digitális marketing és az új média tudományos és kutatási trendjeiről. A fentiek alapján több területen is nézőpont-közelítés érhető tetten a két diszciplínában, ami közös gyakorlatra és vizsgálatra ad lehetőséget interdiszciplináris keretben. Az átfedések és a szerteágazó tématerületek ellenére viszonylag alacsony számú a jelenleg elérhető, közös fókuszú kutatás és tanulmány, ami jelentős feltárandó területre mutat rá. Emellett egyes terminológiák és trendtémák, mint például a hatékonyság és a hatásosság, avagy a történetmesélés és narratíva, további közelítésre adnak lehetöséget.

Különösen érvényes a közelítés fontossága a feltörekvő technológiák esetén, melyek fokozatosan átírják a kommunikáció és a fogyasztóiszolgáltatói interakció egyes minőségeit. Ezt a megközelítést erőteljesen aláhuzza az informatikai és mérnöki tudományok egyre intenzívebb jelenléte a digitális marketing és az új média kutatásában egyaránt. Emellett interdiszciplináris keretben érdemes megvizsgálni a mindenütt jelen lévő és az eltűnő média kérdéskörét, valamint a digitális marketing automatizációját és konvertálását a korai mesterséges intelligencia rendszerekbe.

A fenti gondolatmenet szándéka szerint alapot ad az egyre több területtel és elágazással bíró témák lehorgonyzásához és a mélyebb elemzésekhez túlmutatva azon a "buzzword" logikán, melyet a szakmai gyakorlat, s ennek köszönhetöen gyakran a tudomány is diktál - sodródva különböző várakozásokkal. A komparatív kutatási dimenzió és a közelítő interpretáció támogatja az évente megjelenő vagy néhány évre előre prognosztizált hívószavak létjogosultságát vagy azok hiányát, s bizonyos értelemben megóvhatja a két szakterületet a gyors diskurzus-avulástól.

Összességében a következö ajánlások fogalmazhatók meg:

- Az első modell alapján a szolgáltatói és fogyasztói szerepek vizsgálata elsődleges olyan technológia-alapú, de tartalmakra épülö kommunikációs csatornák mentén, melyek együttesen facilitálják a továbblépést a digitális marketing és az újmédia-alkalmazások számára.

- A második szinergia-modellre hivatkozva javasolt közelíteni egyes terminológiákat, illetve az egyre inkább technológiai alapú digitális marketing számára fontos 
erőforrás az új média társadalmi-kulturális logikája - és vice versa.

- A harmadik, jövőorientált modell alapján egymáshoz képest érdemes újradefiniálni az új média kiterjedt szerepét és a digitális marketing feltörekvő automatizációs trendjeit, kiaknázva a közös erőforrások lehetőségeit a mesterséges intelligencia megfelelö tréneléséhez.

\section{HIVATKOZÁSOK}

Allcott, H., Gentzkow, M. (2017), "Social Media and Fake News in the 2016 Election" Journal of Economic Perspectives, 31 2, 211-36 DOI: 10.1257/jep.31.2.211

Boczkowski, P. J. and Anderson, C. W. (2017), Remaking the News. Cambridge: The MIT Press.

Burgess, A. (2018), The Executive Guide to Artifcial Intelligence, London: Palgrave Macmillan. DOI: 10.1007/978-3-319-63820-1

Burns, K. S. (2016), "How the top social media brands use influencer and brand advocacy campaigns to engage fans", in: Hutchhins, A. L. and Tindal, N. T. J. (eds), Public Relations and Participatory Culture: Fandom, Social Media and community engagement, NY: Routledge. DOI: 10.4324/9781315766201

Carillo, K., Scornavacca, E. and Za, S. (2017), The role of media dependency in predicting continuance intention to use ubiquitous media systems. Information Management 54 3, 317-335. DOI: 0.1016/j.im.2016.09.002

Deuze, M. (2016), "Presentation about the new media at AllWeb in Skopje as a professor of University of Amsterdam", Link: https://www. youtube.com/watch?v=PALyd_V1T7o

Fehér K. (2016a), Digitalizáció és új média. Trendek, stratégiák, illusztrációk, Budapest: Akadémiai Kiadó

Fehér K. (2016b), “Online elköteleződés az automatizált és kollaboratív játékosító trendekben”, Jel-Kép, 5 4, 3-16. DOI: 10.20520/JELKEP.2016.4.3

Fehér, K. (2017), "NetFrameWork and the Digitalized-Mediatized Self', Corvinus Journal of Sociology and Social Policy, 8 1, 111-26 DOI: 10.14267/CJSSP.2017.01.06

Flew, T. (2014), New media. An introduction, 4/e. Oxford University Press

Cisco Systmes Inc. (2019) Cisco Visual Networking Index: Forecast and Trends, 2017-2022 White Paper. Updated: February 27, 2019. Link: https:/www.cisco.com/c/en/us/solutions/collateral/service-provider/visual-networking-index-vni/white-paper-c11-741490.html

Corcoran, S. by Forrester (2009), Defining earned, owned and paid media. Online: http://blogs. forrester.com/interactive_marketing/2009/12/ defining-earned-owned-and-paid-media.html

Giri, A. V. (2016), "The role and impact of e-commerce on consumer behaviour", Economic and Social Development: Book of Proceedings, 
Varazdin: Varazdin Development and Entrepreneurship Agency. 390-400

Grossberg, A. K. (2016), "The new marketing solutions that will drive strategy implementation", Strategy \& Leadership, 44 3, 20-6 DOI: 10.1108/SL-04-2016-0018

Hagerty, J. (2016), 2017 Planning Guide for Data and Analytics. Link: https://www.gartner.com/ binaries/content/assets/events/keywords/catalyst/catus8/2017_planning_guide_for_data_ analytics.pdf

Holloman, C. (2012), The social media MBA. Hoboken, NJ: Wiley. DOI: 10.1002/9781119208310

Hughes, T. P. (1994), "Technological momentum", in: Marx, L. and Smith, M. R. (eds.), Does technology drive history? The dilemma of technological determinism, Cambridge, MA: The MIT Press, 101-13

Jenkins, H. (2010), Transmedia Storytelling and Entertainment: An annotated syllabus. Continuum, 24 6, 943-958. DOI: $10.1080 / 10304312.2010 .510599$

Jenkins, H., Ford, S., Green, J. (2013), Spreadable media. Creating Value and Meaning in a Networked Culture, New York: NYU Press

Jonke, A. W. and Volkwein, J. B. (2017), "From Tweet to Chatbot - Content Management as a Core Competency for the Digital Evolution", in: Linnhoff-Popien, C., Schneider, R. and Zaddach, M. (eds) Digital Marketplaces Unleashed, Springer, 275-85 DOI: 10.1007/978-3-66249275-8

Kraidy, M. M. (2013), "The body as medium in the digital age: challenges and opportunities", Communication and Critical/Cultural Studies, 102-3, 285-90 DOI: 10.1080/14791420.2013.815526

Kumar, V. (2018), "Transformative Marketing: The Next 20 Years", Journal of Marketing, 82 4, 1-12 DOI: $10.1509 / \mathrm{jm} .82 .41$

Launchmterics (2019) Influencer Campaign Management. Link: https://www.launchmetrics.com

Lister, M., Dovey, J., Giddings, S., Grant, I. and Kelly, K. (2009), New Media: A critical introduction, New York: Routledge.

Manovich, L. (2001), The Language of New Media, Cambridge, MA: MIT Press

McLuhan, M. (1964), Understanding Media: The extensions of man, New York: McGraw Hill

Nedelcheva, I. (2016), "Analysis of Transmedia Storytelling in Pokemon GO", International Journal of Humanities and Social Science, 10 11, 3690-3698. DOI: 10.5281/zenodo. 1128275

Negroponte, N. (2004), Digitális létezés. Budapest: Typotex
Papp-Váry, Á. (2014), Márkázott szórakoztatás, Budapest: Akadémiai Kiadó

Pariser, E. (2012), The filter bubble, New York: Penguin Press

Piskóti, I. (2016), “A business marketing identitása - elmélet, kutatási trenek, az innováció- vezérelt modell", Vezetéstudomány, 47 4, 35-44

Rekettye, G. (2018), Értékteremtés 4.0, Budapest. Akadémiai Kiadó

Ryan, D. (2017), Understanding Digital Marketing: Marketing Strategies for Engaging the Digital Generation, London: Kogan Page

Shannon, C. E., Weaver, W. (1949), The mathematical theory of communication, Urbana, IL: University of Illinois Press

Takahashi, J. (2019), "Consumer Behavior DNA for Realizing Flexible Digital Marketing", Fujitsu Scientific \& Technical Journal, 55 1, 27-31

Todorovic, M., Bakir, A. (2016), Rethinking Strategy for Creative Industries: Innovation and Interaction, Abingdon: Routledge

Töröcsik M. (2011), Fogyasztói magatartás. Insight, trendek, vásárlók, Budapest: Akadémiai Kiadó

Veres Z. (2009), A szolgáltatásmarketing alapkönyve, Budapest: Akadémiai Kiadó

Visuri, A., Hosio, S., Ferreira, D. (2017), E"xploring mobile ad formats to increase brand recollection and enhance user experience", in: MUM '17 Proceedings of the 16th International Conference on Mobile and Ubiquitous Multimedia. Stuttgart, November 16-19 311-319. DOI: $10.1145 / 3152832.3152834$

Veszelszki, Á. (2017), "Linguistic and non-linguistic elements in detecting (Hungarian) fake news", Acta Universitatis Sapientiae Communicatio, 4 1, 7-35. DOI: 10.1515/auscom-2017-0001

Voorhees, C. M., Fombelle, P. W., Gregorie, Y., Bone, S., Gustafsson, A., Sousa, R., Walkowiak, T. (2017), "Service encounters, experiences and the customer journey: Defining the field and a call to expand our lens", Journal of Business Research, 79 October, 269-80 DOI: 10.1016/j. jbusres.2017.04.014

Zelenkauskaite, A. (2017), Remediation, convergence, and big data: Conceptual limits of cross-platform social media. Convergence, $\mathbf{2 3}$ 5, 512-527. DOI: $10.1177 / 1354856516631519$ 
Fehér Katalin PhD, tudományos fömunkatárs

Budapesti Gazdasági Egyetem feher.katalin@uni-bge.hu

\section{New media and digital marketing: synergy models and recommendations for convergence of the two disciplines}

\section{THE AIMS OF THE PAPER}

First and foremost, the goal is to develop usable synergy models in practice and theory by analysing scientific and research trends of new media and digital marketing. The reason behind this goal is the relatively small number of available international publications and research projects in the intersection comparing the versatile possibilities of discourse-approach and forecasting.

\section{METHODOLOGY}

The study is built on three pillars. The first one provides a literature review about the framework of digital technology based on the fundamental interdisciplinary sources. The second one filters and summarises the relevant academic trends applying standard scientific and research databases. The last one presents a future vision by the first two synergy models and the emerging trends.

\section{MOST IMPORTANT RESULTS}

New media as an extensive and comprehensive socio-cultural interpretative framework, and the research fields of the more specific digital marketing have strong synergies. As an interdisciplinary field, some of their research projects are inseparable and would be interpreted as a resource for each other. The first model emphasises the role of the modest approach of technological determinism. The second one highlights the already unavoidable digital marketing fields and new media context - via their intersection, and also, via their different approaches. The third model provides a future vision by the emerging technological trends and their consequences regarding the synergy of the two disciplines.

\section{RECOMMENDATIONS}

The paper outlines the importance of synergies for research studies and for professional projects based on the models briefly described above.

Keywords: new media, digital marketing, automation, prosumer actors, consumer behaviour DNA, narrow AI 



\title{
A mesterséges intelligencia árazásbeli alkalmazásának várható hatásai
}

\author{
Danyi Pál \\ Budapesti Műszaki és Gazdaságtudományi Egyetem
}

\begin{abstract}
A TANULMÁNY CÉLJA
A mesterséges intelligencia (MI) technológiája, eszközei egyre több üzleti területen fognak elterjedni a közeljövőben, köztük a marketing és árazás szakterületein is. Célunk annak bemutatása, hogy az MI, és rajta keresztül az adatvezérelt megközelítések milyen hatással lesznek az árazásra, hogyan fogják újraírni a vállalatok jelenlegi árazási gyakorlatát.
\end{abstract}

\section{ALKALMAZOTT MÓDSZERTAN}

A koncepcionális tanulmányomban a korábbi részletes szekunder kutatásomon alapulva vizsgáltam meg a MI módszerek várható hatását. A kutatásom végigtekinti az árazás legfontosabb folyamati elemeit.

\footnotetext{
A KUTATÁS LEGFONTOSABB EREDMÉNYE

Kutatásomban bizonyítom, hogy az adatvezérelt, MI eszközökkel támogatott technológiák alapvető változásokat hoznak az árazásban a következő évtizedben. Kidolgoztam az optimális ár megállapításának egy lehetséges MI-alapú folyamatát. Javaslatot teszek az egydimenziós termékár három dimenzióra kiterjesztésére, ahol az idő és vásárló dimenziók is megjelennek.
}

\section{ÚJDONSÁGOK; GYAKORLATI JAVASLATOK}

Az értékalapú és dinamikus árazás nagymértékben el fog terjedni az MI-nek köszönhetően. A rezervációs ár, az árrugalmasság, és az optimális ár olyan mikroökonómiai elméleti fogalmak, amelyek az MI alkalmazásával gyakorlati jelentőségúvé válnak a marketingben: lehetséges lesz szinte bármilyen cég számára kiszámítani ezeket sokkal pontosabban, mint jelenleg, és ezáltal jelentősen növelni a profitot.

Kulcsszavak: mesterséges intelligencia, intelligens árazás, dinamikus árazás, gépi tanulás, adatvezérelt, optimális ár, személyre szabott ár 


\section{BEVEZETÉS}

A negyedik ipari forradalom drasztikus változásokat fog hozni nem csak a termelésben, hanem az alkalmazott üzleti modellekben is, többek között a marketing és árazási folyamatokban. Ahogy Rekettye (2018) megállapítja, a technológiák alkalmazásának hatására az árképzés határai egymástól távolabb tolódnak, és nagyobb mozgásteret kínálnak az árak alakítására. Jelen tanulmányban kifejezetten a mesterséges intelligencia (továbbiakban: MI) alkalmazásának következményeit vizsgálom a lakossági kereskedelmi árazásra nézve. Egy korábbi cikkemben (Danyi 2018) ismertetett szekunder kutatás eredményei alapján kellő alapanyag áll rendelkezésre, hogy részletesen elemezzem, milyen céljai, eszközei és hatásai lesznek az MI technológiák használatának az árazásban. Hipotézisem, hogy forradalmi változást hoz az MI az árakban és árazásban, mert fontos eszközként sikeresen felhasználható.

\section{AZ MI ALKALMAZÁSÁNAK CÉLJAI}

A lakossági piacon (B2C) az MI módszerek és technológiák árazásban való alkalmazását a kereskedői oldal kezdte el és forszírozza, hiszen náluk áll rendelkezésre a szükséges anyagi erőforrás. A vevői oldal egy ideig biztosan háttérbe fog szorulni, azaz nem lesznek rövid távon olyan automaták, amelyek jelzik, hogy mit, mikor, mennyiért érdemes megvennie a vásárlónak. (A vevői oldalról a 6. fejezetben szólok részletesebben.)

Az eladói oldal legfontosabb célja az MI alkalmazásával az, hogy automatikusan tudjon árakat megállapitani, azaz pontosan meg tudja mondani, hogy mit (terméket, szolgáltatást), kinek (milyen vásárló szegmenseknek, akár egyéni szinten), mikor és meddig, milyen áron kínáljon. Ezen túlmenően az alábbi konkrét célokat is megfogalmazza a kereskedő: az MI-vel

- maximalizálni lehessen a profitot az „optimális” árak meghatározásával; (itt az optimális elméleti fogalom, és a jelentése sem egyértelmü. Értelmezésére a tanulmányban sor kerül.)

- $\quad$ az árazás pontosabb legyen, figyelembe véve az idő és vásárlói igény (mikor és kinek) dimenziókat;

- extraprofitot lehessen elérni azokhoz a versenytársakhoz képest, akik nem alkalmaznak ilyen technológiákat;
- költséget lehessen csökkenteni: pl. automatikus árazó rendszerekkel, árazó robotokkal;

- gyors árazási döntéseket lehessen hozni a változó körülményekre reagálva.

A következökben megvizsgálom, hogy egyáltalán melyik az az MI eszközkészlet, amit fel lehet használni ezen célok eléréséhez.

\section{ESZKÖZÖK AZ ÁRAZÁSBAN}

Az MI oldaláról megközelítve három fő technológia-típus játszik kiemelkedő szerepet az árazásban, amelyek a Danyi (2018) tanulmány 5. táblázatában szereplö MI területek elemzéséből következnek: (1) gépi tanulás; (2) adatelemzésen, üzleti intelligencián alapuló MI algoritmusok, rendszerek; valamint (3) a kommunikációt újragondoló MI megoldások.

\section{Gépi tanulás}

A feldolgozott irodalmakból látszik, hogy jelenleg a gépi tanulás a legnépszerúbb MI technológia. $\mathrm{Az}$ árazás szakterületen belül a mélytanulás válhat elterjedtté, elsősorban az ármeghatározásra. Mit tanulhat egy árazási gép? Azt, hogy milyen tényezőket kell figyelembe venni és milyen mértékben ahhoz, hogy a megállapított ár a legnagyobb profitot eredményezze a kijelölt időszakra nézve.

A gépi tanulás (mélytanulás) elsősorban a klaszszifikációs és regressziós problémák megoldására kiváló, és sokkal pontosabb eredményeket lehet elérni vele, mint évtizedekkel ezelött. Ez a megközelítés a klasszikus regressziószámítási (matematikai statisztikai) algoritmusok képességeit messze meghaladóan, lényegesen komplexebb problémák megoldására alkalmas, mivel jóval több paramétert (szempontot, dimenziót) lehet figyelembe venni a modellezésnél, mint korábban. Az árazást tekintve tucatnyi, vagy akár több tucat paramétert figyelembe lehet venni mind a kereskedő, mind a vásárló oldaláról. Az MI képes megtanulni, hogy kinek, mit, és mennyiért érdemes kínálni, azaz meghatározható minden egyes termékre és termékkategóriára, hogy milyen áron milyen szegmentációjú ügyfelek lesznek a várható vásárlók. A regresszióval az határozható meg, hogy milyen áron hány vevö várható és mekkora profitot fog a kampány eredményezni meghatározott idöszakon belül. A klasszifikációs modell ennél egyszerübben csak azt vizsgálja, hogy a terméket az adott áron megveszik-e vagy sem.

A gépi tanulás szükséges sikerfeltétele, hogy legyen kellően sok historikus adat, amivel a modell pontossága folyamatosan javítható. 
A visszacsatolásos tanulás esetén azzal az információval tanítjuk a modellt, hogy a termék a kiszámolt áron elkelt-e vagy sem, ill. mennyi idő alatt. Ebből következik, hogy a gépi tanulás alapvetően a lakossági piacon működik, mert a szervezeti (B2B) piacok nagy részén nincs elég tranzakciós adat, kivéve persze a legnagyobb kereskedőket.

A gépi tanuló rendszerek nem kaphatók dobozos termékként, ahhoz még több év fejlesztés szükséges. Ennek oka, hogy a tanuló rendszereknél nagyon sokféle modell (neurális háló architektúra) és beállítási paraméter lehetséges, és nem tudjuk pontosan, hogy az egyes árazási problémákra milyen beállítások a legjobbak. Egyelőre kísérletezni kell a mélytanuló modellekkel, és azokból kihozni a maximumot az ún. hiperparaméterek hangolásával. Általánosan az várható, hogy a következö évtizedben a modellek fognak versenyezni egymással, és előbb-utóbb kialakulnak a legsikeresebb modellek egy-egy konkrét architektúrával, ill. paraméterhalmazzal.

\section{Az adatelemzésen, üzleti intelligencián alapuló MI algoritmusok, rendszerek}

Az árazás tágabb problémakörében nem feltétlenül a gépi tanulás vezet eredményre. Az alábbi területeken különféle MI technikák alkalmazhatók, úgymint döntésmenedzsment, marketing automatizálás, kognitív keresés, robot-alapú folyamat automatizálás (RPA), MI-vel támogatott üzleti intelligencia platform, ill. tartalom létrehozás (Danyi 2018). Röviden kifejtve ezek árazásbeli alkalmazását:

- Árfigyelés és árfelismerés: a képi és videó tartalmakban, hirdetésekben, reklámokban megjelenő árak gyors felismerése már MI technológiákat követel.

- Intelligens árösszehasonlítás: a termék megszerzésének teljes várható költségének kiszámítása, beleértve a szállítást, a garanciát, stb. Az MI megoldások segítenek kiválasztani azt a kereskedőt is, ahol a legjobb vásárlási élményt kaphatja a vásárló.

- $\quad$ Árkedvezmények rendszere: a kereskedők számára az optimális árkedvezmények kialakítása, amelyben felhasználhatók a gépi tanulás eszközei is.

- Árazási folyamat automatizálása: a teljes értékesítési folyamat kézbentartása, folyamatos fejlesztése nagyon komplex emberi tevékenység, amelynek során automatizálni lehet MI eszközök (pl. robot-alapú folyamatautomatizálás, megfelelőség, felhő robotika) segítségével, hogy milyen forrásokból milyen adatokat használjon az árazógép és az ár hol jelenjen meg, pl. online webáruházban, hirdetésben, vagy éppen utcai megállító táblán.

- Árazási szakértő rendszerek: az árazás a számokon, számításokon túl számos szabály, fogalom, tudáselem megfelelő alkalmazását is jelenti, beleértve az árazási stratégiát, árpszichológiát, jogszabályok közötti eligazodást.

- Árjegyzékek, katalógusok automatizált létrehozása, karbantartása: MI eszközök felhasználása hibák, inkonzisztens árazások kimutatására. Az árjegyzékek rendszeres, sőt folyamatos megújítása szintén támogatható, helyettesíthető automatikus eszközökkel.

\section{A kommunikációt újragondoló $\mathrm{MI}$ megoldások}

Egészen újszerü az a megközelítés az árazásban, ami a több évezredes hagyományos adás-vételi gyakorlatot, az alkudozást gépesíti. A kereskedői oldalon az MI által müködtetett alkudozógép tudni fogja, hogy meddig mehet el a kedvezményekben. Az ember-gép kommunikációnak ezen a területein (pl. chatbotok, érzelemfelismerés, biometrika, számítógépes látás és képfelismerés) a határ az ember teljes helyettesítése: a gép figyelheti a vásárló reakcióit, metakommunikációját, akár arcmimikáját. A jövőben a gép tökéletesen ki fogja ismerni a vásárlót abban, hogy meg akarja-e venni a terméket vagy sem az adott áron, van-e értelme még tovább alkudozni, természetesen nagyszámú esetet elemezve. Valószínúsíthető, hogy a gép meg fogja tudni határozni a vevő rezervációs árát, azaz azt a legmagasabb összeget, amiért még hajlandó megvenni az ügyfél a terméket.

A robotizált személyes asszisztens (pl. Amazon Echo, Google Home) egy fontos változata lesz a jövőben a vásárló asszisztens, amely szól, ha valami jó akciót talált. Ehhez persze meg kell tanulnia a gazdája preferenciáit, illetve ismernie kell a rendszeresen felmerülő vásárlási rutinok mellett az egyedi igényeket is. Speciális változatban ingatlanra, autókra, utazásra szóló ,akcióvadász” MI rendszerek is meg fognak jelenni. 


\section{AZ MI HATÁSA AZ ÁRAZÁSRA}

Noha az előzőekben ismertetett MI alkalmazások egy része futurisztikusnak tünhet, azok nagy többsége minden bizonnyal meg fog valósulni a következő egy-két évtizedben. mert ezekre az alkalmazásokra szükség lesz akár a kereskedői, akár a vásárlói oldalon. A következőkben megvizsgáljuk, hogy mindezen MI alkalmazások milyen változást hoznak, várhatóan milyen hatásuk lesz az árazási folyamatra, ill. az egész vásárlási tevékenységünkre, szokásainkra (1. ábra).

\section{1. ábra: Az MI várható hatásai az árazásra}

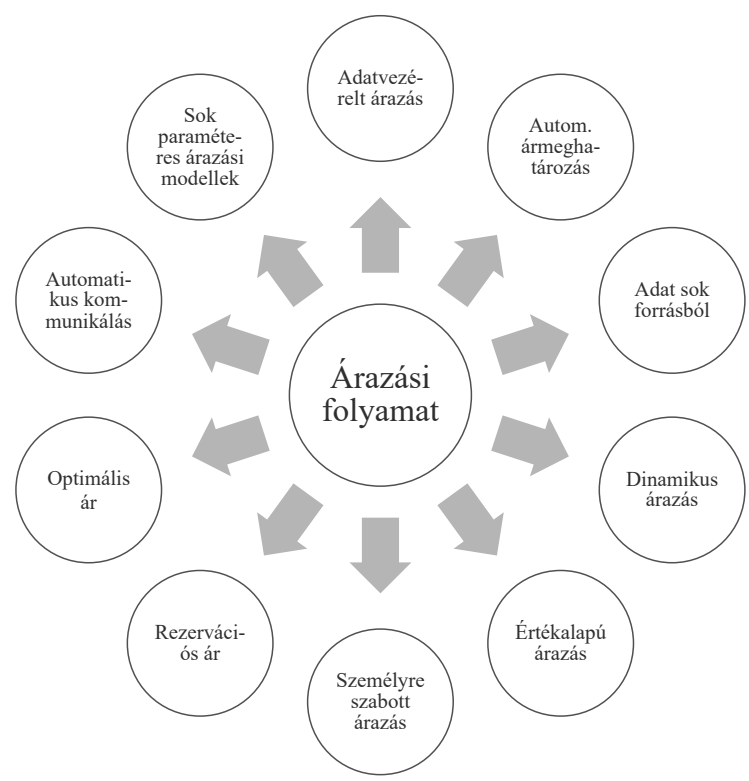

Forrás: saját szerkesztés

\section{Árazási folyamat}

$\mathrm{Az}$ árazási folyamat, akár az értékesítési, akár a marketing vállalati folyamat részeként várhatóan jelentősen megváltozik az MI eszközök bevezetésének hatására:

- Egyre fontosabb lesz az adatelemzés felhasználása, és adattudósok alkalmazása az árazásban. A jelenleginél sokkal több adatot kell majd begyüjteni.

- A következő évtizedben a modellek, algoritmusok fognak versenyezni egymással (mint ahogy a gépi tanulás különböző módszereinél, paraméterezéseinél látható manapság is).

- Azármeghatározás folyamata automatikus szabályozási folyamattá válik, amelyben minden tranzakció (általános értelemben véve minden ERP és CRM tranzakció, tehát a vevői érdeklődéstől kezdve az eladáson át az utókövetésig) adatai visszacsatolódnak az elemző rendszerbe, amiből az árazó motor automatikusan módosítja az árakat.

- Az árak előzetes meghatározása nem feltétlenül egy konkrét árcímkét jelent majd, hanem egy intervallumot, amelyen belül a gép a vásárlónak egyéni kedvezményt adhat, vagy a vevő alkudozással befolyásolhatja a végső ár kialakítását. Az árazási folyamatot tehát fel kell készíteni arra, hogy nagyobb teret adjon az interaktív árkialakításnak.

Az árazás marketingen belüli szerepe jelentősen változni fog: ahogy a keresletet nem csupán az árak határozzák meg, hanem a marketing mix (4P) többi eleme is, úgy az MI eszközök jól 
használhatók annak meghatározására, hogy az árazás milyen összefüggésben áll a mix további elemeivel. Sokkal szorosabban kapcsolódni fog az árazás a hirdetésekhez, a csatorna megválasztásához, magához a termék vagy kosár ajánlásához is. Évtizedekre munkát fog adni a marketingeseknek, hogy megfejtsék, milyen hatással van a termékre, a helyre és a promócióra, ha az árakat csökkentjük vagy növeljük, és fordítva: milyen módon kell átstrukturálni a termékeket, a csatornákat, vagy az ügyfélszegmenseket, hogy árakat tudjunk emelni és növelhessük a profitot. Csak a marketing-mix integrált, holisztikus megközelítésével lehet megcélozni annak a kereskedői végső célnak az elérését, hogy annak kínáljuk a terméket, akit érdekel, akkor, amikor érdeklődik, és annyiért, amennyiért megveszi.

\section{Adatvezérelt árazás: adatok elemzése számos forrásból}

Az adatvezérelt árazás szükséges feltétele a nagy mennyiségü adat, amit számos forrásból kell majd begyüjtenie a közeljövő kereskedőjének. Az alábbi táblázat szerint három forrásba soroltam az adatforrásokat: (a) saját üzleti müködésben létrejövő és elérhető adatok, (b) más kereskedők, piaci szereplők elérhető adatai, (c) a vevők viselkedéséből származó és származtatható adatok.

\section{1. táblázat: A kereskedők három fő adatforrása az adatvezérelt árazáshoz}

\begin{tabular}{|c|c|c|c|}
\hline Adatforrások: & Saját & Piaci & Vevői \\
\hline $\begin{array}{c}\text { Kereskedó árazási } \\
\text { célja: mit, mikor } \\
\text { mennyiért érdemes } \\
\text { kínálni. }\end{array}$ & $\begin{array}{c}\text { Saját költségek és érté- } \\
\text { kesítési számok alapján } \\
\text { árlimitek meghatáro- } \\
\text { zása. }\end{array}$ & $\begin{array}{c}\text { Más kereskedők figye- } \\
\text { lése (versenytárs árak). } \\
\text { Iparági elemzések. }\end{array}$ & $\begin{array}{c}\text { Vevőviselkedés elem- Kereslet figyelése. } \\
\text { Személyre szabott } \\
\text { árazás. Rezervációs ár } \\
\text { meghatározása. }\end{array}$ \\
\hline
\end{tabular}

Forrás: saját szerkesztés

Az adatok gyüjtése, tisztítása, előkészítése, majd a feldolgozása költséges, időigényes folyamat. A hagyományos tranzakciós adatokon túl szükség lesz egyéb nem-strukturált adatok felhasználására is közösségi oldalakról, videó oldalakról, kommentekből, stb. Az ehhez szükséges szakértelmet is új, még ritka, és igen keresett szakemberek tudják csak biztosítani, mint például adattudósok, vagy az adatvagyon gazdálkodási vezető (Chief Data Officer).

A GDPR rendelkezések jogszabályi feltételei nem tiltják a vásárlói adatok gyüjtését, de azokhoz vásárlói hozzájárulás szükséges. A kereskedők várhatóan kedvezményekkel, ajándékokkal, törzsvásárlói elönyökkel fogják bátorítani az ügyfeleket a hozzájárulás megkötésére. A nem rendelkező ügyfelek anonim elemzése, profilírozása pedig változatlanul lehetséges lesz.

\section{Dinamikus árazás}

A dinamikus árazást kereslet-kínálat alapú árazásnak is tekinti a szakirodalom. Den Boer (2015) szerint az optimális ár meghatározását jelenti olyan esetekben, amikor az árak könnyen és gyakran változtathatók. Rekettye és Liu $(2018,169)$ értelmezésében a vevők árelfogadási hajlandósága (várható kereslet) és a rendelkezésre álló termékvolumenek, kapacitások (kínálat) pillanatnyi állapotából levezethető hozammenedzselésként érthetjük, azaz minden időpillanatra megállapítható az az ár, amellyel a vállalkozás maximalizálja a profitját.

Noha a dinamikus árazás közel 40 éve használatos gyakorlat, a bonyolult számítási modellek és a korlátos számítógépes kapacitások miatt csak az utóbbi 10-15 évben kezdett elterjedni, föleg a turizmus területén. Semmiképp nem mondható, hogy a dinamikus árazásnak szükséges feltétele lenne a MI, hiszen anélkül is sok területen számíthatók a kereslet-kínálati egyensúlyok. Két lépésben viszont jól felhasználható az MI: egyrészt a várható kereslet előrejelzésében, másrészt annak a függvénynek az algoritmizálásában, amelyik 
előállítja a javasolt árat a tényleges és várható kereslet különbségéből, valamint a kínálati adatokból (2. ábra). Ennek során az MI megközelí tések (főleg a gépi tanulás, azon belül a mélytanulás) lehetővé teszik az egyre több paramétert tekintetbe vevő modellek szerinti számítást, egyre pontosabb árakat megállapítva, egyre növelve a profitot.

\section{2. ábra: Az MI jól felhasználható a várható kereslet előrejelzésében a dinamikus árazás során}

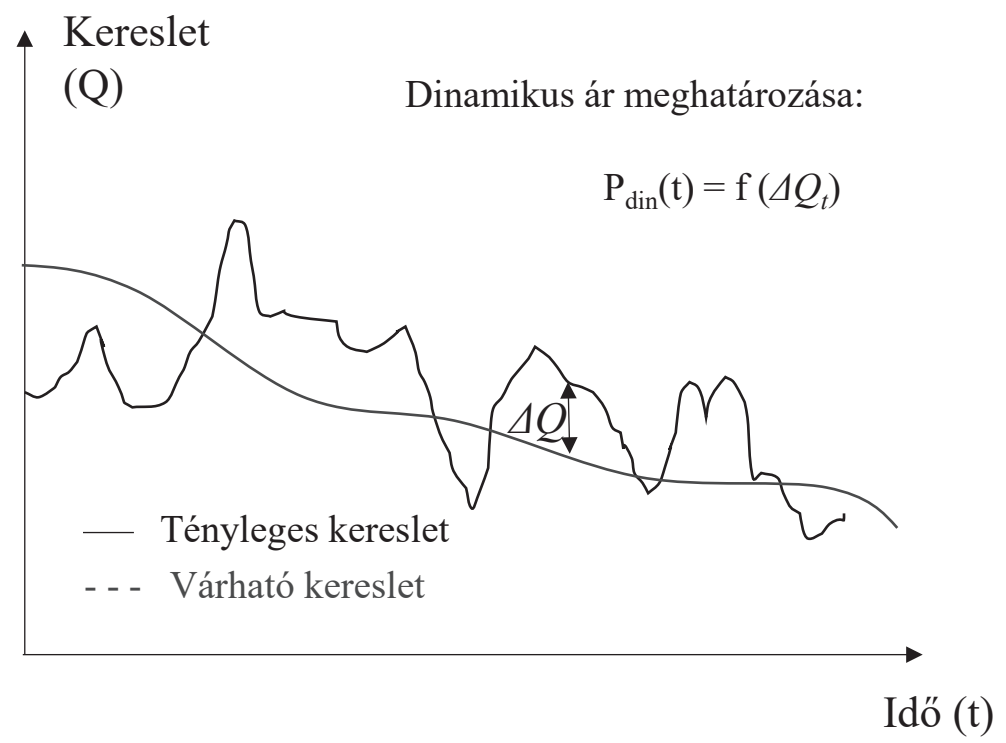

Forrás: saját szerkesztés

Várható tehát, hogy az MI térhóditásával a dinamikus árazás egyre jobban elterjed a turizmuson kívül is minden olyan esetben, ahol a kereslet és kínálat pillanatnyi értékei szerinti árazás alkalmazható és a vásárlói oldalon elfogadható. (Az etikai kérdéseket terjedelmi korlátok miatt nem érintjük.) A mozik, színházak, fesztiválok, sportesemények jegyeinek árazása részben már dinamizálódott az elmúlt években (és több országban elindultak ez irányú kísérletek), csakúgy mint az energia ára: az aktuális felhasználás megszabja az árakat. Manapság jellemzően azokon a területeken népszerü, ahol a kínálat korlátos, vagy nehezen bővíthető.

\section{Értékalapú árazás}

Az értékalapú árazás lényege, hogy „,a fogyasztók vásárlási döntésében az érzékelt, észlelt vagy elfogadott érték játszik döntő szerepet: ez az, ami a vásárlási hajlandóságot alapvetően meghatározza." (Rekettye 2012) Az észlelt érték szerinti árképzés az elmúlt két évtized legnépszerübb elmélete az árazási szakirodalomban. Ugyanakkor a gyakorlati terjedésének gátat szab, hogy igen bonyolult módon lehet csak modellezni azt, amit a termék nyújthat a vevőnek. Ráadásul a vevő nem csupán egy árat érzékel és értelmez, hanem azonnal hozzákapcsol egy összetett értéket, röviden hasznosságot a kívánt termékhez. Ha az ár és a hasznosság közel azonos szinten van, akkor megtörténhet a vásárlási tranzakció. Továbbá az is kihívást okoz, hogy minden vásárlószegmens, sőt akár egyénileg is, más-más értéket tulajdonít a terméknek. Ha a kereskedő nem vesz tudomást a vásárlók értékelési eltéréseiről, akkor ugyancsak profitot veszít. Az értékalapú árazás a megkülönböztető értékről szól. (Macdivitt - Wilkinson 2012, 19). Ezt a termékre, szolgáltatásra, vagy éppen a kereskedőre vonatkozó megkülönböztető értéket kell meghatározni és mérni, aminek alapján árazni lehet majd.

Az MI alkalmazásával ezek a fogalmak (érték, hasznosság, vásárlási hajlandóság) pontosabban 
mérhetővé válnak, így az értékalapú árazás gyakorlata jelentősen kibővülhet. MI-vel egyrészt előre jelezhető, hogy jelenleg mekkora hasznosságot érzékel a vevő, és ennek alapján a szükséges hirdetés, reklámozás is megbecsülhető, azaz annak mértéke, hogy mennyivel kell növelni az észlelt értéket az érdeklődést felkeltéséhez és a vásárlási hajlandóság megszületéséhez. A vásárlási igény felkelthető pl. az ún. rezervációs árral, vagy annál alacsonyabb „visszautasíthatatlan” árral. A termék hasznossága szubjektív a vásárló számára, éppen ezért a vásárlás számos érzelmi, irracionális elemet is tartalmaz. Az MI eszközökkel egyre több ilyen szubjektív elem érvényesíthető az értékszámítás során, például a vevő olyan igényei is, mint a divatkövetés, a „barátnak/szomszédnak már bevált” vagy „Karácsonyra/ ünnepre sürgősen kell" szempontok.

Ha a kereskedőnek sikerül - MI segítségével a termék várható észlelési értékét, hasznosságát jó közelítéssel megbecsülni, akkor az egyedi vásárló szintjén egy személyre szabott ár is adható, illetve nagy tömegek esetén értékalapú szegmensekbe sorolhatók a vásárlók, nem csak árazás, hanem egyéb marketing célokból is (pl. hirdetés, reklámozás különbözö csatornákon). Az árazógéphez kapcsolt hirdetögép segíteni fog abban, hogy minden ügyfél annyiért lássa a terméket hirdetni (személyre szabottan), amennyiért még éppen hajlandó megvenni, mert megfelelően magas értéket lát benne. Egy gyüjtő például többet hajlandó adni egy ritka könyvért, mint egy átlagember. (Erre a gondolatra épülnek az aukciók.) Példa kedvéért meg kell határozni egy sportcipő árát. Először azonosítani kell azokat a potenciális vevőket, akik akár 30 ezer forintot is megadnának érte, és számukra kell hirdetési kampányt indítani. Utána le lehet szállítani a termék árát 25 ezer forintra, majd harmadik körben 20 ezerre, és közben kampánnyal megcélozni azokat a vevőket, akik számára megér annyit.

Ha jelentős különbség adódik az észlelt érték és a kínált fogyasztói ár között, akkor az MI segítségével olyan kereskedöi döntések is segíthetők lesznek, miszerint plusz értéket kapjon az ügyfél, aminek örül, pl. ingyenes szállítás, kiterjesztett garancia, stb. Olyan win-win helyzeteket képes az MI azonosítani, amelyekben mindkét fél elégedett lesz, és ez kompenzálhatja az MI költségét, hiszen egyébként az ügyfél nem vette volna meg a terméket. Az árpszichológia is jelentős fejlődés előtt áll: MI módszerekkel befolyásolható lesz a vevő (akár tudat alatt), hogy mennyire tartson hasznosnak egy terméket, vagy mikor vegye meg, milyen feltételekkel.

Az érték és hasznosság mérésének alapfeltétele a vevőkről szerzett széleskörủ adatok, információk elemzése, tehát a kereskedőnek rendelkeznie kell megfelelő mennyiségü és minőségü adattal az ügyfeleiről. A jelenlegi gyakorlat szerint csak a törzsvásárlókról vannak adatok, de azok elemzése sem történik meg rendszeresen, és igen kevés célra használják az elemzés eredményeit. Az MI terjedésével valószínüsíthető, hogy a legkülönfélébb vásárlói adatok gyüjtése és kiértékelése fog megtörténni, amit néhány példával illusztrálunk:

- Milyen komoly a vevő vásárlási szándéka? Ha sok oldalt megnézett, kutakodik az interneten, akkor bizonyára fontos neki a téma és vásárolni akar.

- Mennyire szakértője a termékcsoportnak, ismerője a helyettesítö termékeknek?

- Mennyire árérzékeny a vevő, mikor és mennyiért vásárol: csak akciósan, vagy mindegy, hogy mikor?

- Milyen gyorsan van szüksége a vevőnek a termékre? Azonnal, holnap, vagy ráér két hét múlva, pl. regionális raktárból ideszállítani?

- Mennyire konkrét típust igényel a termékből? Esetleg más színben? Esetleg kicsit más paraméterrel? És arra tud-e nagyobb kedvezmény adni a kereskedő?

\section{Az „optimális” ár}

Egy konkrét termékre azt az árat tekintjük optimálisnak, amit megváltoztatva csökken a profit egy meghatározott idökereten belül, tehát egy globális maximumot jelent. (A profit számításába beleértjük a kereslet ártól való függését.) Az optimális ár új megközelítést kap az MI világban. Mindeddig az „optimális” meghatározása túlságosan idealizált, elméleti matematikai volt a hétköznapi életben. Mindössze annyit lehetett sejteni, hogy a listaár és a kereskedő számára - valamilyen módon - meghatározott minimálár között van egy mozgástér, ami például lehetővé teszi az akciókat, árkedvezményeket (lásd 3. ábra). A szó szoros értelmében optimális ár sosem lesz elérhető, hiszen az mindig csak egy leszükített kontextusban lesz optimális, a vásárlás világa azonban sosem zárt. A reális célkitüzés a gyakorlatban az lehet, hogy a jelenleginél sokkal jobban megközelítjük a valós vásárlási folyamatot, kevesebb elhanyagolással kell élnünk, azaz egyre több paramétert vehetünk figyelembe a modellünkben. Optimális árként - jelen tanulmányban - tehát a gyakorlati megközelítést, az egyre jobban megközelíthető profitoptimalizálást értjük. 


\section{3. ábra: Az optimális ár a profit maximalizálását ígéri (szemléltető ábra)}

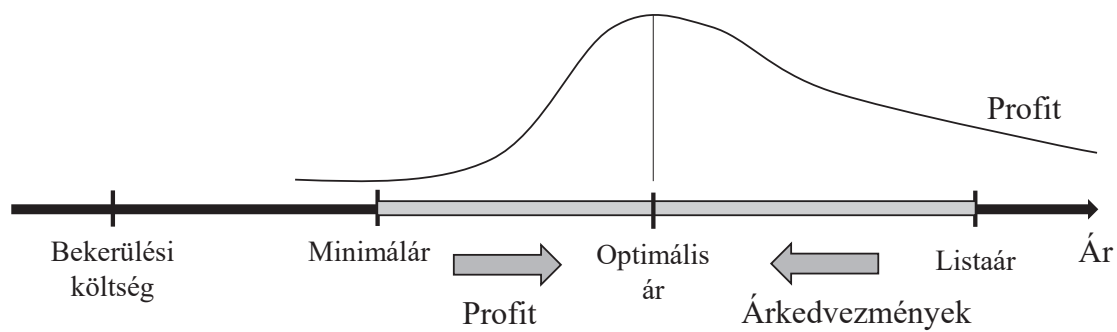

Forrás: saját szerkesztés

Az optimális ár megállapításának jövőbeli, MI által támogatott folyamatára nincs még tudományosan kidolgozott lépéssorozat. A következő fejezetben megkíséreljük egy lehetséges folyamat bemutatásával bizonyítani az MI transzformáló erejét.

\section{AZ OPTIMÁLIS ÁR MEGÁLLA- PÍTÁSÁNAK FOLYAMATA}

$\mathrm{Az}$ egyes termékek optimális árának megállapítása lehetővé válik MI segítségével a következők folyamat szerint, ami egy új, gyakorlati szempontból megvalósítható lépéssorozatot jelent:

1. A vizsgált termék kapcsán kiszámítjuk az árrugalmasságot, ami megmutatja, hogy várhatóan milyen mértékben fog változni a kereslet, ha csökkentjük vagy növeljük az árat.

2. Az árrugalmasság számítást finomítjuk az ügyfeleinkre meghatározott rezervációs ár-becslésekkel.

3. A várható kereslet és a költségeink alapján kiszámítható a várható profit. A maximális profithoz tartozó ár lesz az optimális ár.

4. Az optimális termékár kiterjeszthető két és három dimenzióba is, figyelembe véve az idő és vásárló dimenziókat. Ezzel egy háromdimenziós tér minden egyes pontjához rendelhetünk optimális árat, vagy úgy is mondhatjuk, hogy az optimális áraknak egy háromdimenziós „,elületét" hozhatjuk létre a négydimenziós térben.

5. Szegmensekre, sőt személyre szabottan tudunk árat, sőt optimális árat kínálni, ami a termék általános optimális árától eltérhet.

6. A tényleges eladási számok visszacsatolása alapján módosítjuk a rezervációs árat, az árrugalmassági függvényt, és ennek alapján frissíteni lehet az optimális árakat.

A következőkben részletesen végigtekintjük az egyes lépéseket (az utolsó kivételével).

\section{Az árrugalmasság meghatározása}

Az árrugalmasság, mint az árazás mikroökonómiai alapfogalma, megmutatja, hogy egy termék esetén a fogyasztói árak változtatása milyen függvénykapcsolatban áll a kereslettel. Az árrugalmasság számítása - a kereskedők számára - mindeddig alapvetően elméleti tevékenység volt, mert többféle korlátba ütközött az adatgyüjtés a gyakorlatban: hosszú ideig kellett figyelni egy termék fogyását egy konkrét áron, valamint az árakat is rendszeresen kellett változtatni mindkét irányban. Komoly publikációnak minősült, amikor egy-egy termékre vagy termékcsoportra sikerült „,pontos” adatokat számítani, vagy jól definiált körülmények közötti vásárlások elemzésével közelítő árrugalmasságot megállapítani.Állítom, hogyegyretöbblehetőségünk lesz megbízható árrugalmasságot számítani a következők szerint:

- közvetlenül rendelkezésre állnak nagy tömegủ keresleti adatok, például historikus tranzakciós adatok, amelyekből meghatározható az árrugalmassági függvény,

- tudatosan ,játszanak” a kereskedők az árakkal, és rögzítik, hogy bizonyos árengedmények vagy árnövelések mennyiben hatnak a keresletre,

- egyre több piaci szereplő fog árrugalmasságot számítani globális, nemzetgazdasági, vagy éppen gyártói szinten, amely adatok - valamilyen formában, publikusan vagy elöfizetéssel elérhetők lesznek a kereskedők számára. 
Az így meghatározott árrugalmasság nem az egyes vevőkre szól, hanem a vevők összességének keresletére. A konkrét kereskedelmi tranzakcióban azonban a konkrét vásárló számára kell árat kínálnunk, tehát érdemes az általános árrugalmasságot finomítani a vevőkre vonatkozó információk, például a rezervációs ár felhasználásával.

\section{A rezervációs ár meghatározása}

Az MI-alapú árazógépek várhatóan egyre pontosabban meg tudják majd becsülni a mikroökonómiából jól ismert rezervációs árat, így az eladó megtudhatja, hogy maximum mennyit lennének hajlandók fizetni a vevőjelöltek az aktuális körülmények között. Ez azért is forradalmi, mert a vásárlók többsége nem egy konkrét árlimittel indul vásárolni, és a rezervációs árat legtöbbször maga a vevő sem tudja - részben azért, mert az a vásárlás vagy ártárgyalás folyamán változhat, másrészt olyan tényezőktől függhet, amelyeknek nincs közvetlen köze a tranzakcióhoz (pl. egészségügyi állapot, munkahelyi stressz, boldogságérzet, elöítélet).

A rezervációs árak meghatározásához nincs egyértelmű módszer, de számos lehetőség áll rendelkezésre már most is közelítő számításokat végezni:
- Elsősorban az eddigi vásárlási adatok állnak rendelkezésre, de nem a közvetlen tranzakciós adatok (termék, ár, volumen) lesznek érdekesek, hanem az elemzéssel nyert következtetett adatok: ki, mikor, és milyen körülmények között vásárolt, mennyire árérzékeny, csak akciók, árkedvezmények során vásárol, vagy máskor is, esetleg egyáltalán nem érdekli az ár.

- A „vevői érték” és hasznosság méréseket érdemes lefolytatni, amelyeket az Értékalapú árazás fejezetben már említettünk.

- A már említett alkudozási folyamat elemzése szintén információt jelent az ügyfélről, ami segíti a számítást.

- A kereskedő saját adatbázisa csak a meglévő ügyfelek adatait tartalmazza, de az árösszehasonlító szolgáltatók támpontot tudnak adni a minimálárra, ami sok vevőjelölt számára jelenti a rezervációs árat.

A vevői érdeklődésre nézve (átkattintások) az adatok jellemzően ismertek vagy anonimizáltan megvásárolhatók a szolgáltatóktól.

\section{4. ábra: Vevői rezervációs árak eloszlásfüggvénye (példa adatok alapján)}

1200

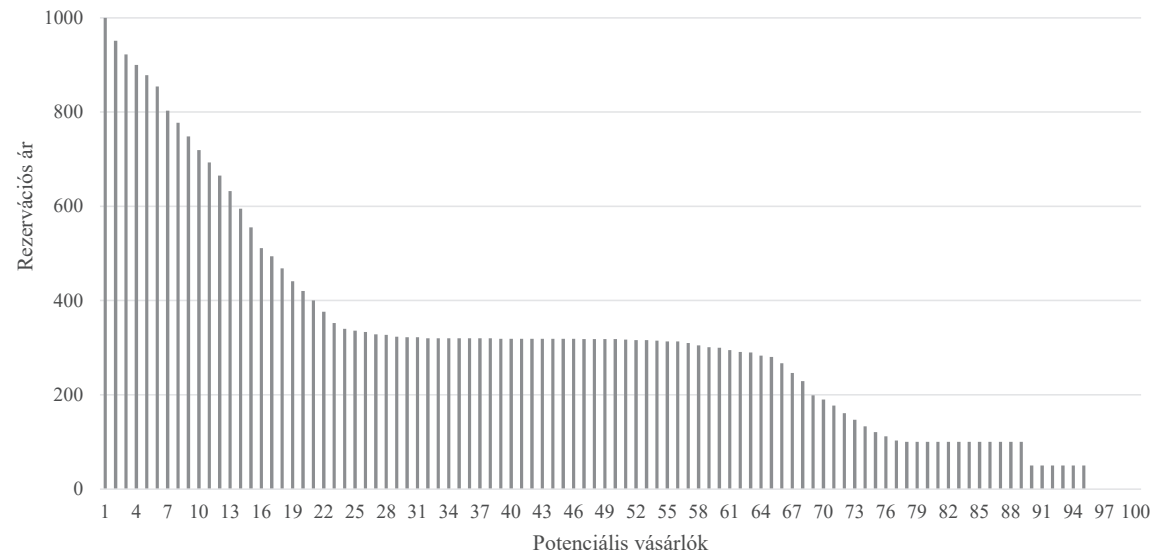

Forrás: saját szerkesztés 
A 4. ábrán példaként látható, hogy csökkenő sorrendbe rendezve a rezervációs árakat, jól elkülöníthetők az ügyfelek szegmensei, és felhasználhatók a vásárlási hajlandóság előrejelzésére.

A vásárlók rezervációs árának meghatározása nem csak az egyes vásárlók számára történő eladási ár szempontjából fontos, hanem azért is, mert inputként ez a legfontosabb adat az árrugalmasság meghatározásához. Ha ismerjük több száz, vagy több ezer vásárlónk rezervációs árát, akkor becsülni tudjuk az egyes termékek árrugalmasságát. Vagyis minden egyes árhoz meg tudjuk határozni a várható keresletet, hiszen csak azok fognak vásárolni, akik rezervációs ára nagyobb vagy egyenlö, mint az ajánlott fogyasztói ár.

\section{Az optimális ár meghatározása}

Az árrugalmasság alapján optimális árat lehet számítani az egyes termékekre. A korábbi definíció szerint ehhez a profitot kell meghatározni az ár függvényében. Első lépésként az árrugalmassági függvény alapján meg tudjuk becsülni a keresletet az egyes árértékekhez. A profit meghatározása ezután egyszerüen történik az ár, a kereslet és a fix költségek alapján, a jól ismert összefüggés szerint (pl. Smith 2012, 5)

$$
\pi=\mathrm{Q} *(\mathrm{P}-\mathrm{V})-\mathrm{F},
$$

ahol $\pi$ a várható profit, $\mathrm{Q}$ a becsült kereslet, $\mathrm{P}$ a javasolt ár, $\mathrm{V}$ a változó költség, és $\mathrm{F}$ a fix költség. $\mathrm{Az}$ 5. ábrán szereplő példában az egyszerüség kedvéért csak fix költséggel számoltuk.

Az így felrajzolt profitfüggvény alapján meghatározható az optimális ár, ha a költségadatok pontosan ismertek. Kifejezetten az optimális ár meghatározásához nincs szükség MI-re, ha az árrugalmasságot és a költségeket ismerjük.

\section{5. ábra: Az optimális ár meghatározása a kereslet- és profitszámításból (példa adatok alapján)}

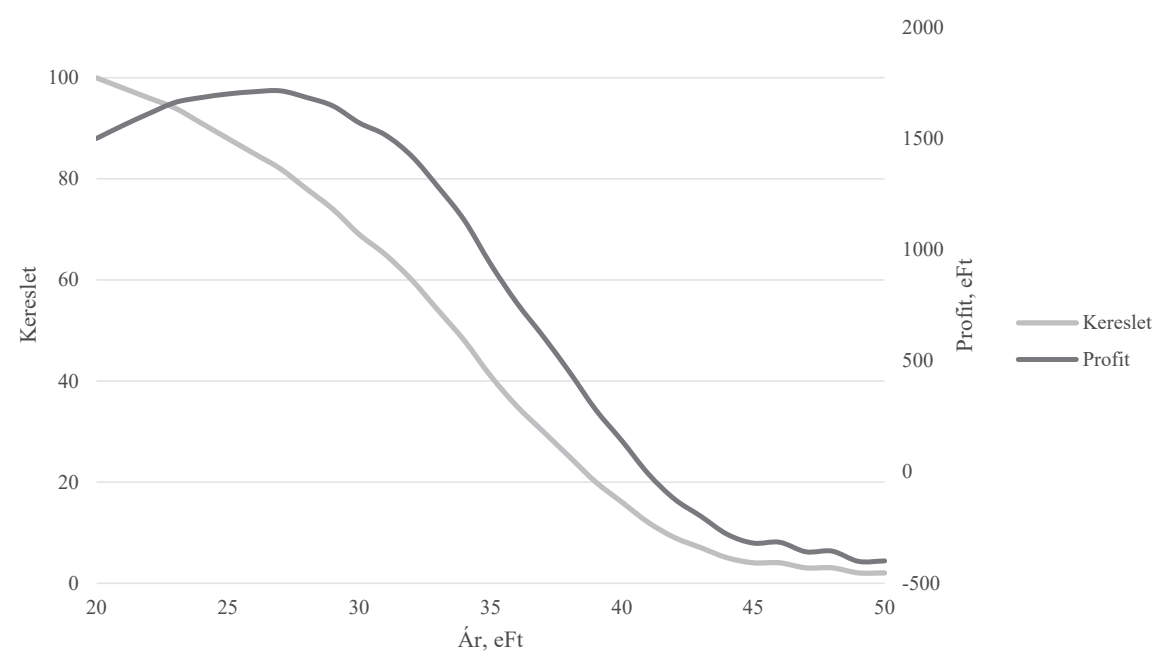

Forrás: saját szekresztés 


\section{Az optimális ár két és három dimenzióban}

A kereskedelmi árazás alapvetően azért bonyolult, mert az ár egy három dimenziós tér minden pontjára értelmezhető. Az egyik dimenzió a forgalmazott termékek köre, a másik dimenzió az idő, tehát a meghatározott ár érvényességi ideje, a harmadik pedig a vásárló, ill. a vásárlói szegmensek, hiszen nem biztos, hogy mindenkinek azonos áron kell adni egy terméket. A jelenleg elterjedt árazás egy (a termék), vagy legfeljebb két (termék és idő, vagy termék és vásárló) dimenziót vesz figyelembe. Az egyes termékekre eddig meghatározott „optimális ár” időtől és vásárlótól független, egydimenziós érték volt. Az optimális árat viszont meghatározhatjuk idődimenzióban, vagy vásárlói dimenzióban (vásárlói szegmensek szerint), vagy akár mindkettőt figyelembe véve három dimenzióban is. $\mathrm{P}$-vel jelölve az árat, $\mathrm{A}$-val a terméket, $t$-vel az időt, $C$-vel a vevőt, $\alpha, \beta, \gamma$.. betúkkel pedig az ármeghatározás további független változóit, mint például mennyiség, raktárkészlet, beszerzési ár, vevői árérzékenység, stb.), azt mondhatjuk, hogy a

$$
\mathrm{P}=\mathrm{f}(\mathrm{A}, \mathrm{t}, \mathrm{C}, \alpha, \beta, \gamma \ldots) \text { helyett a } \mathrm{P}(\mathrm{A}, \mathrm{t}, \mathrm{C})=
$$

$$
\mathrm{g}(\alpha, \beta, \gamma \ldots)
$$

függvény fogja leírni az árazás képletét. Röviden: skalármezö helyett vektormezö fogja leírni az árazást. Ennek gyakorlati szempontból annyi a jelentősége, hogy néhány év múlva értelmetlen lesz egy termék egydimenziós áráról beszélni idő és vevő dimenziók nélkül.

Az időben változó optimális ár azt jelenti, hogy rendszeres időközönként számítunk rezervációs árat, árrugalmasságot. Az idődimenzió skálája többféle lehet: folytonos, néhány óránként, néhány naponta. Ha csak egy-egy napra, hétvégére, rövidebb időszakra értelmezzük az optimális árat, akkor ezt a kereskedelemben árkedvezmény optimalizálásként tekinthetjük. Következmény tehát, hogy az MI eszközök alkalmazásával a jelenlegi árkedvezmények rendszere is teljesen átalakul: gyakran változó, akár pillanatnyi árak lesznek. Ha természetessé válik, hogy az aktuális kereslet hatására változik az árrugalmasság, akkor termékek ára is fog, akár naponta többször is. Ez már a dinamikus árazáshoz vezet.

A vásárlószegmensek szerint is lehet optimális árakat meghatározni. A szegmensek szerinti árdifferenciálás történelmi idők óta jelen van a gyakorlatban: legegyszerübb formában árkedvezményt jelent bizonyos vásárlói csoportok számára, például diákok és nyugdíjasok részére. Az elmúlt évtizedben lehetővé vált, hogy az online kereskedők folyamatosan figyeljék és elemezzék a vásárlói szokásokat, akár az egyes vevő szintjén is, és ennek alapján valós időben változtassanak árat (Bara 2017).

A marketingben megszokottól eltérő szegmentálás lehet az, hogy a rezervációs árgörbe (4. ábra) szerint osztályozzuk a vásárlókat. Így minden szegmensnek különböző árakat kínálhat a kereskedő, illetve ezzel egyenértéküen (csak más kommunikációval) eltérö mértékủ kedvezményeket vagy más járulékos értéket (szállítás, stb.) ajánl neki. A különböző vevőkörökre más ár lesz az optimális.

$\mathrm{Az} \quad \mathrm{MI}$ terjedésével várhatóan elterjed a néhány tucatnyi vevőre vagy akár néhány före vonatkoztatott mikroszegmentáció, aminek szélsőséges formája a teljesen személyre szabott árazás. A mikroszegmentációnak azért lesz létjogosultsága, mert az értékalapú árképzés szerint az egyes szegmenseknek más és más a termékről alkotott hasznosságképe, azaz a termék birtoklásának vagy szolgáltatás igénybevételének észlelt értéke, és az MI-vel kellően finoman lehet megkülönböztetni az eltérő értékajánlatokat.

\section{Személyre szabott árazás, aktuálisan optimális ár}

$\mathrm{Az}$ optimális árat minden egyes vevőre külön meghatározva személyre szabott optimális árról beszélhetünk, ami - ideális esetben - az ügyfél rezervációs ára. (Ha az optimális ár nagyobb a rezervációs árnál, akkor a vásárló nem fog vásárolni, ha pedig kisebb, akkor profitot veszít a kereskedő.)

A személyre szabott árazás mindeddig azért nem terjedt el a gyakorlatban, mert az ár meghatározása (személyes adatok elemzése, kedvezmény megállapítása, jogi korlátozások, pl. GDPR betartása) számottevő időbe és költségbe került volna. Amint ezek a költségek elhanyagolhatók lesznek, és gyakorlatilag valós időben rendelkezésre állnak, akkor használatuk is terjedni fog.

Elképzelhető, hogy egy olyan potenciális vásárló érdeklődik egy termékünk iránt, akinek a rezervációs ára alacsonyabb az aktuális optimális fogyasztói árnál: tetszik a vevő számára a termék, meg is venné, de drágának találja, mert például a konkurenciánál olcsóbban látta a terméket, vagy egy helyettesítő termék alacsonyabb áron elérhető. Ebben az esetben döntenünk kell, hogy a vásárlónak megadjuk-e azt a kedvezményt, amivel eléri a rezervációs árát, vagy pedig rábeszéléssel megpróbáljuk növelni a rezervációs árát. 
Ha a rezervációs ár mellett még marad elég profit, akkor valószínüleg érdemes megadni a kedvezményt, mert egyébként a potenciális vevőt (akár örökre) elveszítjük. Ennek a taktikának fontos előfeltétele, hogy a megállapított rezervációs ár pontos legyen, és az árkedvezmény tényleg vásárlásra ösztönözze a vásárlót.

A személyre szabott árazás ugyanakkor társadalmi és jogi kérdéseket is felvet, amelyekkel itt nem foglalkozunk, de több országban már elemzik a felhasználhatóság korlátait (Orlowski 2018, Zander-Hayat et al. 2016).

\section{VEVŐI OLDAL}

A MI eszközei nem csak a kereskedő számára lehetnek hasznosak, hanem a vásárló számára is, ezért többféle árazástámogató eszköz fog elterjedni a vevői oldalon is. A teljesség igénye nélkül bemutatunk néhány várható megoldást:

- A támogató rendszerek - megfelelő becslésekkel - meg fogják tudni határozni a vásárolt termék teljes bekerülési költségét (szállítással, kötelező tartozékokkal, stb.), ami fontosabb összemérési alap lesz, mint maga a fogyasztói ár.

- Elterjedhet a termékek életciklus (teljes élettartam) költségszámítása, amibe pl. a garancia is beletartozik. Így a vásárló nem csak a közvetlen fogyasztói árakat tudja majd összehasonlítani, hanem több évre vonatkozóan a várható teljes fenntartási költséget, pl. egy mosógép esetén az áram- és mosószerfogyasztás, valamint karbantartás és javítás költségeit.

- Meg fognak jelenni azok a tanácsadó rendszerek, amelyek megmondják, hogy mit, mikor, mennyiért érdemes vásárolni. Az ajánló rendszer szól a tulajdonosnak, hogy mikor ér el egy adott termékakció olyan ár-érték arányt, amikor már érdemes megfontolni a vásárlást. Várhatóan elterjednek azok az „okos” árfigyelö, akciófigyelö, árelemző termékek és szolgáltatások, amelyek MI algoritmusokon alapulnak és személyes preferenciákat (márka, minőség, árkategória) is figyelembe vesznek.

- A tanácsadó rendszerek hatására a vásárlói oldal is fellép árigénnyel. Noha elvileg erre most is lenne lehetőség, a kereskedőknek egyelőre túl drága egyéni igényekkel foglalkozni, de egyes aukciós portálokon már kísérleti jelleggel próbálkoznak ezzel a lehetőséggel. A vásárlói oldal megszólításával megvalósulhat az árigények mérése, ami pedig finomabbá teheti a rezervációs ár meghatározását.

\section{ÖSSZEFOGLALÁS}

A következő évtizedben a kereskedőknek egy új eszközcsalád fog majd rendelkezésre állni (kezdetben megkülönböztető jelleggel), hogy profitot növeljenek. Nem csak a gépi tanulás, hanem MI algoritmusokkal támogatott adatelemzések és kommunikációs megoldások is támogatni fogják az eladókat, majd - időben kissé később a vevőket is. Bemutattam, hogy a dinamikus és értékalapú árazások egyre jobban elterjednek a lakossági kereskedelemben. Az MI korban az olyan árazáshoz kapcsolódó közgazdasági elméleti fogalmak, mint rezervációs ár vagy árrugalmasság egyre pontosabban számíthatókká válnak, lehetővé téve az optimális ár meghatározását a kereskedők számára. A dolgozatban bemutattam az optimális ár kiszámításának egy olyan lehetséges folyamatát, ami arra épít, hogy MI eszközök felhasználásával jó közelítéssel becsülni lehet majd a termékek árrugalmasságát és a vevők rezervációs árát. Megállapítottam, hogy a jövőben az egydimenziós „ár” elavul, és jellemzőn három dimenziójú árakról fogunk beszélni, idő- és vevődimenziókat is figyelembe véve. Az MI számításokhoz és az adatvezérelt árazáshoz sok adatra lesz szükség, amihez kapcsolódóan csoportosítottam a felhasználható adatforrásokat. 


\section{HIVATKOZÁSOK}

Bara Z. (2017), „Dinamikus árazás az online kereskedelemben - Hogyan lehet hátrányos a fogyasztónak a dinamikus árazás?", Versenytükör 2017/2, pp. 5-18.

den Boer, A. V. (2015), „Dynamic pricing and learning: Historical origins, current research, and new directions" Surveys in Operations Research and Management Science, 20 1, 1-18

Danyi, P. (2019) „A mesterséges intelligencia az árazásban" Marketing és Menedzsment, 52 3-4, 5-18

Macdivitt, H., Wilkinson, M. (2012) Value-based Pricing, McGraw-Hill

Orlowski, A. (2018), „UK.gov asks: Are sadistic AI price-bots ganging up on you?", 2018.10.12. https://www.theregister.co.uk/2018/10/12/ uk_government_digital_competition_inquiry/, letöltve: 2018.11.05.
Rekettye G. (2012), „Az árak észlelése és értékelése", Vezetéstudomány, XLIII 5, 2-13

Rekettye G. (2018) „Gondolatok a digitalizáció fejlődéséről és az árakra gyakorolt hatásáról"' In: Dobrai K., László Gy., Sipos N. (szerk.) Ferenc Farkas Int'l Scientific Conference, Pécs, Magyarország , 2018.06.07 -2018.06.08. Pécsi Tudományegyetem Közgazdaságtudományi Kar Vezetés- és Szervezéstudományi Intézet, pp. 245-261.

Rekettye G. - Liu, J. (2018), Pricing: The New Frontier, Transnational Press London

Smith, T. J. (2012), Pricing Strategy: Setting Price Levels, Managing Price Discounts, \& Establishing Prie Structures, South-Western, Cengage Learning

Zander-Hayat, H., Domurath, I., Gross, C. (2016), Personalisierte Preise, Sachverständigenrat für Verbraucherfragen beim Bundesministerium der Justiz und für Verbraucherschutz, August

Danyi Pál PhD, egyetemi docens danyi@mvt.bme.hu

Budapesti Müszaki és Gazdaságtudományi Egyetem Menedzsment és Vállalkozásgazdaságtan Tanszék

\section{Expected impact of Artificial Intelligence on Pricing}

\section{THE AIMS OF THE PAPER}

Technology and tools of Artificial Intelligence (AI) will disseminate in more and more business areas in the near future, including marketing and pricing. Our aim is to present how data driven techniques will impact on pricing and change the pricing practices of enterprises.

\section{METHODOLOGY}

In this conceptual study I analyzed the expected impact of AI methods, based on the detailed research I carried out earlier. My study inspects the most important process steps of pricing.

\section{MOST IMPORTANT RESULTS}

I prove in my research that data driven technologies supported by AI tools will bring fundamental changes in pricing in the next decade. I developed a potential AI-based process of establishing optimal prices. I offer a proposal to expand the one dimensional price of a product into three dimensions including time and customer.

\section{RECOMMENDATIONS}

Value-based and dynamic pricing will spread widely due to AI. Reservation price, price elasticity, and optimal price are those theoretical concepts that will gain practical relevance with the usage of AI: all companies will be able to calculate those values by which profit can be increased significantly.

Keywords: artificial intelligence, intelligent pricing, dynamic pricing, machine learning, data driven, optimal price, personalized price 



\title{
A Fault in Our Stars: Competitiveness among Michelin-star Restaurants
}

\author{
Ilona Miklós
}

Corvinus University of Budapest

\section{THE AIMS OF THE PAPER}

Hospitality is a creative industry. A national cuisine may contribute to a country's competitiveness by considering the various elements of sustainability in a region, stimulating economical development, and improving the national image. In Europe, the Michelin Star system is the most respected ranking system for high-quality or haute cuisine restaurants. This research is based on whether the characters of Hungarian cuisine can be identified by domestic fine-dining representatives.

\section{METHODOLOGY}

Using qualitative research and content analysis methodology, the paper explores whether fine-dining professionals and Michelin Star restaurants can identify local gastro culinary in the public dialogue.

\section{MOST IMPORTANT RESULTS}

Prizing a Michelin Star could be an innovative or sustainable business strategy, meeting as it does the gastronomic expectations of tourists. Providing a theoretical framework of the relevant literature on the role of innovation within the gastronomy industry, this paper analyses interviews collected from an online media platform. Although not all are covered in this paper, location, co-working, wellbeing and existential balance, inspiration, and burnout are factors identified during the research, factors that could drive Hungarian cuisine in a different direction than others in the international field.

Keywords: gastronomy, sustainability, content analysis 


\section{INTRODUCTION}

Gordon Ramsay, awarding Michelin Stars for the UK \& Ireland 2019, described the event as the „Oscars of the restaurant industry" (HeightonGinns 2018). Basque and Catalan cuisines are more acknowledged than the Spanish (Andrews 1997). Tuscan hospitality and culinary delights are special treats for those visiting Italy (Kivela \& Crotts 2006). Foreign chefs with Michelin Stars are independent brands, competitive partners, and TV stars. At home, many Hungarians claim that although theirs is a small nation, the cuisine is world famous (Molnár 2012).

Fine-dining restaurants are full-service restaurants with refined and delicately assembled cuisines, specializing in dinner-based meals costing $~ € 50$ 70. They are characteristically high-end, luxury, upscale restaurants with elaborate and intentional decor and furnishing. Fine-dining is stable and less responsive to negative trends. In general, they are lower volume than quick-service restaurants, while still generating comparable revenue.

This study aims to find major characteristics of socio-spatial levels of the Hungarian fine-dining sector to discern creative industry patterns. Various forms of culinary globalization processes have been defined by chefs and locations in the fine-dining sector worldwide. But is the Hungarian fine-dining sector stable and responsive to global trends?

The development process of Michelinstarred chefs has similarities and differences to traditional concepts of new product development (Harrington et al. 2014). This combination of global factors is new to hospitality as a creative industry and their existence/absence influence the success of the Michelin Star restaurants and their ability to compete in the local market.

The successful adaptation of economically useful knowledge is an important opportunity in making the hospitality industry more competitive (Ottenbacher \& Gnoth 2005, Töröcsik 2010), while competitiveness guarantees constant reformation and innovation (Harrington 2004). But not everyone can adapt this economically crucial knowledge within the industry.

This study aims to find major variables that define the characteristics of Michelin Star restaurants, assessed by professionals. It focuses on the roles that professional engagement in gastronomy and company location play in relevant knowledge transfer in Hungary, and the influences on the heterogeneity of consumption in fine-dining restaurants.
Taking interdisciplinarity into consideration, Section 1 introduces the creative fine-dining hospitality industry. Section 2 presents regional characteristics of deterritorial structural shaping factors. Section 3 offers an overview of theoretical frames of innovation and creativity. Section 4 introduces a methodological description and qualitative content analysis. Section 5 discusses interviews with 25 selected chefs, owners, and investors in Hungarian top gastronomy. Section 6 concludes with the interpretation of results, the research limitations, and potential future research options.

\section{THEORETICAL FRAMEWORK}

Many disciplines are interested in the academic approach to food and eating out. Interdisciplinary research encompasses anthropology (Elias \& Hammer 1939, Lévi-Strauss 1968, Douglas \& Khare, R. 1979, Appadurai 1981) which sees eating habits as expressive tools of cultural relationships, sociology (Mennell 1996, Bourdieu 1979) and marketing (Törőcsik 2010, 2011, 2016) which examine different socially constructed narratives.

\section{Creative industry}

The fine-dining hospitality industry sees itself as part of the creative economy. The creative economy is basically the triad of creative industries, cultural industries, and knowledge-intensive industries. The creative industry has two main strategies (Zarlenga et al. 2016):

1. The concentration emerging from the so-called cultural or creative industries (film, radio, television), web design, textiles, graphics, fashion, advertising, photography, and architecture (Scott 2000).

2. The developed strategy, which aims to establish cultural services in settlements to attract tourism and related enterprises by regaining the existing heritage (urban regeneration), by setting up cultural institutions (e.g. museums), or organizing big events. 


\section{Figure 1: The frame of Michelin stars}

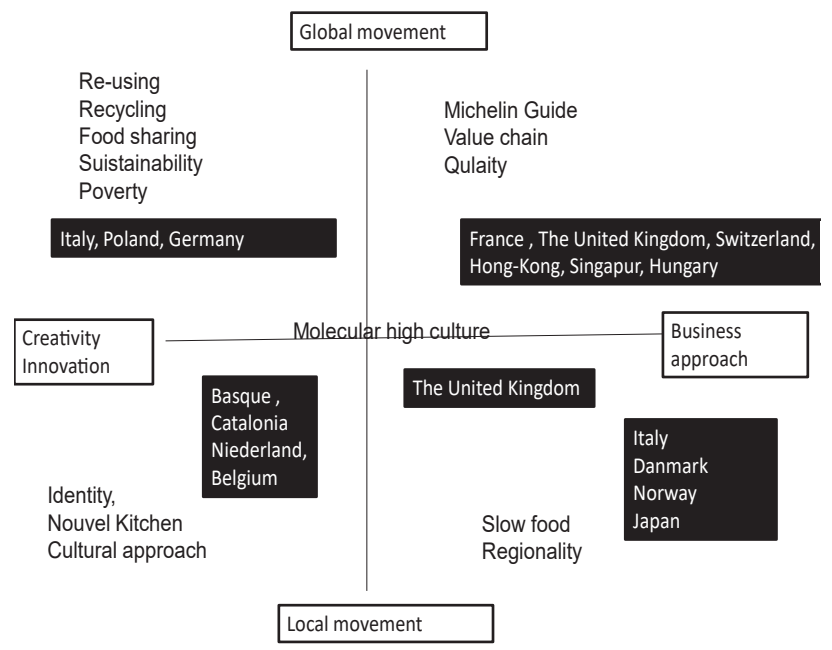

Source: own edition

They both treat innovation and knowledge creation processes in their contexts, i.e., they do not separate them from their true, spatial economic and social processes (Figure 1).

According to Prahalad and Ramaswamy $(2004,5)$, "The meaning of value and the process of value creation are rapidly shifting from a productand firm-centric view to personalized consumer experiences." The market advantage of hospitality depends on whether it stays in or falls out of the net of value creation processes. Competitiveness and innovation are inseparable, but the trend we see relates to the appreciation of international reputation and its accompanying positive impacts. These go beyond the new or significantly improved product, service, or process.

\section{Fine dining}

The French term "haute cuisine" literally means "high cuisine" or "excellent cuisine." It is characterized by unique and particular preparation, processes, and serving modes. In the 1970s, in line with the French dominance of gastronomy, haute cuisine meant "la nouvelle": new cuisine that went against mainstream traditions, including new cooking methods, recipes, and ingredients, still influenced by great French gastronomical traditions (Giuri \& Mariani 2006). Today, haute cuisine covers higher levels of gastronomy, separating these from traditional segments of hospitality (Bojanic \& Rosen 1994).
The English-speaking world embraced the English version of the term - fine dining - which is applied to Michelin Star restaurants to distinguish them from casual-traditional dining. Since the first Michelin Guide or Guide Rouge published in 1900, it has been the world's leading evaluation system (Surlemont \& Johnson 2005). Anonymous reviewers visit all segments and price categories of the hotel and hospitality industry. The number of stars ranges from 1 to 5 and plays a significant marketing role. Losing a star could result in as much as a $50 \%$ setback (Surlemont \& Johnson 2005) in terms of sales.

While fine dining is a vibrant, expansive niche sector of the global restaurant market, consumer values are shifting towards convenient eating and restaurants are evolving their menus to accommodate. Compared to $2016,37 \%$ of diners are now looking for value-priced meals (Technomic 2018), Millennials (46\%) in particular are hungry for deals. As diners increasingly associate eating out with an opportunity to post on social media, restaurants race to remodel stores to boost the "experience" factor. Front-of-house design has Instagram in mind, and consumers expect more from the restaurant than just a good meal. 


\section{Globalization of culture}

Globalization plays a significant role in creating and transforming different economic, social, and environmental processes. Economic and social structural changes in turn lead to spatial and environmental changes (Rechnitzer - Lengyel 2000). Investor behaviour is constantly evolving and changing along the centre-periphery of power relations, contributing to the transformation of traditional consumption and lifestyle.

The globalization of culture as a movement of symbols, styles, and practices over an extended space, has been portrayed as highly pervasive (Appadurai 1990). It takes several contrasting forms. Cook and Crang $(1996,137)$ use the globalization of culture to distinguish the local. In contrast, the pluralization of cultural styles and competition between them is more likely to marginalize the local. Pieterse $(1995,49)$ defines the hybridization of cultural forms as separated from existing practices. Tomlinson (1999) refers to the process of local cultural resistance as re-territorialization.

\section{International directions of stars}

\section{Molecular high culture}

The traditional Spanish food renewal movement started in the 1970s in the Basque territory, where chefs interpreted/translated French nouvelle cuisine ideas into Basque, and named it Nueva cocina vasca (New Basque kitchen) (Andrews 1997). Ferran Adrià, a Catalan chef was named as one of the ten most remarkable innovators in 2004 by Time magazine (Graff 2004). In the scientific cooking style he introduced in El Bulli, he merged molecular science with culinary practice (Svejenova et al. 2007). Thus molecular gastronomy became a new and accepted cooking style. Adrià's success affected the cooking style of leading Spanish chefs who now often associate themselves with molecular gastronomy. His success revolutionized Spanish cuisine. Using scientific knowledge has become a pillar of Spanish creativity, where the focal point is the innovation of new raw materials, techniques, and ideas. "Cooking is a language through which all the following properties may be expressed: harmony, creativity, happiness, beauty, poetry, complexity, magic, humour, provocation, and culture" (Adrià et al. 2005). Adrià was invited to Kassel, to the forum of contemporary arts, where modern cuisine was introduced as a factor of the genre. Magazines now write about El Bulli in their culture columns, starting a dialogue between gastronomy and other forms of art.

\section{Slow food and food share}

Massimo Bottura's Osteria Francescana longknown for its philosophy of "cooking is sharing" tops the "World's 50 Best Restaurants List." Donating and sharing food is a cultural project, i.e., an organic part of the creation and the process (Tonon 2016). Counteracting the "fast food" phenomenon, northern regions of Italy are leading the increasingly popular slow-food movement. It focuses on the slow, attentive, traditional, and noble intake of food. Bottura not only speaks (Law 2016) about it but also publicizes the organizational culture of his kitchen conception. The soup-kitchen chain, Refettorios, had an active role in the Rio Olympics, sending leftovers from the Olympic village to the needy. Food for Soul, now a movement, has the support of Michelin Star chefs Alain Ducasse and the Spaniard Joan Roca. Bottura's initiatives aim to have less food end up in the trash (Law 2016) and have the surplus - by minimizing losses and in a re-thought form - reused on the plate, no matter what kind of restaurant(Michelin Star or soup kitchen) the food originated from. He speaks to the public via social media about the concept of reuse and reallocation, attracting supporters (e.g. Robert de Niro), and starting discussions on topics such as the right to good food, the reuse of leftovers, and poverty. "We are not thinking in terms of pop-ups. We plant seed, and our goal is to start growth and cover all of Earth" (Adams 2017).

\section{Tales from the North}

The Scandinavian kitchen concept - New Nordic - was made famous by a Danish kitchen. Restaurant Noma owes its Michelin Stars to René Redzepi and his team, who established creative workshops called food labs or kitchen labs. Experienced chefs from all over the world stand in line to observe and learn in Noma's kitchen. Traditional Scandinavian raw materials and cooking methods are merged with innovative gastronomical thinking, an advantageous combination for Northern chefs competing at the Bocuse d'Or. The unusual ingredients of New Nordic are plated as perfect commodities; even the chefs help gather them. According to Redzepi, everything has a story. While he works on the raw materials in the background, he creates a story out of them, and tells this story at the table. Redzepi believes (Jenkins 2017) that stories need to be 
shared. Only by talking can we find our own stories in food and in life.

\section{Hungarian tradition}

Costes in Budapest received Hungary's first Michelin Star (Index 2010). Three other restaurants have joined this prestigious group of fine-dining restaurants. Civil gastronomical traditions in Hungary stopped after WWII, replaced by the party-state's public catering strategy, resulting in the stereotypical hospitality we experience so widely today. "Volume above all" was the slogan that shaped gastronomical education and industry dialogue. Only large-scale hospitality survived this era for over half a century (Keszeg 2011, Báti 2000, 2008, 2009). Cooperation between professionals within agriculture, the health industry, and environmental protection disappeared from professional kitchens in recent decades. To solve the situation, the Hungarian Gastronomical Association (MGE) launched its gastronomical lobby under the name Culinary Charter 2007 (Kulináris Charta 2007). Its mission is to repair the Hungarian eating culture by shunting negative processes. Thanks to this movement that originates from outside of the profession, in 2019, Costes, Borkonyha Winekitchen, and Costes Downtown, Stand and Babel have one Michelin star, and Onyx has two. Compare this to Austria's 13 one-star and 7 two-star restaurants. Or 2 one-star restaurants in both the Czech Republic and Poland. While Hungary, the Czech Republic, and Poland only boast Michelin-star restaurants in their capitals, Austria's include Salzburg, Hallwang, and Kleinwalsertal.

For the Basque region, the introduction of an independent fine- dining gastronomy contributed to defining its national identity. An Italian Michelin chef is looking for solutions to global issues by introducing poor-kitchens and reusability concepts to the public. The Danes built a two-star Michelin restaurant brand with the help of local stories and limited raw materials. Hungarian cuisine, however, is looking for a breakthrough by separating itself from the mundane, and by redefining traditions with initiatives coming from above (Molnár B. 2012).

\section{Knowledge, creativity, and innovation}

Schumpeter's theory of "creative destruction" (1939) appears as a new combination of production factors which achieves professional development while constantly fighting the environment. According to Schumpeter, the main point of capitalism is the search for innovation opportunities, during which innovation is an aggressive drive to destroy the balance. The environment embodies continuous fight and movement, i.e., "creative destruction", and also creates a dynamic, sensitive selection process.

Schumpeter's five base cases of innovation:

1. Goods yet unknown to new consumers

2. New production processes which are yet unknown in the given industry

3. New placement opportunities, i.e., the opening of new markets

4. New supply sources of raw materials or semi-finished goods

5. Establishment of a new organization or the abolition of an organization.

According to the Oslo Manual innovation activities are "all scientific, technological, organizational, financial and commercial steps which actually, or are intended to, lead to the implementation of innovations (Galindo-Rueda \& Van Cruysen 2016).

Amabile's definition of creativity is "the production of new and useful ideas in any fields" (Amabile et al. 1996, 2). Here, "useful" suggests that an idea can create a short- or long-term increase in value, whereas "novelty" covers all ideas that represent uniqueness compared to those available at the time. Innovation "realizes the successful manifestation of creative ideas within an organization" (Amabile et al. 1996, 2), i.e., innovation cannot manifest itself without some form of creativity.

This paper uses the expression "culinary creativity," which may mean several things in the context of restaurants. It could be related to cooking methods, new flavours and flavour-combinations, smells, visual aesthetics and composition, presentation, or serving. Innovation means fulfilling consumer demand at a new, higher level by consumer orientation, novelty, and uncertainty (Chikán 2017). Krugman (2000) drew attention to the positive externality of access to knowledge noting the knowledge-spillover effect that automatically takes place between companies.

\section{Implementation}

The theoretical literature on the analysis of implementation traditionally distinguishes top-down and bottom-up changes, i.e., programmed and adaptive-evolutionary changes (Darling-Hammond 1998, Fitz et al. 1994). Research related to top-down types of change focuses on the realization of decisions made in the centre. This approach assumes the process to be hierarchical and linear. 
The bottom-up approach emphasizes the importance of the changes starting from below, i.e., local-level implementers, street-level bureaucrats, and local institutions (Fitz et al. 1994).

Research focusing on micro processes, breaking the dominant conception of a top-down perspective that focuses on implementation loyalty, had a significant role in the experiences of the two approaches drawing closer together. As for adaptation opportunities, four so-called implementation trails exist: unsuccessful adaptation, technological adaptation, formal implementation, mutual adaptation.

\section{METHODOLOGY}

The context of this study is fine-dining restaurants in Hungary. Single-industry studies are criticized for being too narrow in scope and presenting problems in generalizing the results and using the findings for theory building. This research methodology uses both manual and electronic qualitative data analysis approaches labelling ,interpretive" research where the researcher is attempting to interpret their meaning. The aim is to focus attention on the researcher and their contribution to the data creation and analysis process.

\section{Qualitative content analysis}

Qualitative content analysis (Mayring 2000) uses several techniques in the systematic analysis of texts, when it looks for the content of the communication in the document. Content analysis is a retrospective research method, based on the exploration of the structure of inner characteristics and context, comparing insights of interviews, and looking for common points and different characteristics during narrative analysis to classify them into groups. Data used in this paper are qualitative. In the qualitative element, 25 plus 3 extra interviews were held with chefs and fine-dinning restaurateurs with different decision-making powers.

\section{Location and date of sampling}

Interviewees were chosen from the list of restaurants, chefs, and hospitality experts awarded in Dining Guide's February 2018 publication for their achievement in 2017.

1. Dining Guide's website is the most frequented, professionally significant portal with its own Facebook profile and its own evaluation system.
2. Albeit in a Hungarian context, its point system and categories are a close match for Michelin's international reputation.

The Chef de Cuisine (Executive Chef) has the most power in the kitchen; they are responsible for food quality, revenue, cost, culture fostering, guest feedback, menu conceptualisation, procurement, and training.

Next is the Sous Chef who is responsible for planning and directing food preparation; ensuring the highest standards and consistent quality in the daily preparation; and keeping current with new products, recipes, and preparation techniques.

The Trainer Chef or Coach is part of the team, too. An R\&D culture with mentoring in the kitchen could reduce staff turnover and motivate the kitchen staff. The Coach is a culinary leadership expert, who outlines the best practices for staff coaching and hospitality skills.

The Lobbyist is an activist seeking to persuade members of the government to enact legislation that would benefit their group. They seek to assert their own alignment of quality conventions through the lobbying efforts of their national organization (Pannon Akadémia) and their affiliation to the Bocuse d'Or.

Restaurant Owners are responsible for the daily operations as well as the overall direction, profitability, and reputation. Some are extremely hands-on, helping out in the kitchen and interacting with customers, while others hire managers and focus on strategic planning. They spend much of their time supervising employees, directing operations, and finding ways to adapt to customers and industry trends.

Executive Chefs who are Restaurant Owners have many years of experience in the restaurant industry. To improve their skills, they have the option of taking workshops and classes or obtaining certifications.

This study is based on the content analysis of 25 interviews: seven Executive Chefs, two Sous Chefs, a Trainer Chef and Coach, a Lobbyist, eight Owners/Investors, and six Executive Chef/Owners. Out of 25 interviews three have business in countryside, others are Budapest based. These 2017 interviews were downloaded from http://www. diningguide.hu between March and May 2018. Data analysis was completed with three interviews with international chefs - Ferran Adrià, Massimo Bottura, René Redzepi - to reflect and value Hungarian data. 


\section{Encoding phase}

Defining the research problem and closely planning the research kills creativity, according to Glaser and Clark (1992), forcing already existing theories onto the result. It does not give space to the solution where the researcher applies a more general approach and lets the research problem be concretized during the research process (Mitev 2012).

NVivo 9.0 was chosen over other packages because it was free. It was used for encoding to define the most frequent expressions and tools of speech in the 25 interviews. First the text was coded into a format NVivo 9.0 could handle. Then a word frequency function was used to choose the texts to be examined. Finally, a filter based on position and operational site was applied to segment samples to sub-groups:

\section{By position}

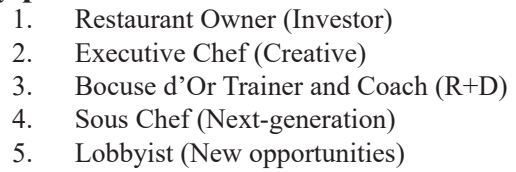

\section{By location}
1. Budapest
2. Countryside
3. International

While processing the content encoded in the first working phase, the system examined whether in the case of a code category, the given occurrence frequencies were repeated. It also examined the most frequently used words and expressions based on occurrence, which was later confirmed by the help of a wordcloud app to make the not yet present expressions (latent content) visible. Because every code symbolizes a meaning, the common occurrence of two or three codes created a "report surplus," which was not present in the original text. Yet here, even the lack of something can become an important content indicator.

\section{Interpretation phase}

Common occurrences in the text suggest laws which can be interpreted. However, it also happens that the document lacked a code (and thus a concept represented by the code) which we would expect in the given content - e.g. because it appeared in similar documents before. In this case, it was found a not present, latent momentum, which could be significant because of its "meaningful disappearance."

\section{RESULTS}

\section{Where should Hungarian gastronomy head now?}

\section{By operational site}

The analysis of the interviews confirmed that Budapest is the focal point of Hungarian gastronomy. It plays a significant role in gastronomy as a geographical location. Budapest hospitality players do not hide their desire to appear on international levels, targeting Austria, Italy, and the USA. In contrast, international chefs generally define their home country as a reference, and the region, city or town where their enterprise is based (e.g. Dortmund, Bologna).

Unlike those in Budapest, investors in the countryside are aware of the reality outside of Budapest. Restaurant owners and chefs also mention Miskolc, Nyíregyháza, Kassa, Balatonszemes, Pannonhalma, and Györ among the settlements close to their HQ. One of the chefs has a tattoo with the GPS coordinates of Györ, so as not to forget where he started off. For Hungarian restaurant owners and chefs, Spanish and Italian examples are the main attractions in terms of international expertise.

\section{By position}

Restaurant owners and investors focus on industry, profession, and sector instead of geographical regions, while chefs look for parallels with US one-star Michelin counterparts

The Lobbyist would like to gain more insight into the operation of two-star restaurants, to see what takes a restaurant to the top. Surprisingly the lack of next-generation chefs and raw materials does not concern them; they focus on potential political connections and strategic partnerships both domestic and foreign.

Chefs and owners who have already travelled the road towards a Michelin Star and taken part in the Bocuse d'Or internationally, highlight regionality and the importance of workshops when talking about international experiences. 


\section{What goals should hospitality set?}

Permanent and readily available ingredients as well as a skilled, dedicated workforce are the main obstacles to development.

\section{By working site}

Budapest chefs create fabulous food of the highest quality, while those in the countryside focus on average, family-friendly delicacies in restaurants where guests and staff know each other. Here, making a mistake would adversely affect the business in the long run. Foreign chefs look at food as a creation, with a philosophy. For the needy, the food is an experience, just like a painting. Hungarian hospitality experts agree on the need to cooperate more closely with wineries and wine regions.

\section{By position}

Investors would like to see a concept that serves long-term expectations in fantastic restaurants, where risk-taking is tolerable and the restaurant provides an attainable service for those affected.

Chefs mainly imagine rational gastronomy in Hungary, where food is created from top-quality ingredients for international guests, with clearly identified methods and a financially stable business model. The best combination is outstanding food with good service.

The Lobbyist's main goal is to reach the twostar Michelin level, their determinant of success.

When it comes to the next generation, the primary task seems to be effectively addressing young aspirants. They get their opportunities from the owners, therefore the experts trust that the next generation of chefs will be just as important for the entrepreneurs in the future as international recognition is right now.

\section{How will fine dining achieve the goals set?}

Besides the geographical or location aspects of content analysis, we need to examine the verbs, i.e., how the participants imagine the realization of their plans.

\section{By operational site}

Those in the countryside see practical ways to reach their goals. They share experiences among themselves that enable them to pursue new ways. For those in Budapest, dialogue is important in building networks, but without unique contacts, development is inconceivable.

International chefs think of responsible practice. They also taste everything and if possible, take part in charitable initiatives. Encourage, motive, and taste are verbs which suggest stability and safety besides getting acquainted with the novelties of innovation.

Investors see themselves as objective bystanders. When it comes to verbs, they mainly use conditionals: would like to, would repair, would try. They do not take risks or side-effects casually.

The Lobbyist, for whom strategic networking is important, mainly focuses on tasks and action. When it comes to methods, he is more likely to deal with those he agrees with.

Chefs are dedicated and do their best to move on after failures. They have a practical approach to realizing their visions, and prefer automatic, regular tasks.

For the next generation, a mentality based on recognition is ideal. They believe in workshops and values brought from home. Other important aspects are the role of the father and their intention to make him proud.

\section{CONCLUSION}

Fine dining is a creative industry consisting of a diverse group of people working together under one roof and in one kitchen. Managing the front-ofhouse (customers) and the back of the house (employees) is not easy. But can Hungarian cuisine characteristics can be identified by finedining representatives? Could the global culinary cultural innovation performance of Hungarian fine-dining hospitality be recognized in domestic public dialogue?

Interview analysis confirms that in Hungary, Budapest is the gastronomic focal point. There is little competition between locations; the rural area is more likely to be marginalized. New processes and technological skills are helping, but the innovative organizational theories lack financial and raw ingredient resources. While foreign chefs look at food as a creation, which has coherent characters or well-built stories with a philosophy, the content analysis of the top 25 Hungarian interviewees 
shows that there is much discussion about possibilities such as new business concepts or reform, but this does not lead to action. Among hospitality entrepreneurships, even if they set a Michelin
Star(s) as a goal, their needs and expectations are different, which does not guarantee success at system level in the long run.

\section{Figure 2. Period of competetiveness and innovation}

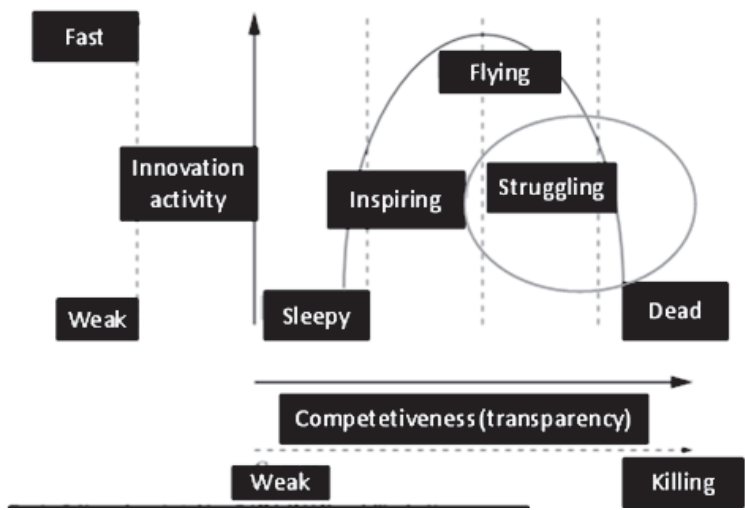

Source: Aghion and Griffith (2005)

Different stakeholders have different perceptions of Hungarian cuisine with no common thought as to how to promote it internationally. It seems no unified conception or possibility for discussion exists which could result in defining a breaking point to catch up with the Michelin Star owners' club in the long run.

\section{Validity and reliability}

Kirk and Miller (1986:21) suggest that validity in qualitative research "is ... a question of whether the researcher sees what he or she thinks he or she sees" so that there is evidence in the data for the way in which data is interpreted. Qualitative data analysis is "impression analysis" because of the lack of detail and scrutiny of how the analysis process itself is carried out.

\section{Limitations of this study}

The scope of analysis is limited to the high-end fine-dining category and the Michelin Star segment of the hospitality industry. It aims to understand the embeddedness of innovation in terms of culinary creativity, and how the results apply to the Hungarian gastronomical environment. Yet during the research process, secondary foreign sources were used, some related to other regions because like other industries, hospitality is becoming more and more global. 


\section{HIVATKOZÁSOK}

Adams, T. (21/05/2017), ,Massimo Bottura and his global movement to feed the hungry", https:// www.theguardian.com/lifeandstyle/2017/ may/21/massimo-bottura-feed-the-hungryfood-for-soul The Guardian Online [accessed 10/15/2018]

Adrià, F, Sorel, J., Adrià A. (2005), F. El Bulli 1998-2002, Ecco, London

Amabile, T. M., Conti, R., Coon, H., Lazenby, J., Herron, M. (1996), ,Assessing the Work Environment for Creativity", Academy of Management Journal 39 5, 1154-84 DOI: https://doi. org/10.2307/256995

Andrews, C. (1997), Catalan Cuisine: Europe's Last Great Culinary Secret, Grub Street Cookery

Appadurai, A. (1981), "Gastro-politics in Hindu South Asia", American Ethnologist, 8 3, 494-511 DOI: https://doi.org/10.1525/ ae.1981.8.3.02a00050

Appadurai, A. (1990), „Disjuncture and difference in the global cultural economy," Theory, culture \& society, 7 2-3, 295-310. DOI https://doi. org $/ 10.1177 / 026327690007002017$

Báti A. (2000), „A lakodalmi étrend, ételek változása 1941-1996." in: Herman Ottó Múzeum Évkönyve XXXIX. 481-96

Báti A. (2008), Régi és új elemek a cserépfalui konyhán, Budapest: Magyar Néprajzi Társaság

Báti A. (2009), „A jól felszerelt konyha. Kell ma még tudni fözni?" Ethnographia, 120, 255-66

Bojanic, D. \& Rosen, D. (1994), "Measuring service quality in restaurants: An application of the SERVQUAL instrument", Hospitality Research Journal, 18 3-14 DOI: https://doi. org/10.1177/109634809401800102

Bourdieu, P. (1979), "Symbolic power", Critique of Anthropology, 4 13-14, 77-85 DOI: https://doi. org/10.1177/0308275x7900401307

Chikán A. (2017): Vállalatgazdaságtan, 5. kiadás. VTOA, Budapest.

Cook, I., \& Crang, P. (1996), „The world on a plate: culinary culture, displacement and geographical knowledges", Journal of material culture, 1 2, 131-53 DOI: https://doi. org/10.1177/135918359600100201

Darling-Hammond, L. (1998), "Policy and change: Getting beyond bureaucracy", In: Hargreaves A., Lieberman A., Fullan M., Hopkins D. (eds) International Handbook of Educational Change. Springer, Dordrecht DOI:https://doi. org/10.1007/978-94-011-4944-0 32

Douglas, M. and Khare, R. S. (1979), "Commission on the anthropology of food: statement on its history and current objectives", Information (International Social Science Council), 18 6, 903-13 DOI: https://doi. org/10.1177/053901847901800606

Elias, N. and Hammer, H. (1939). Über den Prozeß der Zivilisation. Vol. 2, pp. 367-367. Suhrkamp.

Fitz, J., Halpin, D. and Power, S. (1994), "Implementation research and education policy: practice and prospects", British Journal of Educational Studies, 42 1, 53-69 DOI: https://doi.org/ 10.1080/00071005.1994.9973983

Galindo-Rueda, F. and Van Cruysen, A. (2016), „Testing Innovation Survey Concepts, Definitions and Questions: Findings from Cognitive Interviews with Business Managers", OECD Science, Technology and Innovation Technical Paper, Paris. DOI: https://doi.org/10.4337/9780 857933652.00019

Graff, J. (26/04/2004), Our list of the most influential people in the world today, Artists \& Entertainers Ferran Adrià. The Time Online http:// content.time.com/time/specials/packages/article/0,28804,1970858_1970890_1971358,00. html [accessed 10/15/2018].

Giuri, P. and Mariani, M. (2006), Everything you always wanted to know about inventors (but never asked): Evidence form the PatVal-EU survey (No. 2005/20). LEM Working Paper Series 1-36

Glaser, M. A. and Clark, N. A. (1992), "Melting and liquid structure in two dimensions", Advances in chemical physics, 83 543-709 DOI: https:// doi.org/10.1002/9780470141410.ch7

Harrington, R. J. (2004), "The environment, involvement, and performance: implications for the strategic process of food service firms", International Journal of Hospitality Management, 23 4, 317-41 DOI: http://dx.doi. org/10.1016/j.ijhm.2003.12.004

Harrington, R., K. Chathoth, P., Ottenbacher, M., \& Altinay, L. (2014), „Strategic management research in hospitality and tourism: past, present and future", International Journal of Contemporary Hospitality Management, 26 5, 778-808 DOI: http://dx.doi.org/10.1108/ijchm-12-20130576

Heighton-Ginns, Laura: (12/10/2018) The business behind Michelin stars. https://www.bbc. com/news/business-45733941 BBC Online [accessed 03/10/2019].

Jenkins, A. (17/09/2017), "Nadine Levy Redzepi: What do you cook for the world's best chef?" https:/www.theguardian.com/lifeandstyle/2017/sep/17/nadine-levy-redzepi-nomawhat-to-cook-for-the-worlds-best-chef The Guardian Online [accessed 10/3/2019]

Keszeg, V. (2011), „Gasztronómia és emlékezet”, Erdélyi Múzeum, 73 1, 177-88

Kirk, J., Miller, M. L. (1986), Reliability and validity in qualitative research (Vol. 1), Sage, DOI: http://dx.doi.org/10.4135/9781412985659 
Kivela, J. \& Crotts, J. C. (2006), „Tourism and gastronomy: Gastronomy's influence on how tourists experience a destination", Journal of Hospitality \& Tourism Research, 30 3, 354-77 DOI: https://doi.org/10.1177/1096348006286797

Krugman, P. R. (2000), "Technology, trade and factor prices", Journal of International Economics, 50 1, 51-71 DOI: http://dx.doi.org/10.1016/ s0022-1996(99)00016-1

Law, K. (13/10/2016), "Italian super-chef Massimo Bottura on the power of leftovers", https://www. standard.co.uk/lifestyle/london-life/italian-superchef-massimo-bottura-on-the-power-of-leftovers-a3368331.html Standard U.K. Online [accessed 10/15/2018]

Lévi-Strauss, C. (1968). L'Origine des manières de table (1968, The Origin of Table Manners, trans. John Weightman and Doreen Weightman, Harper \& Row, Publishers, New York, 1979). pp: 284-310;

Magyar Gasztronómiai Egyesület (MGE) Kulináris Charta 2007/06/09 https://www.buvosszakacs. com/kulinaris-charta/ [accessed 10/15/2018]

Mayring, P. (2000), „Qualitative Content Analysis“, Forum Qualitative Sozialforschung / Forum Qualitative Social Research, $12 \mathrm{http}: / / \mathrm{www}$. qualitative-research.net/index.php/fqs/article/ view/1089/2385\%3E

Mennell, S. (1996), All manners of food: eating and taste in England and France from the Middle Ages to thpresent, University of Illinois Press, DOI: https://doi.org/10.2307/590730

Michelin-csillagot kapott a Costes étterem (2010.03.16.) https://index.hu/kultur/elet$\bmod / 2010 / 03 / 16 / \mathrm{megvan}$ az_elso_magyar_michelin-csillagos_etterem/ $/$ [accessed 21/01/2019].

Mitev, A. Z. (2012), „Grounded theory, a kvalitatív kutatás klasszikus mérföldköve", Vezetéstudomány, 43 1, 17-30

Molnár B. T. 01/30/2012), A magyar konyha nem világhírü http://hir6.hu/cikk/61887/molnar_b tamas a magyar konyha nem vilaghiru [accessed 12/15/2018]

Ottenbacher, M. and Gnoth, J. (2005), "How to develop successful hospitality innovation", Cornell Hotel and Restaurant Administration Quarterly, 46 2, 205-22 DOI: https://doi. org/10.1177/0010880404271097

Pieterse, J. N. (1995), "Globalization as Hybridization", In M. Featherstone, S. Lash, \& R. Robertson (Eds.), Global modernities (45-68), Thousand Oaks, CA: Sage DOI: http://dx.doi. org/10.4135/9781446250563.n3
Prahalad, C. K. and Ramaswamy, V. (2004), "Co-creation experiences: The next practice in value creation", Journal of Interactive Marketing, 18 3, 5-14 DOI: https://doi.org/10.1002/ dir. 20015

Rechnitzer J. - Lengyel I. (2000), „A városok versenyképességéröl”, In: Rechnitzer J. - Horváth Gy. (szerk.): Magyarország területi szerkezete és folyamatai az ezredfordulón. MTA Regionális Kutatások Központja, Pécs, 130-52

Schumpeter, J. A. (1939), Business cycles Vol. 1. New York: McGraw-Hill

Scott, A. J. (2000). The cultural economy of cities: Essays on the Geography of ImageProducing Industries, Sage. DOI http://dx.doi. org/10.4135/9781446217481

Surlemont B, Johnson C.. (2005), "The role of guides in artistic industries: The special case of the "star system" in the haute-cuisine sector", Managing Service Quality: An International Journal, 15 6, 577-90 DOI: http://dx.doi. org/10.1108/09604520510634032

Svejenova, S., Mazza, C. and Planellas, M. (2007), "Cooking up change in haute cuisine: Ferran Adrià as an institutional entrepreneur", Journal of Organizational Behavior: The International Journal of Industrial, Occupational and Organizational Psychology and Behavior, 28 5, 53961 DOI: http://dx.doi.org/10.1002/job.461

Technomic (2018), 2017 Value \& Pricing Consumer Trend Report (Winsight LLC.) https:// www.technomic.com/available-studies/ consumer-trend-reports/value-and-pricing [accessed 3/10/2019]

Tomlinson, J. (1999). Globalization and culture. University of Chicago Press.

Törőcsik M. (2010), „Életstílust kifejező ételfogyasztás, a food-trendek hatása", Korunk, 3, 58-65

Törőcsik M. (2011), Fogyasztói magatartás: Insight, trendek, vásárlók, Akadémiai Kiadó

Törőcsik M. (2016), „A fogyasztói magatartás új tendenciái”, Vezetéstudomány - Budapest Management Review, 47 4, 19-25

Zarlenga, M. I., Ulldemolins, J. R. and Morató, A. R. (2016), "Cultural clusters and social interaction dynamics: The case of Barcelona," European Urban and Regional Studies, 23 3, 422-40 DOI: https://doi.org/10.1177/0969776413514592

Miklós Ilona, PhD hallgató ilona.miklos@uni-corvinus.hu Budapesti Corvinus Egyetem Gazdálkodástudományi Kar 



\title{
A fütéstechnikai termékek marketingsajátosságai, avagy minőségértékelési jellegzetességek a vásárlási döntési folyamatban
}

\author{
Munkácsi Noémi \\ Budapesti Műszaki és Gazdaságtudományi Egyetem
}

\begin{abstract}
A TANULMÁNY CÉLJA
A magas müszaki intenzitású, fogyasztói termékek kategóriájába tartozó fütéstechnikai termékek kiválasztása során a fogyasztók az elkövetkező 15-20 évre vonatkozó, befektetés jellegü döntést hoznak. A kutatás célja feltárni ezen vásárlási döntési folyamat marketingsajátosságait, azonosítva a minőséget meghatározó értékelési tényezőiket, illetve az ahhoz kapcsolt márkákat, amelyeket a fogyasztók a döntési folyamat különböző szintjein észlelnek. További cél egy korábbi - a fütéstechnikai termékek végfelhasználói márkaválasztására irányuló - szakértői megkérdezés eredményének tovább gondolása és a jelen, a minőség szerepére összpontosító kutatás eredményeinek ütköztetése.
\end{abstract}

\section{ALKALMAZOTT MÓDSZERTAN}

A marketingsajátosságok és a minőségi tényezők feltárása céljából egy kétlépcsős primer kutatás került lefolytatásra 2013 decemberében a magyar lakosság körében, fogyasztókkal készített mélyinterjúk és online kérdőives felmérés formájában.

\section{LEGFONTOSABB EREDMÉNYEK}

A primer kutatás eredményei szerint a válaszadók a vásárlási döntési folyamat több szintjén észlelnek a fogyasztói és az ipari piacra vonatkozó, minőségértékelési tényezőket. A fogyasztók a végső döntés meghozatalakor az ár-érték arány tényezőjét és a megbízhatóságot tartják a legfontosabbnak, mely igazolja a korábbi szakértői megkérdezés feltételezését, és mely cáfolja a szervizes szakemberek fogyasztókról alkotott, ezen vonatkozású elképzelését. A válaszadók számos márkát érzékelnek a magyar fútéstechnikai piacon a vásárlási döntési folyamat különböző szintjein (a fütéstechnikai piac heterogén), azonban a márkák közötti differenciálás szintje alacsony.

\section{GYAKORLATI JAVASLATOK}

A fütéstechnikai termékeket gyártó vállalatok értékesítési- és marketing stratégiájának optimalizálása, a kutatás során feltárt minőségértékelési tényezők mentén.

Kulcsszavak: lakossági fütéstechnikai termékek, fogyasztói vásárlási döntés, minőségértékelés 


\section{BEVEZETÉS - A TÉMA AKTUALITÁSA}

A meleg az emberiség egyik alapvető szükséglete, melyet őseink a laktér közepén rakott nyílt tűz használatával állítottak elő és a tetőn vágott nyíláson át vezették el a keletkezett füstöt (Hansen 1999) Az első modern, központi fütési rendszert i.e. I. században a Római Birodalomban építették, melyben a kemencében elégetett égéstermék földalatti vezetékeken keresztül juttatta el a hőt, melyet aztán kéményeken keresztül vezettek el a szabadba (Cowan 1987). A XXI. században a fütéstechnikai rendszerek jelentőségüket tekintve messze túlmutatnak a hőtermelés lehetőségén: lakossági és ipari épületek stratégiai szintü energetikai rendszeréért (fütés, hűtés, szellőztetés, klimatizálás, klímakomfort) és fenntartható energiafelhasználásáért felelösek (Day et al. 2003).

A mai fütéstechnikai piac sokszínűségét és egyben marketing-szempontú kutatási sajátosságát több tényezö is jelzi. Egyrészt a számos piaci szereplő (pl. fogyasztók, szerelők, gyártók, értékesítők, tervezők, szerviz szakemberek, stb.), akik egyéni érdekeknek megfelelően befolyásolják a piac müködését; másrészt a diverzifikált termékválaszték (pl. hagyományos és kondenzációs gázkazán, olaj-, elektromos- és szilárdtüzelésü kazán, stb.) melyből a megfelelő fütéstechnikai termék kiválasztása történik. A fogyasztóknak számos kettősséggel kell szembe nézniük a fütéstechnikai termékek vásárlási folyamata során: pl. magas müszaki intenzitású és drága terméket vásárolnak alapvetö szükséglet (hö, meleg víz) kielégítése céljából. A magas beruházási költség, valamint a termék műszaki teljesítményével kapcsolatos bizonytalanság hatással vannak a vásárlási döntési folyamatra (Rai et al. 2016), a megvásárolt technológiára és márkára. Ezen bonyolult vásárlási döntési folyamat mentén a fogyasztó a termékminőséget „érzékeli és elismeri” (Vágási 2001, 95).

Jelent tanulmányban kétlépcsős fogyasztói megkérdezés során feltárásra kerültek a fogyasztói vásárlási döntési folyamat szakaszai, a minőség érzékelésének szintjei és tényezői, valamint a termékminőségi tényezőkhöz kapcsolt, fogyasztók által észlelt márkák. Míg a 2014-ben, szerzőtársaimmal publikált kutatásunk (Vágási és tsai 2014) a szerelő szakemberek megkérdezésével azonosította a fogyasztók számára fontos minőségértékelési tényezőket, addig jelen fogyasztói megkérdezés eredményeiből levont következtetések lehetőséget biztosítanak a korábbi kutatással való ütköztetésére, illetve a fogyasztói minőségérzékelés pontosabb megismerésére.

\section{A FÜTÉSTECHNIKAI TERMÉKEK MARKETINGSAJÁTOSSÁGAI A FOGYASZTÓI VÁSÁRLÁSI DÖNTÉSHOZATALBAN}

Marketing-termékklasszifikáció tekintetében a háztartási fütéstechnikai termékek olyan lakossági műszaki termékek, melyek alapvető kettősséget hordoznak magukban (Vágási és tsai. 2014). Egyrészt őrzik a tartós fogyasztási cikkek jellegzetességeit, erősen müszaki jellegúek, termékfejlesztésük a fenntarthatóság, az energiatakarékosság, szabványositás feltételeihez szabottak. Kiválasztásuk, tervezésük, szerelésük és karbantartásuk szakemberhez (szerelö, tervező) kötött. Emellett olyan napi használatú háztartási termékek, melyek az alapvetö emberi szükségletet (meleg víz, hőérzet) hivatottak szolgálni. A magas műszaki intenzitás és ipari jelleg, valamint az alapvető szükségletet kielégítő szerepkör kettőssége olyan sajátos marketingtulajdonságokkal ruházza fel a fütéstechnikai terméket, mely különböző kutatási céloknak ad teret a fogyasztói vásárlási döntéshozatalban.

A fütéstechnikai termékek marketingsajátosságait a nemzetközi tudományos szakirodalom több szempontból vizsgálta. ${ }^{1} \mathrm{~A}$ fogyasztói vásárlási döntési folyamatban felmerül az érzelmeken versus racionalitáson alapuló döntéshozatal kettősségének dilemmája. A fogyasztók energiatakarékos lakásfelújítással kapcsolatos döntéseiben nemcsak a racionalitás és a gyakorlatiasság, hanem a szimbolikus fogyasztás, a komfortérzet, a kívánt státus elemei is kiemelkedő szerepet játszanak (Aune 2007). Így a fütéstechnikai termékek gyártóinak nemcsa a konkurens márkákkal kell „versenyezniük”, hanem a dekoratív, esztétikai élményt nyújtó lakáselemek gyártóival (pl. konyhabútor, szaniter, csempe, stb.) is.

A racionális döntéshozatalt igazolja az is, hogy a fogyasztók a fütéstechnikai termékek vásárlását befektetés jellegü döntéshozatalnak tekintik (Kaezing \& Wüstenhagen 2008). Ebben az esetben

\footnotetext{
${ }^{1}$ Mivel jelen cikk a fogyasztói döntéshozatal sajátosságait vizsgálja a minőségértékelési tényezők tükrében, így a bemutatott marketingsajátosságok erre a vonatkozásra összpontosítanak, és nem terjednek ki pl. az ipari piac vonatkozásának vizsgálatára.
} 
akkor döntenek egy termék megvásárlása mellett (különös tekintettel az innovatív, megújuló energiákon alapuló energiatakarékos megoldások esetében), ha a befektetés megtérülése gyors. (Faiers et al. 2007) Wüstenhagen \& Kaezing (2010) szerint a fogyasztók energiatakarékos fütési megoldások vásárlásánál a kezdeti (befektetési) költségeket mérlegelik a müködési költségek függvényében.

A fütéstechnikai termékek további marketingsajátossága a bonyolult és megfontolt vásárlási döntési folyamat (Kaezing \& Wüstenhagen 2008), melyet az elmúlt években számos nemzetközi kutatás vizsgált. Ezen kutatások - többek között - Rogers (2003) innováció diffúziója elméletére alapulnak, és azt vizsgálják, hogy milyen tényezők mentén adaptálják a fogyasztók az egyes innovatív, energiatakarékos épületgépészeti megoldásokat. Ilyen diffúziós elméleten alapuló kutatások készültek különböző fütéstechnikai és egyéb energetikai megoldások ( $\mathrm{pl}$. napelem, napkollektor) esetében. Az 1. sz. táblázat ezen korábbi kutatásokat, illetve az adaptációt meghatározó tényezőként tekinti át.

\section{1. táblázat: Innovatív fütési megoldások adoptációjának befolyásoló tényezői a termékminőség tükrében}

\begin{tabular}{|c|c|c|}
\hline \multirow[t]{6}{*}{ Termékjellemzők } & $\begin{array}{l}\text { Energiaforrás fajtája } \\
\text { és költsége }\end{array}$ & $\begin{array}{l}\text { Fütéstechnikai termékek (Gustavsson, Joelsson 2007) } \\
\text { Központi fütés (Chen et al. 2012) }\end{array}$ \\
\hline & Fütésszabályozás & Távfütés (Wissner 2014) \\
\hline & $\begin{array}{l}\text { Befektetési és üzemel- } \\
\text { tetési költségek }\end{array}$ & $\begin{array}{l}\text { Innovatív fütési megoldások (Mahapatra, Gustavsson } \\
\text { 2010) } \\
\text { Fütéstechnikai rendszerek (Stolyarova et al. 2015) } \\
\text { Fa- és pellet tüzelésű kazánok (Rouvinen, Matero 2013) }\end{array}$ \\
\hline & Megbízhatóság & $\begin{array}{l}\text { Innovatív fütési megoldások (Mahapatra, Gustavsson } \\
\text { 2010; 2008a;b ) }\end{array}$ \\
\hline & Környezeti hatás & $\begin{array}{l}\text { Innovatív fütési megoldások (Mahapatra, Gustavsson } \\
\text { 2010; Stolyarova et al. 2015; Achtnicht 2011; Gustavs- } \\
\text { son, Joelsson 2007) } \\
\text { Központi fütés (Chen et al. 2012) }\end{array}$ \\
\hline & Beltéri levegőminőség & $\begin{array}{l}\text { Innovatív fütési megoldások (Mahapatra, Gustavsson } \\
\text { 2008b) }\end{array}$ \\
\hline \multirow[t]{3}{*}{ Támogatások } & Elérhetőség & $\begin{array}{l}\text { Fütési rendszerek (Mahapatra, Gustavsson 2008a; } \\
\text { Stolyarova et al. 2015) } \\
\text { Energiatakarékos fütés felújítás (Nair, Mahapatra 2011) } \\
\text { Lakossági fütési rendszerek (Michelsen, Madlener 2013) }\end{array}$ \\
\hline & Korlátok & $\begin{array}{l}\text { Napelem (Faiers et al. 2006) } \\
\text { Lakossági fütési rendszerek (Claudy et al. 2011) } \\
\text { Napelemes rendszerek (Strupeit, Palm 2016) }\end{array}$ \\
\hline & $\begin{array}{l}\text { Hozzáférhető } \\
\text { információ }\end{array}$ & $\begin{array}{l}\text { Energiatakarékos fütés felújítás (Nair, Mahapatra 2011) } \\
\text { Innovatív fütési megoldások (Mahapatra, Gustavsson } \\
\text { 2010) }\end{array}$ \\
\hline
\end{tabular}

Forrás: saját szerkesztés 
Megállapítható, hogy bizonyos technológiák sikeres adaptációjában az energia fajtája, költsége, szabályozhatósága és megbízhatósága, valamit az elérhető támogatások játszották a fő szerepet. Ezen korábbi kutatások szerint a fogyasztók a különböző termékjellemzőket értékelő kritériumként észlelték a vásárlási döntési folyamat során. Ezek egyrészt gazdasági tényezők voltak: befektetési költségek (Mahapatra \& Gustavsson 2008a; 2010; Tapaninen et al. 2009a), müködési költségek (Wüstenhagen \& Kaezing 2010), ár-érték arány és garancia (Stolyarova et al. 2015). Másrészt müszaki tényezők: megbízhatóság (Mahapatra, Gustavsson 2008a; 2010) és komforttényezők (Mahapatra, Gustavsson 2008a), harmadrészt pedig kockázati tényezők, melyek a megfizethetőségre (Tapaninen et al. 2009a;b), a szolgáltatás megbízhatóságára (Mahapatra, Gustavsson 2008a), illetve a társadalmi környezet elfogadására (Tapaninen et al. 2009b) irányultak.
A korábbi szakirodalmi kutatásokat figyelembe véve, valamint a fütéstechnikai termékek jellemzőiben fellelhető ipari és fogyasztói piaci jellegzetességek kettősségére alapozva, a 2. sz. táblázat mutatja be a fütéstechnikai termékek vásárlási döntési folyamatát. Feltételezem, hogy a fogyasztói döntéshozatali folyamat olyan ipari döntési sajátosságokkal egészül ki (2. táblázatban vastagon keretezett rész), mint pl.:

- a fütéstechnikai termékekkel szembeni igény leírása (pl. a lakótérnek megfelelö paraméterezés, a fogyasztás szabályozása, stb.)

- a termékkel szembeni elvárt jellemzők meghatározása (pl. energiatakarékosság, teljesítmény)

- a beszerzési források meghatározása illetve az ajánlatkérés (szerelő szakember kiválasztása, ár, kedvezmények, támogatási lehetőségek, szállítási feltételek, készlet, fizetési feltételek, stb.)

\section{2. táblázat A fütéstechnikai termékek feltételezett vásárlási döntési lépései}

\begin{tabular}{|c|c|c|}
\hline $\begin{array}{l}\text { A fogyasztói vásárlási } \\
\text { döntés lépései }\end{array}$ & $\begin{array}{c}\text { A fütéstechnikai termékek } \\
\text { feltételezett vásárlási döntés } \\
\text { lépései }\end{array}$ & $\begin{array}{c}\text { Az ipari beszerzési döntés } \\
\text { lépései }\end{array}$ \\
\hline \multirow[t]{3}{*}{ 1. A probléma felismerése } & 1. A probléma felismerése & 1. A probléma felismerése \\
\hline & 2. Az igény általános leírása & 2. Az igény általános leírása \\
\hline & $\begin{array}{l}\text { 3. A termékjellemzők megha- } \\
\text { tározása }\end{array}$ & $\begin{array}{l}\text { 3. A termékjellemzők meghatá- } \\
\text { rozása (specifikációk) }\end{array}$ \\
\hline \multirow[t]{2}{*}{ 2. Információgyüjtés } & $\begin{array}{l}\text { 4. Aktív termék- és potenciális } \\
\text { beszerzési forrásra vonatkozó } \\
\text { információgyüjtés }\end{array}$ & $\begin{array}{l}\text { 4. A potenciális beszerzési } \\
\text { források (szállítók keresése) }\end{array}$ \\
\hline & 5. Ajánlatkérés & 5. Ajánlatkérés \\
\hline 3. Alternatívák értékelése & 6. Alternatívák értékelése & $\begin{array}{l}\text { 6. Az ajánlatok értékelése és a } \\
\text { szállítók kiválasztása }\end{array}$ \\
\hline 4. Vásárlás & 7. Megrendelés, vásárlás & 7. Megrendelés \\
\hline 5. A vásárlás értékelése & 8. A vásárlás értékelése & 8. A teljesítés értékelése \\
\hline
\end{tabular}

Forrás: Munkácsi - Grőger 2011, Vágási 1998 alapján 
A fogyasztói magatartás szakirodalma szerint a fogyasztók a vásárlási döntési folyamat során a minőséget különböző minőségértékelési tényezők mentén érzékelik. A fütéstechnikai termékek feltételezett minőségértékelési tényezőit a fogyasztói (Garvin 1988) és ipari (Hart 1989) termékek termékminőségi alkotóelemeinek összevetésével határoztam meg, melyet szerzőtársaimmal a 2014-ben megjelent kutatásunkban mutattunk be. (Vágási és tsai. 2014) A tartósság, a megbízhatóság, a stílus és design olyan ismérvek, melyek mind a fogyasztói, mind pedig az ipari piac termékeire jellemzőek, így feltételezésem szerint a fütéstechnikai termékek esetében is jellemző. Továbbá úgy vélem, a fütéstechnikai termékek olyan további ipari minőségértékelési ismérvekkel egészülnek ki, mint pl. műszaki jellemzök, a könnyü használat, stb. Továbbá feltételezem, hogy a fogyasztók a vásárlási döntési folyamat során különböző fütéstechnikai márkákat észlelnek, melyeket az észlelt minőségi tényezőkkel azonosítanak. Fütéstechnikai termékek fogyasztói márkaválasztási preferenciájára vonatkozó, minőségértékelés tekintetében folytatott kutatást a szakirodalomban nem találtam, így az empirikus kutatásom során kerül ez a feltételezés igazolásra, feltárásra.

A jelen tanulmány célja, hogy a szakirodalmi feltárást követően a gyakorlatban is vizsgálja a fogyasztói vásárlási döntési folyamatának különböző lépéseit, azonosítsa az érzékelt termékminőség szintjeit, tényezőit és az azok kapcsán észlelt márkákat a magyar fütéstechnikai piacon. A kutatás a 2014-ben megjelent, szakértői megkérdezés eredményeit taglaló kutatás egy következő lépésének tekinthetö, melynek eredményei a fogyasztói megkérdezés eredményeivel az összefoglaló részben kerül összevetésre és kiértékelésre.

\section{A FOGYASZTÓI MEGKÉRDEZÉS EREDMÉNYEI}

Az empirikus kutatáshoz szükösen rendelkezésre álló szakirodalmi forrás alapján, a fogyasztói vásárlási döntési folyamat lépéseinek, illetve a termékminőség szintjeinek és tényezőinek vizsgálatához kétlépcsős (kvalitatív, majd kvantitatív) primer kutatási koncepciót alkalmaztam.

\section{Kutatási koncepció és módszer}

A primer kutatás első lépéseként páros mélyinterjút készítettem ingatlantulajdonos ( 9 ház- és 1 lakástulajdonos) házaspárokkal Nyugat-Magyarországon 2013 őszén. Az interjúk elsődleges célja, hogy feltárja a fogyasztói vásárlói döntéshozatal lépéseit és a minőség érzékelésével kapcsolatos jellegzetességeit (szintek és tényezők). Összességében 10 interjú került lefolytatásra 32-70 év közötti házaspárokkal. A megkérdezettek között 6 pár rendelkezett korábbi vásárlási tapasztalattal, 4 pár pedig elsőként vásárolt fütéstechnikai készüléket. Müszaki megoldás tekintetében hagyományos és kondenzációs kazánt, szilárdtüzelésủ kazánt, cserépkályhát vásároltak a megkérdezettek újépítés vagy fütéskorszerüsítés céljából. A mintavételhez a hólabda módszert alkalmaztam, az interjúk kiértékelése pedig az Nvivo 10 programmal, interjúvázlat és készített jegyzetek segítségével történt. A mélyinterjúk eredményei a második lépcsős, kvantitatív kutatás alapjául szolgáltak.

$\mathrm{Az}$ online kérdőívek 2013 decemberében kerültek kitöltésre a magyar lakosság körében. $\mathrm{Az}$ alapsokaságot az Ipsos Interactive Services online panelja biztosította, a Bosch Thermotechnik $\mathrm{GmbH}$. finanszírozásában. A panel a magyar, 18 éven felüli, internettel rendelkező lakosságot reprezentálja, azonban a reprezentativitás a magyar potenciális fütéstechnikai vásárlói sokaságra nem garantálható. Összességében 417 kérdőív került teljességében kitöltésre. A válaszadók saját ingatlannal rendelkeznek és az elmúlt, ill. elkövetkező 18 hónapban fútéstechnikai terméket vásároltak/ szándékoznak vásárolni.

\section{A páros mélyinterjúk eredményei}

A mélyinterjúk résztvevői minden esetben saját tulajdonnal rendelkező (családi ház, lakás) házaspárok, akik legalább egy alkalommal vásároltak saját maguk részére fütéstechnikai berendezést. A mélyinterjú eredményeit a 1. ábra szemlélteti. 


\section{1. ábra: Minőségi ismérvek és a márkaészlelés a fogyasztói vásárlási döntési folyamat egyes szakaszaiban}

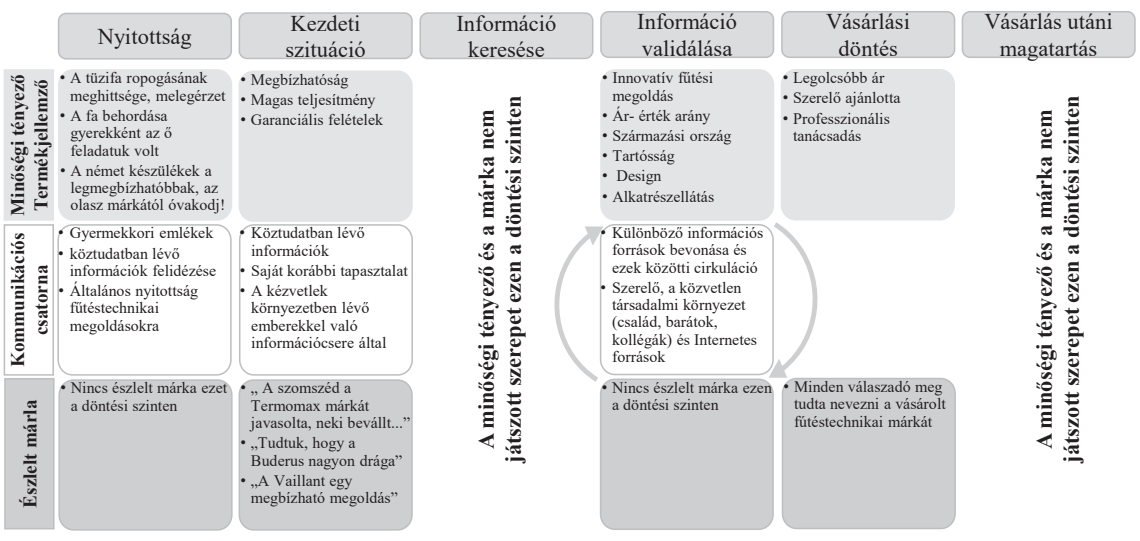

Forrás: saját szerekesztés

A válaszadók az alábbi vásárlási döntési szinteket említették: (a) nyitottság, (b) kezdeti vásárlási szituáció, (c) információ keresése (d) információ validálása (e) vásárlási döntés (f) vásárlás utáni magatartás. A minőség észlelése (a) a nyitottság, (b) a kezdeti vásárlási szituáció, (d) az információ validálás és (e) a vásárlási döntés szintjein történt. A megkérdezettek a minőségi tényezőket termékjellemzők formájában észlelték, melyek a vásárlási döntési folyamat eltérő szakaszaiban különböző szerepet játszottak. A válaszadók továbbá a minőségi tényezők információs forrásával és az észlelt márkákkal kapcsolatban hívtak elő emlékeket.

A megkérdezettek a vásárlási folyamat kezdetén nyitottságukat fejezték ki a fütéstechnikai termékekkel kapcsolatban, mely az egész vásárlási döntési folyamat során jelent volt: fontosnak tartják az új müszaki megoldások ismeretét. Példákat hoztak korábbi (gyermekkori) emlékeikből és/ vagy a köztudatban lévő információkból. Azonban sem konkrét hirdetést, sem márkát nem tudtak megnevezni a vásárlási döntési folyamat ezen szakaszában. A válaszadók a minőségi tényezőkhöz, technológiákhoz (kandalló, fatüzelésủ kazán, stb.) pozitív érzelmeket és élményeket kapcsolnak (a ropogó tűz ereje, a közös családi élmények, a tüzrakás gyermekkori feladat volt, stb.)

Amint a kezdeti vásárlási szituáció fennáll, és a fogyasztó eldönti, hogy új fütéstechnikai terméket vásárol, a minőségi tényezők szerepe az új termékkel szembeni elvárásokban mutatkozik meg.
Ebben a szakaszban a megbízhatóság, a teljesítmény és a garanciális feltételek kerültek említésre. A megkérdezettek saját korábbi tapasztalatukra illetve a társadalmi környezetből érkező ismeretekre, mint információs forrásokra hagyatkoztak, melyek minőségi tényezőkkel kapcsolatos márkainformációt közvetítettek. (a Buderus drága márka, a Vaillant megbízható, stb.)

Az információkeresés szakaszában a házaspárok nagyrészt maguk kezdték meg a keresést (hat pár) az interneten, különböző gyártói weboldalakon és információs portálokon. Ezen a döntési szinten nem tudtak a válaszadók emlékeket felidézni termékjellemzőkkel, illetve márkákkal kapcsolatban. Mind a 10 pár határozottan állította, hogy ezen a szinten nem hoztak vásárlási döntést, hanem a megszerzett információt számos más forrással validálták. Ez az értékelő folyamat kb. 4-6 lépésből állt, melyben a megkérdezettek tapasztalatot cseréltek számos kommunikációs csatorna bevonásával. Ahogy az egyik pár mesélte: "Elsö körben az Interneten nézelődtünk lehetséges megoldások után, hiszen számunkra fontos volt, hogy a szerelővel konkrét elképzelésekről egyeztessünk. A szerelő által javasolt terméknek különbözö blogokon és fórumokon olvastunk utána, baráti körben, valamint a munkahelyen kollégáknál kérdeztünk utána..." A válaszadók a folyamat bonyolultságát, és az információk értékelésének nehézségét hangsúlyozták. Számos termékjellemző (ipari és lakossági termékek minőségi tényezői) került felsorolásra a validálás során, melyben sem prioritás, sem 
hangsúlyi eltérés nem volt érzékelhető, pl. megbízhatóság, tartósság, ár-érték arány, garanciális feltételek, alkatrészellátás és költsége, stb.

A vásárlási döntésben a válaszadók szerint a legolcsóbb ár játszotta a fö szerepet (4 házaspár esetében), 3-an a szerelő tanácsára cselekedtek, 3-an pedig a leginkább magas szintü szaktanácsadás helyszínén vásárolták a terméket. Minden válaszadó házaspár meg tudta nevezni a megvásárolt terméket/ márkát (említés száma): Junkers (3), Termomax (3), Vaillant (2), Eta (1), Etna (1).

\section{Az online kérdőives megkérdezés eredményei}

Mivel a páros mélyinterjú megkérdezettjei a nyitottság szintjén számos információt hívtak elő a köztudatból a fütéstechnikai termékekkel kapcsolatban, így nyitott kérdés formájában erről kérdeztem a válaszadókat. Összesen a 417 megkérdezett, 251 válaszából a 149 db értékelhető választ érkezett. Számos fütéstechnikai technológiával (39\%), márkával (23\%), tüzelőanyaggal $(19 \%)$, a termék származási helyével $(13 \%)$ és költségekkel $(6 \%)$ kapcsolatos ismeret él a köztudatban. Ezekhez a müszaki megoldásokhoz és márkákhoz minőségi ismérveket társítottak a fogyasztók: pl. legjobb megoldás, leghatékonyabb, megbízható, egyszerü és kényelmes, rossz minőségü, nem térül meg, drága, hatékony, modern, stb.

A válaszadók fütéstechnikai termékekre vonatkozó ismeretét a fütéstechnikai termékekkel kapcsolatos reklámok felidézésével vizsgáltam. $74 \%$ egyáltalán nem emlékezett, $14 \%$ az elmúlt 2 hónapból, $12 \%$ az elmúlt 3 hónapból vagy annál régebbről. Azt a 107 (26\%) válaszadót, akik emlékezni tudtak valamilyen fütéstechnikai termékekre vonatkozó hirdetésre, tovább kérdeztem a hirdetésben szereplő műszaki megoldásról.
A megújuló energiákon alapuló fütéstechnikai és energetikai megoldások (napelem, napkollektor, hőszivattyúk $40 \%$ felett) magas említésszámot kaptak, melyekhez leginkább a Bosch márkát társítják a válaszadók (19\%). A Junkers márkát a válaszadók $8 \%$-a (5. hely), a Buderus márkát a válaszadók 6\%-a (6. hely) említette, melyek alacsony említésszámnak felelnek meg. Számos márka kapott hasonlóan alacsony említési számot (3\% vagy alatta), mely szerint több márka él a válaszadók tudatában. A „nem emlékezők” aránya a második helyen szerepel, mely egy magas említési számnak felel meg a reklámra emlékezők körében.

A kezdeti vásárlási szituáció szintjén a megkérdezettek a minőségértékelési tényezőket az új fütéstechnikai termékkel szemben támasztott elvárásként kezelték. A megkérdezettek nagy többsége számos tényezőt tartott fontosnak, többek között a tartósság (95\%), a megbízhatóság (95\%), az ár-érték arány $(92 \%)$, a garancia $(85 \%)$ és a szervizszolgáltatás (72\%) fontosságával értett egyet. Ezen a döntési szinten is a Bosch (23\%) és a Vaillant $(13 \%)$, valamint a tradicionális magyar márka, a Hajdu (12\%) feleltek meg az fogyasztók elvárásainak. A Junkers márkát a válaszadók $9 \%$-a választotta (4. hely), míg a Buderus márka a válaszadók 3\%-a szerint felel meg az elvárásoknak. A megkérdezettek 7\%-a nem tudott ezen a döntési szinten márkát felidézni

Az információ validálása szintjén a válaszadók $85 \%$-a validálta a megszerzett információt, ezen válaszadók közel 50\%-a további 1-3 alkalommal, $30 \%$-a pedig 4-6 alkalommal tette mindezt. A validálás forrásai között szerepel a szerelö, különböző Internetes források (gyártói weboldalak, online információs portálok, blogok és fórumok, stb.), család, barátok és egyéb, a fogyasztó társadalmi környezetéhez tartozó szereplő. A végső márkaválasztás eredményét a 2. összefoglaló ábra szemlélteti. 


\section{2. ábra: A minőségértékelési tényezők és márkák szerepe a vásárlási döntés szakaszában}

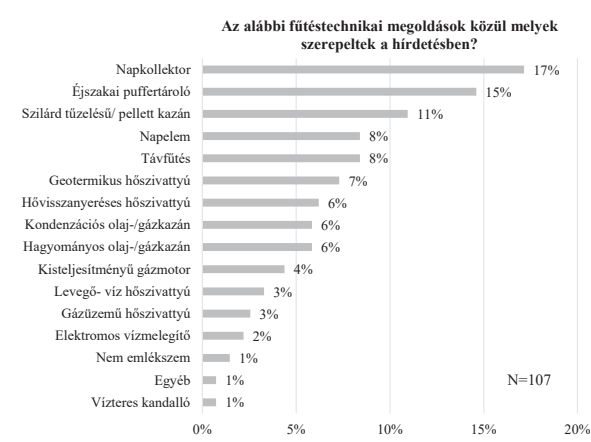

Forrás: saját szerkesztés

A végső döntésnél a válaszadók a Bosch (23\%), majd a Hajdu (14\%) és a Vaillant 13\%) márkák között hezitáltak, a megvásárolt termék márkájára azonban $23 \%$ nem emlékszik. A választást eldöntő tényező a megkérdezettek 39\%-a szerint az árérték arány volt, a megbízhatóságot a válaszadók harmada jelölte meg. A korábbi vásárlási döntési folyamat szintjein fontosnak ítélt tényezők, pl. a készülék tartóssága, az alkatrész-ellátottság és költsége, a garanciális feltételek, stb. a végső döntés és a márkaválasztás szintjén egyáltalán nem, vagy csak elenyésző mértékben játszanak szerepet.

\section{MEGÁLLAPÍTÁSOK}

A 2014-ben közölt szakértői megkérdezésben (Vágási és tsai. 2014) a fogyasztói piac Garvin-féle minőségtényezőit vettük alapul, és ezek fogyasztói megítélését szerviz szakemberek megkérdezésével a Bosch, Buderus és Junkers márkák kapcsán vizsgáltuk. Akkori feltételezésünk, mely szerint a fogyasztók a vásárlási döntés meghozatala során az ár-minőség viszonyát tartják a legfontosabb értékelő ismérvnek, a szakértők véleménye szerint nem igazolódott be. A szakértők szerint a fogyasztók a szervízszolgáltatást, a megbízhatóságot valamint a termék garanciális idejét tartják a legfontosabb döntési ismérvnek. A fogyasztói megkérdezés eredményei azonban igazolják korábbi feltételezést, mely szerint a fogyasztók legnagyobb része (39\%-a) ténylegesen az ár-érték arányt tartja a márkaválasztás döntő ismérvének.

Továbbá a 2014-ben megjelent kutatásban feltételeztük, hogy a magyar piac három vezető márkája(Bosch, Buderus, Junkers) egy-egyminőségi

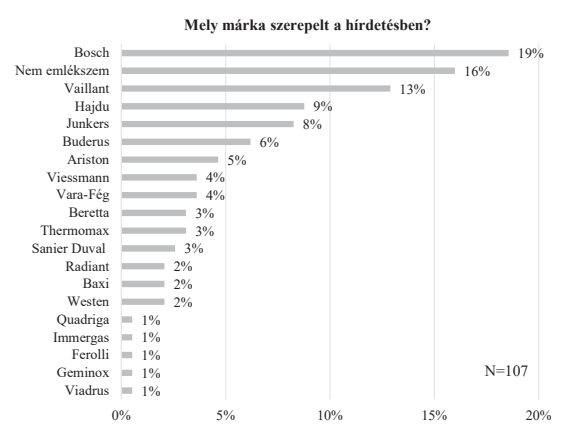

ismérvhez rendelhetőek: a Buderus márkánál a megbízhatóság, a Bosch márkánál a szervízszolgáltatás, a Junkers márkánál az ár-minőség tényezője dominál. A szakértői megkérdezés eredménye szerint mind a három márka esetében a szervízszolgáltatás kapta a legmagasabb említési számot, így az akkori feltételezek nem igazolódtak be. Megemlítendő, hogy a szervizes szakemberek egyszerre több márkát is képviselnek Magyarországon

A fogyasztói megkérdezés eredményei szerint a fogyasztók a vásárlási döntési folyamat különböző szintjén érzékelik a minőséget és a márkákat, azonban fütéstechnikai reklámra a fogyasztók csak kis csoportja emlékezett. A kezdeti vásárlási szituáció a tartósság, a megbízhatóság, az ár-érték arány, a műszaki paraméterek, a garanciával és a könnyü használat mentén észlelték a válaszadók a minőséget. A validálás és a végső döntés szintjén pedig az ár-érték arány és a megbízhatóság játszotta a döntő szerepet. A korábban fontosnak tartott tartósság, az alkatrész-ellátottság, a garanciális feltételek illetve a könnyü használat egyáltalán nem került választásra vagy csak elhanyagolható súllyal (pár \%-ban).

A márkaészlelés tekintetében a 3. összefoglaló ábra 2014-ben megjelent kutatáshoz hasonlóan a Junkers, Buderus és Bosch márkákat teljesítményét szemlélteti, legjelentősebb piaci versenytársuk, a Vaillant és Viessmann mellett. A \%-os értékek az egyes márkák említési gyakoriságát jelölik, a számok pedig a márkák említési rangsorát mutatják. 


\section{3. ábra. Márkaészlelés a vásárlási döntési folyamat mentén}

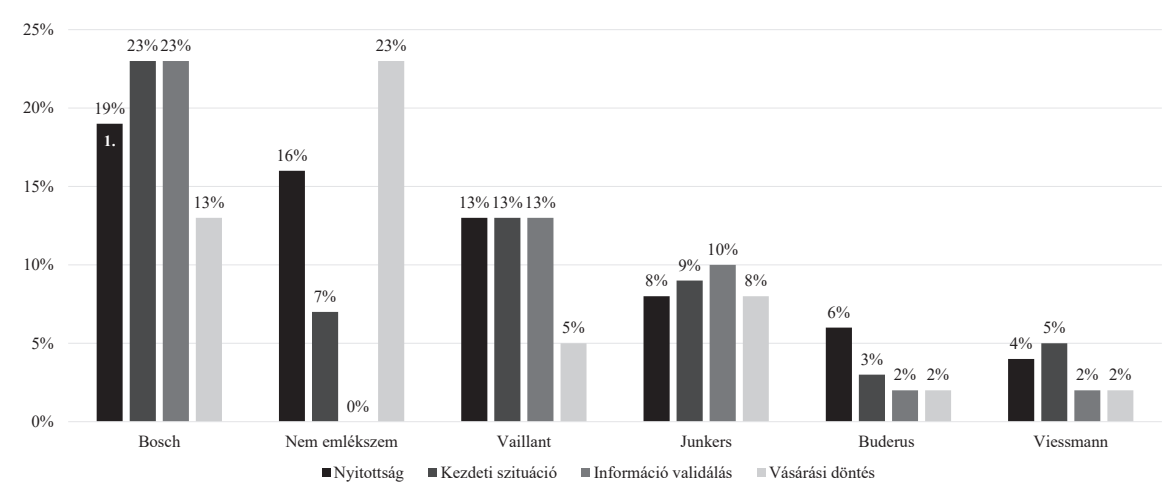

Forrás: saját szerkesztés

A vásárlási döntési folyamat során számos (magyar és nemzetközi) márka kapott közel hasonló (alacsony) említési gyakoriságot, mely a magyar fütéstechnikai piac heterogenitására utal. Továbbá úgy vélem, hogy az eredmények tekintetében a márkák nehezen diverzifikálhatók, így az a termék kerül megvásárlásra, mely az ár-érték arány, mint minőségtényező tekintetében a legjobban teljesít.

A Bosch márka megtartotta a vezető helyét a vásárlási döntési folyamat során, a legmagasabb említésszám mellett is csak a válaszadók 23\%-a említette. A márkák a végső döntés szakaszában szóródtak a leginkább, itt a Bosch márka 13\%-al végzett a második helyet, mivel a fogyasztók legnagyobb aránya nem emlékezett a vásárolt termék márkájára. A Junkers márka a vásárlási döntési folyamat mentén végig megtartotta 4. helyét, a Boschnál jóval alacsonyabb említési számmal. Mindkét márka legjelentősebb piaci versenytársa, a Vaillant márka 13\%-al a vásárlási döntési folyamat mentén a 2 . illetve a 3 . helyen szerepelt, a végső döntés szakaszában jelentősen pozíciót vesztett. Ennek oka lehet, hogy az ár-érték arány, illetve a megbízhatóság tekintetében rosszul szerepel. A Buderus márkát viszonylag többen említették a nyitottság szakaszában, azonban a teljes vásárlási döntési szakasz során alacsony rangsorolást kapott. Véleményem szerint a Buderus márka magas árfekvése okán (magas minőségének észlelése ellenére) kerül elutasításra. A Viessmann márka a Buderushoz hasonlóan összességében alacsony említésszámot kapott, mely a hasonlóan magas árfekvéssel magyarázható.

\section{ÖSSZEGZŐ KÖVETKEZTETÉSEK ÉS JAVASLATTÉTEL}

Az empirikus feltáró kutatásom megkérdezettjei komplex és bonyolult vásárlási folyamatként érzékelték a fütéstechnikai termékek vásárlását. Bár a fogyasztók általános nyitottságot mutattak számos fütéstechnikai megoldás, technológia, márka és minőségi tényező iránt, a végső döntésnél a korábban vélt tényezők fontossága érvényét vesztette. Feltételezhető, hogy a magyar fütéstechnikai piac nagyban heterogén, sok márka több terméke verseng a fogyasztók döntéséért, melyben az árérték arány és a megbízhatóság játssza a legfontosabb szerepet. Amennyiben valamely márka nem tudja tartani versenyelönyét e két legfontosabb tényező tekintetében, úgy a fogyasztók részéről elutasításra kerül.

Ahogy 2014-es szakértői megkérdezés és jelen tanulmány eredményeinek ütköztetése során megállapítottam, hogy a fogyasztók más minőségértékelési tényezőket tartanak fontosnak a végső döntés alkalmával, mint ahogy a szakemberek a fogyasztókról gondolnák. Ez alapvető kérdést vet fel a gyártók értékesítési-és marketingstratégiájában. A vállalatok rendszerint a szerelő és szervizes szakembereket tekintik elsődleges célcsoportjuknak és hagyatkoznak arra, hogy a gyártó termékét népszerüsítsék és ajánlják tovább a fogyasztók felé. Azonban a magyar fütéstechnikai piacon egy szerelö egyszerre több fütéstechnikai márkát is képvisel a fogyasztók felé, így amennyiben a szerelő rosszul méri fel a fogyasztói igényeket, úgy a márkák és technológiák ajánlásának hitelessége mind a fogyasztók, mind pedig a gyártók 
szemszögéből kérdésessé válik. Feltételezhető, hogy ennek okán bizalmatlanság alakulhat ki a fogyasztókban, hogy vajon a szerelő szakember ténylegesen a fogyasztói igényeknek (minőségi tényezőknek) megfelelő márkát javasolja, az amúgy is komplexnek és bonyolultnak itélt vásárlási döntési folyamat során. Ezzel magyarázható a validálási szakasz hozza, illetve az internetes források jelentősége a vásárlási döntési folyamatban.

A fütéstechnikai termékeket gyártó vállalatok részére javaslom, hogy aktív márkaépítés és márkaismertség helyett, a fogyasztó számára fontosnak vélt minőségi ismérvek mentén határozza meg marketingkommunikációs eszközrendszerét és koncentrálja költségvetését. Javasolom, hogy talán az eddig hatékonynak vélt szerelői illetve hagyományos kommunikációs csatornákat (pl. újsághirdetés, rádiós és tévés kampányok, kiállításokon való megjelenés, stb.) váltsák fel a fogyasztó számára hitelesnek tartott közvetítői csatornák, melynek pontosabb meghatározásához és azonosításához további feltáró kutatás szükségességét látom a megfelelö fogyasztói kör megkérdezésének segítségével.

\section{HIVATKOZÁSOK}

Achtnicht, M. (2011), "Do environment benefits matter? Evidence from a choice experiment among house owners in Germany", Ecological Economics, 70 11, 2191-200 DOI: https://doi. org/10.1016/j.ecolecon.2011.06.026

Aune, M. (2007), „Energy comes home”, Energy Policy, 35 5457-65 DOI: https://doi. org/10.1016/j.enpol.2007.05.007

Chen, C., Zheng, Y., Mu L. (2012), „Assessment for central heating systems with different heat sources: A case study," Energy and Buildings, 48 168-74 DOI: https://doi.org/10.1016/j. enbuild.2012.01.025

Claudy, M. C., Michelsen, C., O’Driscoll, A. (2011), "The diffusion of microgeneration technologies - assessing the influence of perceived product characteristics on home owners' willingness to pay", Energy Policy, 39 1459-69 DOI: https:// doi.org/10.1016/j.enpol.2010.12.018

Cowan, H. J. (1987), "A Note on the Roman Hypocaust, the Korean On-dol and the Chinese Kang”, Architectural Science Review, 30 4, 123-7 DOI: https://doi.org/10.1080/00038628. 1987.9696614

Day, A. R., Ratcliffe, M. S., Shepherd, K. J. (2003), Heating Systems, Plant and Control, Oxford: Blackwell DOI: https://doi. org/10.1002/9780470774458

Faiers, A., Neame, C., Cook, M. (2007), „Towards a contemporary approach for understanding consumer behaviour in the context of domestic energy use", Energy Policy, 35 4381-90 DOI: https://doi.org/10.1016/j.enpol.2007.01.003

Garvin, D. A. (1988), Managing Quality: The Strategic and Competitive Edge, New York: The Free Press

Gustavsson, L., Joelsson, A., (2007), "Energy conservation and conversion of electrical heating systems in detached houses", Energy and Building, 39 717-26 DOI: https://doi.org/10.1016/j. enbuild.2006.06.014

Hansen, D. L. (1999), Indoor Air Quality Issues, New York: Taylor \& Francis

Hart, S. J. (1989), „Product Deletion and the Effects of Strategy", European Journal of Marketing, 23 10, 6 - 17. DOI: https://doi.org/10.1108/ eum0000000000591

Kaezing J., Wüstenhagen, R., (2008), “Understanding the Green Energy Consumer", Marketing Review St. Gallen, 25 4, 12-6 DOI: https://doi. org/10.1007/s11621-008-0057-3 
Mahapatra, K., Gustavsson, L. (2008a), “An adopter-centric approach to analyze the diffusion patterns of innovative residential heating systems in Sweden", Energy Policy, 36 577-90 DOI: https://doi.org/10.1016/j.enpol.2007.10.006

Mahapatra, K., Gustavsson, L. (2008b), "Innovative approaches to domestic heating: homeowners' perception and factors influencing their choice of heating systems", International Journal of Consumer Studies, 32 75-87 DOI: https:// doi.org/10.1111/j.1470-6431.2007.00638.x

Mahapatra K., Gustavsson L. (2010), “Adoption of innovative heating systems - needs and attitudes of Swedish homeowners", Energy Efficiency, 3 1-18 DOI: https://doi.org/10.1007/ s12053-009-9057-7

Michelsen, C. C., Madlener, R., (2013), „Motivational factors influencing the homeowners' decisions between residential heating systems: An empirical analysis for Germany", Energy Policy, 57 221-33 DOI: https://doi.org/10.1016/j. enpol.2013.01.045

Munkácsi, N., Grőger, N. (2011), „A termékminőség szerepe a müszaki fogyasztási termékek vásárlási döntésében: Marketing aspektusok és kutatási kérdések." BME Tudományos Diákköri Konferencia, Budapest

Nair, G., Mahapatra, K., (2011), "Policy instruments to promote building energy efficiency from an end user point of view", ECEEE Summer Study Proceedings

Rai V., Cale Reeves D., Margolis R., (2016), “Overcoming barriers and uncertainties in the adoption of residential solar PV", Renewable Energy, 89 498-505 DOI: https://doi.org/10.1016/j. renene.2015.11.080

Rogers, E. M. (2003). Diffusion of Innovation, 5/e. Free Press, New York

Rouvinen, S., Matero, J. (2013), "Stated preferences of Finnish private homeowners for residential heating systems: A discrete choice experiment", Biomass and Bioenergy, 57, 22-32 DOI: https:// doi.org/10.1016/j.biombioe.2012.10.010

Stolyanova, E., Le Cadre, H., Osso, D., Allibe, B. (2015), "Stated Preferences for Space Heating
Investments", Economic Modelling Conference, 15-17 July 2015, Boston, United States

Strupeit, L., Palm, A., (2016), "Overcoming the barriers to renewable energy diffusion: business models for customer-sited solar photovoltaics in Japan, Germany and the United States", Journal of Cleaner Production, 123 124-36 DOI: https:// doi.org/10.1016/j.jclepro.2015.06.120

Tapaninen, A., Seppänen, M., Mäkinen, S. (2009a), "Characteristics of innovation: a customer-centric view of barriers to the adoption of a renewable energy systems", International Journal of Agile Systems and Management, 4 1/2, 98-113 DOI: https://doi.org/10.1504/ ijasm.2009.023250

Tapaninen, A., Seppänen, M., Mäkinen, S. (2009b), "Characteristics of innovation in adopting a renewable residential energy system", Journal of Systems and Information Technology, 11 4, 347-66 DOI: https:/doi. org/10.1108/13287260911002495

Vágási M. (1998), A marketing-menedzsment alapjai, Budapest: Múegyetemi Kiadó

Vágási M. (2001), Újtermék- marketing, Budapest: Nemzeti Tankönyvkiadó

Vágási M., Munkácsi N., Grőger N. (2014), „Adalékok a marketing termékklasszifikációjához: Müszaki fogyasztási termékek esete", Marketing \& Menedzsment, 48 1, 59-70

Wissner, M., (2014), "Regulation of district-heating systems", Utilities Policy, 31 63-73 DOI: https://doi.org/10.1016/j.jup.2014.09.001

Wüstenhagen R., Kaezing, J. (2010), „The Effect of Life Cycle Cost Information on Consumer Investment Decisions Regarding Eco-Innovation", Journal of Industrial Ecology, 14 1, 121-36 DOI: https://doi.org/10.1111/j.15309290.2009.00195.x 
Munkácsi Noémi, PhD hallgató

noemi.munkacsi@gmail.com

Budapesti Műszaki és Gazdaságtudományi Egyetem

Gazdaság-és Társadalomtudományi Kar

Gazdálkodás- és Szervezéstudományi Doktori Iskola

\section{Special marketing characteristics of heating products \\ Perceived quality attributes of residential heating products along the decision-making process}

\section{THE AIMS OF THE PAPER}

End customers make their investment-like purchase decisions with heating products for 15-20 years' time. The goal of the paper is to reveal the special marketing characteristics of the decision-making process by identifying the perceived quality attributes and brands at the diverse stages of the purchase process. Furthermore, the goal of the paper is to validate the results of a former research conducted with installers and service technicians about end customers' quality and brand perceptions.

\section{METHODOLOGY}

A 2-step empirical research (1. Focus group interviews, 2. Quantitative online questionnaire) was conducted with end customers in Hungary in December 2013.

\section{MOST IMPORTANT RESULTS}

End customers perceive quality attributes at the diverse stages of the purchase process analog to both industrial and residential market characteristics. End customers find price-performance ratio the deciding quality attribute by the final decision, which supports the assumption of the previous research and contradicts the opinion of service technicians about the end customers' preference.

\section{RECOMMENDATIONS}

Based on the research results, manufacturers of heating products should optimize their sales- and marketing strategy towards both installers and end customers.

Keywords: residential heat market, end customer purchase decisions, perceived quality attributes 


\title{
A magyarországi meleg férfiak ruházati márkákkal kapcsolatos attitüdjei
}

\author{
Eisingerné Balassa Boglárka - Bakó Ferenc \\ Széchenyi István Egyetem, Györ
}

\begin{abstract}
A KUTATÁS CÉLJA
Kutatásunk fókuszában a meleg férfiak állnak, valamint e célcsoport márkákkal kapcsolatos attitüdjei. E tématerület kutatását az is indokolja, hogy eddig sajnos rendkívül kevés tanulmány született e témában annak ellenére, hogy fogyasztói magatartás szempontjából egy fontos és érdekes terület. Kutatásunk célja annak vizsgálata, milyen attitűddel rendelkeznek a meleg férfiak a ruházati termékek márkáival szemben, és mindezek alapján mutatnak-e szignifikáns különbséget a heteroszexuális férfiak attitüdjeivel szemben. Ez azért is fontos, hiszen ma még viszonylag kevés, a meleg férfiakat vagy akár a teljes LMBTQ közösséget célzó marketingtevékenységet láthatunk a piacon és az ezek mögött meghúzódó gondolatmenetek sem feltétlenül alapulnak tudományos eredményeken, ismereteken.
\end{abstract}

\begin{abstract}
ALKALMAZOTT MÓDSZERTAN
A primer kutatás két lépésből állt: mélyinterjúk lefolytatásából, majd egy online kérdőíves megkérdezésből. A mélyinterjúk a hipotézisünk megalkotásában játszottak fontos szerepet. Fontosnak tartjuk megjegyezni, hogy a mélyinterjús megkérdezések során felmerültek olyan problémák, melyek indokolttá tették egy heteroszexuális férfiakból álló kontrollcsoport bevonását. A legtöbb alany azt hangsúlyozta, hogy tapasztalataik szerint a legnagyobb sztereotípia a meleg férfiakkal szemben, hogy erös feminin jellemvonásokkal rendelkeznek. Az adatgyüjtést 2017 márciusában hajtottuk végre. Összesen 328 fő került a végső mintába. A kérdőíves megkérdezés során az attitüdállítások olyan lényeges pontokra tértek ki, mint a márkák fontossága az egyén számára, márkamegítélés, márkaismertség, márkahűség, a márka és a minőség kapcsolata, márka és gazdaságosság/kockázat/tapasztalat/társadalmi megítélés kapcsolata. Az attitüdállítások összeállításánál is nagymértékben támaszkodtunk a mélyinterjúkból származó információkra. A kutatás során nem véletlen mintavételi módszert alkalmaztunk, hiszen a vizsgált sokaság tagjait előre meghatározott szervezeteken/weboldalakon keresztül kívántuk elérni és így adatokat gyüjteni.
\end{abstract}

\section{FONTOSABB EREDMÉNYEK}

A kutatás során felállított hipotézisünk az alábbi: H: a márkákkal kapcsolatos attitüdök tekintetében nincs eltérés a meleg és a heteroszexuális férfiak között. Az eredmények alapján nem találtunk szignifikáns eltérést az alminták között. A hipotézis teszteléséhez az attitüdállítások skálaértékeit használtuk fel. Eredményünk vélhetően gyakorlati jelentőséggel bír, mivel a fogyasztók, a vállalkozások, a disztribúciós csatornák és a média mind szegmentáltak, a fogyasztói magatartás sokféleségével foglalkoznak, és célzott marketingen keresztül érik el a fogyasztókat, a siker alapja azonban az adott fogyasztói szegmens tulajdonságainak pontos ismerete.

Kulcsszavak: attitüd, fogyasztói magatartás, LMBTQ, márka, marketing 


\section{BEVEZETÉS}

Az LMBTQ közösség (leszbikus, meleg, biszexuális, transznemű és queer) ${ }^{1}$ tagjait egyre több nagyvállalat szólítja meg különböző marketingkommunikációs eszközökkel, melynek központi elemét képezi az adott vállalat márkája (Banerji et al. 2012). Korábbi kutatások eredményei azonban azt mutatják, hogy számos egyén nem feltétlenül tudatos tagja a márkaközösségeknek és szubkultúráknak (Muniz \& O'guinn 2001). Kutatásunk célja annak vizsgálata, hogy milyen attitüddel rendelkeznek a meleg férfiak a ruházati termékek márkáival szemben, és mindezek alapján mutatnak-e szignifikáns különbséget a heteroszexuális férfiak attitűdjeivel szemben. Ennek vizsgálata azért is lényeges, mert a korábbi kutatások eredményeiből láttuk, hogy manapság a heteroszexuális férfiak is egyre egészségtudatosabbak, egyre inkább odafigyelnek arra, hogy ápoltak legyenek (Leitner et al. 2016). A kutatás elején a hipotézisünket is e köré a probléma köré fogalmaztuk meg:

$\mathbf{H}_{1}$ : A márkákkal kapcsolatos attitüdök tekintetében nincs eltérés a meleg és a heteroszexuális férfiak között.

A vizsgálat során először a fontosabb szakirodalmi eredményeket tekintettük át, majd egy mélyinterjú-vezérfonalat állítottunk össze, melynek segítségével hét alanyt kérdeztünk meg. Az interjúk során azonban a főbb témák érintése mellett szerettük volna, ha az alanyok kitérnek saját élettapasztalataikra is, hiszen ennek az eljárásnak a célja a probléma jobb, mélyebb megértése volt. Mivel a megkérdezett személyek sok esetben hangsúlyozták, hogy a meleg férfiakkal szemben erős sztereotípiák élnek a társadalomban, ezért indokoltnak láttuk egy heteroszexuális férfiakból álló kontrollcsoport bevonását is a vizsgálatba azzal a céllal, hogy megtudjuk, valóban kimutatható-e szignifikáns különbség a két szegmens között. A mélyinterjúk elemzése után összeállítottunk egy kérdőívet, mely több tématerületet ölelt fel. $\mathrm{Az}$ első kérdéscsoport a ruhavásárlási szokásokat érintő kérdéseket tartalmazott, a második a ruházati márkákkal kapcsolatos attitüdöket mérte fel. A harmadik rész az LMBTQ közösség médiában való szereplésével kapcsolatos kérdéseket tartalmazott, a negyedik kérdéskör pedig a társadalmi elfogadottság egyes területeit érintette. A kontrollcsoport esetében alkalmazott kérdőív értelemszerủen csak az első két kérdéskört tartalmazta, mely a vásárlási szokásokat és a márkákkal kapcsolatos attitüdöket mérte fel. A vizsgált szegmens rejtőzködő magatartása miatt célszerünek láttuk az online megkérdezési forma alkalmazását, valamint azt, hogy e kérdőívet olyan szervezeteken keresztül juttassuk el a vizsgálni kívánt célcsoporthoz, melyek nagy bizonyossággal rendelkeznek adatbázissal és elérhetőséggel az érintett személyek kapcsán.

Kérdés tehát, hogy milyen mértékben játszik központi szerepet a márka, mint érték- és társadalmi státuszkifejező szimbólum az egyes szegmensek számára, valamint, hogy milyen jelentéssel bír a márka az egyének számára.

\section{ELMÉLETI HÁTTÉR: AZ LMBTQ SZEGMENS MÉRETE A VILÁGON ÉS HAZÁNKBAN}

A Dalia Research németországi piac- és közvélemény-kutató vállalat 2016-ban egy széleskörủ kutatás keretein belül vizsgálta az LMBTQ közösséget. A kutatásban az Amerikai Egyesült Államokban és az Európai Unióban élö népességet hasonlították össze, vizsgálatuk arra irányult, hogy meghatározzák, a lakosság hány százaléka rendelkezik a heteroszexuálistól eltérő szexuális irányultsággal. Az USA-ból 1 052, az EU-ból pedig 11282 válasz érkezett. Az eredmények alapján látható, hogy az Egyesült Államokban kétszer annyian $(12,1 \%)$ vallják magukat nem heteroszexuálisnak, mint az Európai Unió tagállamaiban (5,6\%). Magyarországon ez az érték alig haladta meg az egy százalékot. A kutatásból az is kiderült, a fiatalabbak könnyebben vállalják fel irányultságukat, mint az idősebb korosztály tagjai. A heteroszexuálistól eltérő szexuális irányultság felvállalása azonban függ a társadalmi elfogadástól is, melynek értékét az első ábra szemlélteti. $\mathrm{Az}$ általunk vizsgált szegmenssel részletesen foglalkozik még Takács $(2004,2008,2011)$ és Törőcsik (2002).

1 Néhány esetben már kiegészítik e betüszót az I - interszexuális és az $\mathbf{A}$ - aszexuális kifejezésekkel is. 


\section{1. ábra: Az egyes országok kategorizációja az LMBTQ személyekhez való viszonyulás szerint}

(piros - LMBTQ elutasító; zöld - teljesen elfogadó, nyíltan „melegbarát”)

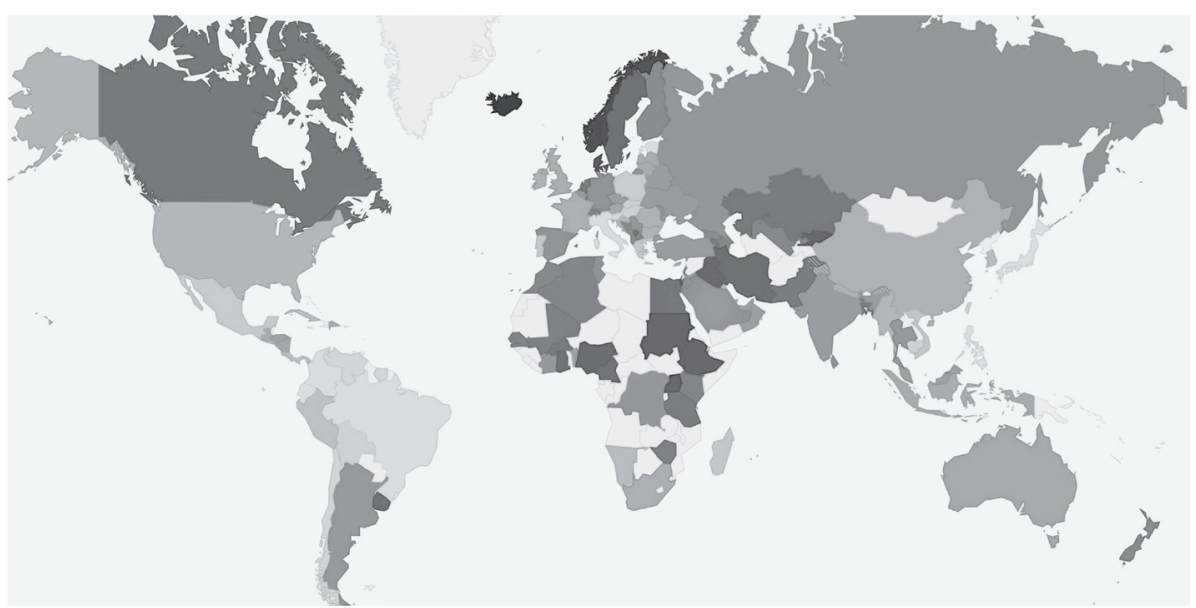

Forrás: Gay Happiness Monitor (2015)

\section{VÁLLALATOK, MELYEK MÁR MA KÜLÖN CÉLCSOPORTKÉNT TEKINTENEK AZ LMBT EMBEREKRE}

Jelenleg a piacon csupán néhány olyan nagyvállalatot találunk, amely az LMBTQ közösség tagjait is célozza marketingkommunikációs eszközökkel (Jones \& LeBlanc 2004, Peters 2011). Vállalati szempontból ez azt jelenti, hogy proaktív stratégiát folytatnak. „A szervezetek egyre tudatosabb ügyfelekkel találták magukat szemben, ami arra késztette őket, hogy proaktívan kezeljék a társadalmi érdeklődésre számot tartó ügyeket (mielőtt azok robbanással fenyegetnék a szervezetet, illetve kiváltanák különböző aktivista csoportok - környezetvédők, emberjogi csoportok, szakszervezetek - felháborodását), és így növeljék a szervezet jó hírnevét" (Konczosné 2013, 5). Így egyre többen foglalkoznak az LMBTQ ügyfelek igényeivel, egyenlő bánásmódot alkalmazva (Tuten 2005). Choong (2009) hangsúlyozza, hogy a melegek sokkal szívesebben vásárolnak azoktól a vállalatoktól, illetve olyan márkákat, amelyek valamilyen formában támogatják a közösséget. Ezeknek a termékeknek a valódi értéke az LMBTQ emberek számára nem az anyagi értékben rejlik, hanem abban a tudatban, hogy az adott szervezet melléjük áll, elfogadja és támogatja őket. Egy online felmérés alkalmával a megkérdezett LMBTQ személyek közel kétharmada azt válaszolta, hogy nagyobb eséllyel vásárol olyan vállalatoktól, melyek elfogadók és támogatják az LMBTQ embereket (Oakenfull 2013, Töröcsik 2002). Gudelanas (2011) fókuszcsoportos vizsgálat során azonosította azokat a faktorokat, melyek ,melegbaráttá” teszik az egyes vállalatokat. Ilyen tényező például a célcsoport által látogatott egyes médiumokban való hirdetés, melegek megjelenítése a „mainstream médiában", termékelhelyezés (product placement) a melegeknek szóló showmüsorokban, az LMBTQ embereknek szóló rendezvények támogatása, szponzorálása, valamint melegbarát vállalati politika, melegbarát munkahelyek teremtése.

Oakenfull (2007) és (2013) felhívja rá a figyelmet, hogy a jövőben egyre szükségesebbé válik majd, hogy a vállalatok a különböző szexuális irányultságú embereket is megcélozzák reklámjaikkal, hirdetéseikkel, hiszen piacbővítési lehetöséget kínál a vállalatoknak. Mindazonáltal fontos megjegyezni, hogy a mai napig fontos erkölcsi kérdések övezik a márkaépítési szabályokat, főleg, ha azok társadalmi felelősségvállalási kérdésköröket is érintenek (Bennett \& Lagos 2007). A fogyasztók a márkákkal szemben sokszor saját jelentéseket generálnak, nem pedig azokkal azonosulnak, melyeket a vállalat előre megtervezett (Schulman 1998; Kozinets 2001; Baxter 2010; Tharp 2001) 


\section{KUTATÁSMÓDSZERTAN}

Az adatgyüjtést 2017 márciusában hajtottuk végre. A kutatásban összesen 420 meleg férfi vett részt, melyből 328 fö került a végső mintába. A nagymértékủ elemszám csökkenés azzal magyarázható, hogy a kutatásba csupán a 21 és 50 év közötti személyek kerültek, valamint a sok válaszmegtagadást tartalmazó kérdoíveket is kizártuk a vizsgálatból. A megkérdezés online kérdőíves módszerrel történt, mivel a vizsgált célcsoport ezzel a módszerrel volt a legkönnyebben elérhetö. A kérdőívet több szervezethez is eljuttattuk, melyek az alábbiak: Planet Romeo Magyarország, HuMen magazin, Háttér Társaság, Gay Point társkereső. A szervezetek megkeresését az indokolta, hogy általuk tudtuk a leggyorsabban elérni a vizsgálandó célcsoportot, mivel egy rejtőzködő szegmensről beszélünk. A kérdőív, melyet elküldtünk a szervezetek számára, több kérdéscsoportot is tartalmazott. Első részében a ruházati termékek vásárlásával kapcsolatos kérdéseket sorakoztattunk fel, olyan területeket érintve, mint a vásárlások gyakorisága, helye, valamint a legfontosabb szempontok a vásárlási döntés meghozatalakor. A második szakaszban a válaszadóknak márkákkal kapcsolatos attitüdállításokat kellett értékelniük egy négyfokozatú skála segítségével. A skála két végpontja a „teljesen egyetértek” és az „egyáltalán nem értek egyet” válaszlehetőség volt. Mivel a skálának nem volt természetes középpontja, ezért különálló lehetőségként a „nem tudom, nem válaszolok" lehetőséget is megadtuk annak esetére, ha a válaszadó nem tud dönteni a két végpont között. A harmadik rész az LMBTQ közösség médiában való szereplésével, a negyedik pedig társadalmi elfogadottságukkal kapcsolatos kérdéseket tartalmazott. Ebben a cikkünkben a márkákkal kapcsolatos kérdésköröket tárgyaljuk meg. A megkérdezés során az attitűdállítások olyan lényeges pontokra tértek ki, mint a márkák fontossága az egyén számára, márkamegitélés, márkaismertség, márkahüség, a márka és a minöség kapcsolata, márka és gazdaságosság/kockázat/tapasztalat/társadalmi megítélés kapcsolata. Az attitüdállítások összeállításánál is nagymértékben támaszkodtunk a mélyinterjúkból származó információkra. A kutatás során nem véletlen mintavételi módszert alkalmaztunk, hiszen a vizsgált sokaság tagjait elöre meghatározott szervezeteken/weboldalakon keresztül kívántuk elérni és így adatokat gyüjteni. A minta természetesen így nem reprezentatív a teljes sokaságra nézve (Malhotra 2005).

\section{A mélyinterjúk föbb eredményei}

Összesen hét személlyel készítettünk interjút. $\mathrm{Az}$ interjúalanyok átlagéletkora 27 év volt, többségük már a munka világában tevékenykedik, kettő egyetemi hallgató volt, egy pedig levelező tagozaton tanul, mellette, fóállásban dolgozik. Igyekeztünk a beszélgetést úgy irányítani, hogy a lényeges pontok mellett az interjúalanyok a saját fontosnak vélt tapasztalataikat, véleményüket is elmondhassák a beszélgetés során.

$\mathrm{Az}$ interjúalanyok egyöntetủen leginkább azt hangsúlyozták, hogy az „átlagos” meleg férfiak szinte semmiben sem különböznek a heteroszexuális férfiaktól, a szexuális irányultságukat kivéve. Elmondásuk szerint ez az egyik legnagyobb sztereotípia, hogy a meleg férfiak erősen nőies vonásokkal rendelkeznek, a megkérdezettek szerint ez egyáltalán nem igaz. Az effajta viselkedés nem tartozik hozzá a homoszexualitáshoz. Ezzel együtt a megkérdezett személyek azt is állították, hogy e problémának a gyökere abból ered, hogy bár az emberek lényegesen több ,átlagos” meleg férfival találkoznak, mint kirívó példával, erről mit sem tudnak, hiszen róluk nem is sejtik, hogy valójában melegek. Fogalmuk sincs arról, ami a valóság, hogy a meleg férfiak pontosan ugyanúgy néznek ki, ugyanúgy viselkednek, ugyanúgy tanulnak, dolgoznak, számlákat fizetnek, mint a heteroszexuális férfiak. Tehát, mivel az emberek csak a kirívó eseteket látják, ezt általánosítják minden meleg férfira. Azt is hangsúlyozták, hogy a média is erősen hozzájárul e sztereotípiák kialakulásához és megerősítéséhez. Interjúalanyaink egyike sem tartotta megalapozottnak azt a vélekedést, miszerint a meleg férfiak sokkal többet látogatnák a ruhaboltokat vagy lényegesen márkacentrikusabbak lennének heteroszexuális embertársaiknál. Elmondásuk szerint ez is éppúgy változó, mint ahogy vannak, akik az elektrotechnika iránt érdeklődnek, míg mások az irodalom, a mủvészet, a természettudományok vagy épp a divat iránt. Ez nem irányultság kérdése, legalábbis nem a szexuális irányultságé.

$\mathrm{Az}$ interjúk során számtalanszor elhangzott, hogy alanyaink úgy vélik, a társadalomban az a sztereotípia él a meleg férfiakról, hogy erősen feminin jellemvonásokkal rendelkeznek, márkaés divatcentrikusak, ezért indokoltnak láttuk egy heteroszexuális férfiakból álló kontrollcsoport bevonását a kutatásba, ennek az állításnak a vizsgálatára, ezért hipotézisünket is e probléma köré fogalmaztuk meg. 


\section{KUTATÁSI EREDMÉNYEK}

A meleg férfiak megkérdezésével párhuzamosan tehát egy másik felmérést is végeztünk, melynek célcsoportja a heteroszexuális férfiak voltak. A kontrollcsoport alkalmazását a mélyinterjúk során a válaszadók által gyakran említett sztereotípiák alapjainak vizsgálata és egyéb magatartásbeli, illetve attitüdbeli különbségek vizsgálata miatt láttuk szükségesnek. A kérdések teljes mértékben megegyeztek a meleg férfiak esetében használt kérdésekkel. Az ebből kialakított minta életkor és lakhely szerinti megoszlásokat tekintve azonos a meleg férfiakból álló mintán belüli megoszlásokkal. A heteroszexuális férfiakból álló mintát kontrollcsoportként használtuk annak vizsgálatához, hogy a meleg férfiak és a heteroszexuális férfiak márkákkal kapcsolatos attitüdjei tekintetében található-e szignifikáns különbség az alminták között. A kutatás folyamatát a 2. ábra mutatja be.

\section{2. ábra: Kutatási folyamatábra}

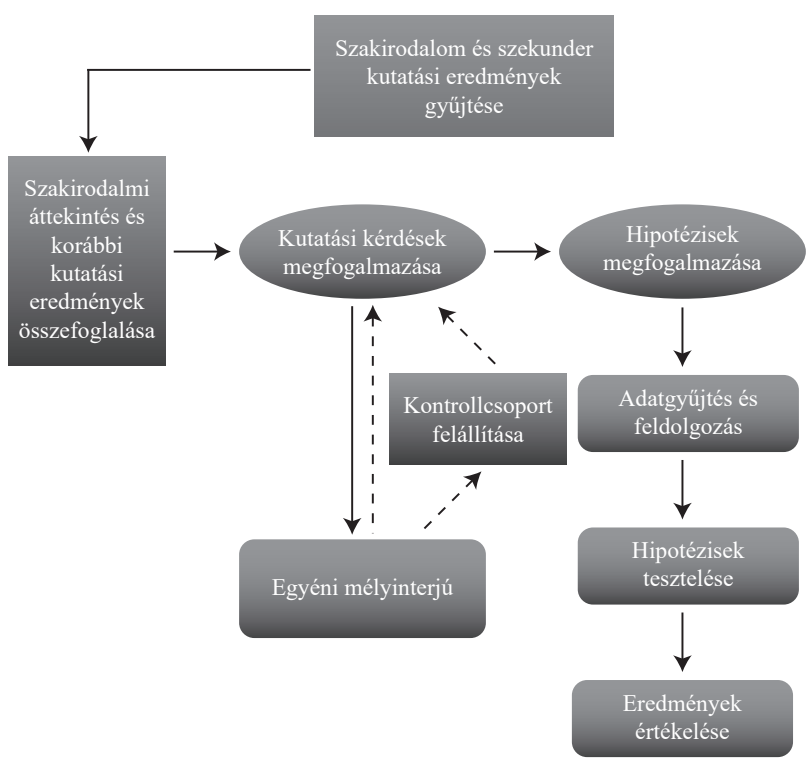

Forrás: saját szerkesztés

A meleg férfiakból álló minta föbb demográfiai jellemzői az alábbiak: a válaszadók közül a 21 és 50 év közötti egyének kerültek a mintába. A mintán belüli átlagéletkor 30 év, 7,26 év szórással. A megkérdezettek 58,8\%-a 21-30; 29,3\%-a 31-40 és 11,9\%-a 41-50 év közötti személy. Ami a lakhelyet illeti, a válaszadók több mint fele $(57 \%)$ a fövárosban él. 35,4\%-uk városi lakhellyel rendelkezik, ezen belül $19,5 \%$ a megyei jogú városban, $15,9 \%$ a városban élök aránya. A megkérdezettek mindössze 7,6\%-a él községben. Az iskolai végzettség szerinti megoszlás teljes mértékben a korábbi kutatások és szakirodalmak eredményeit támasztja alá, miszerint az LMBTQ társadalom tagjainak többsége magas iskolai végzettséggel rendelkezik (Takács 2011). A mintában szereplő válaszadók döntő többsége (47\%) föiskolai vagy egyetemi diplomát tudhat magáénak. Szakközépiskolai/gimnáziumi végzettséggel a megkérdezettek 43\%-a rendelkezik, 5,8\% szakmunkásképzőt, 2,1\% csupán általános iskolai végzettséggel rendelkezik. A jövedelem kategorizálásához az alábbi csoportosítást alkalmaztuk:

- Alacsony (70 ezer Ft alatt)

- Átlagos (70-130 ezer Ft)

- Átlag feletti (131-250 ezer Ft)

- Kifejezetten magas (251 ezer Ft felett) (Bakó 2015). 
A mintáról az összesített eredmények alapján megállapítható, hogy a megkérdezettek többsége átlag feletti jövedelemmel rendelkezik. A válaszadók 25,3\%-a kifejezetten magas, míg 39,6\%-uk átlag feletti fizetést tudhat magáénak. 18,3\%-uk átlagos fizetésről számolt be, alacsony jövedelemből pedig a mintában szereplő egyének 7,9\%-a gazdálkodik. A válaszadók 8,8\%-a nem rendelkezik jövedelemmel. A jövedelemmel nem rendelkező válasz- adók 70\%-a még tanulmányokat folytat.

A megkérdezés során a válaszadóknak különböző márkákkal kapcsolatos állításokat kellett értékelniük. Az attitűdállítások kidolgozásánál nagymértékben támaszkodtunk Veres (2010) életstílus alapú fogyasztói szegmensekkel kapcsolatos korábbi tanulmányára. Az eredményeket az alábbi 1. táblázatban foglaljuk össze.

\section{1. táblázat: A márkákkal kapcsolatos attitűdállítások sorrendje - az egyes skálaértékek alapján}

\begin{tabular}{|c|c|c|}
\hline & Meleg férfi & Hetero férfi \\
\hline & Átlag & Átlag \\
\hline Márkaválasztás során a saját tapasztalataim a mérvadók. & 3,46 & 3,27 \\
\hline $\begin{array}{l}\text { Vannak olyan ruházati márkák, amelyek jobban illenek } \\
\text { hozzám, míg mások kevésbé. }\end{array}$ & 3,18 & 3,24 \\
\hline $\begin{array}{l}\text { A márkahűség ugyan meggyorsítja a választást, de számos jó } \\
\text { lehetőséget mulaszt el az, aki nem hajlandó kísérletezni. }\end{array}$ & 2,95 & 3,48 \\
\hline Általában nem ragaszkodom egy márkához. & 2,93 & 2,80 \\
\hline $\begin{array}{l}\text { Könnyebben váltok márkát az alacsonyabb árkategóriájú } \\
\text { termékeknél. }\end{array}$ & 2,85 & 2,96 \\
\hline $\begin{array}{l}\text { Azok a ruházati termékek, amelyeket otthon használok, nem } \\
\text { márkásak. }\end{array}$ & 2,69 & 2,71 \\
\hline Vannak olyan ruházati márkák, amelyek jellemeznek engem. & 2,64 & 2,32 \\
\hline $\begin{array}{l}\text { Ugy gondolom, márkás termékeket vásárolni gazdaságosabb, } \\
\text { mert bár drágább, minőségével visszahozza az árát. }\end{array}$ & 2,61 & 2,45 \\
\hline $\begin{array}{l}\text { Az ismert márkák vásárlása megkönnyíti a vásárlást, hiszen } \\
\text { pontosan tudom, mit keressek. }\end{array}$ & 2,60 & 2,53 \\
\hline $\begin{array}{l}\text { Az ismert márkák vásárlása kevésbé kockázatos, hiszen } \\
\text { mindig az elvárt minőséget kapom. }\end{array}$ & 2,55 & 2,56 \\
\hline Általában márkás ruhákat hordok. & 2,54 & 2,48 \\
\hline Általában nem foglalkozom a márkákkal. & 2,51 & 2,47 \\
\hline Gyakran próbálok ki új márkákat. & 2,48 & 2,53 \\
\hline $\begin{array}{l}\text { Sokat elárul egy emberröl, hogy milyen márkájú ruhákat } \\
\text { visel. }\end{array}$ & 2,37 & 2,12 \\
\hline $\begin{array}{l}\text { Bolti vásárlás előtt gyakran megnézem az adott márka } \\
\text { webshopjában lévő termékkínálatot. }\end{array}$ & 2,29 & 2,23 \\
\hline A márka a minőség jelzője. & 2,27 & 2,21 \\
\hline Ismeretlen márkájú termékeket nem szoktam vásárolni. & 2,20 & 2,04 \\
\hline $\begin{array}{l}\text { Olyan márkákhoz vagyok hü, amelyek kifejezik a társadalmi } \\
\text { státuszomat. }\end{array}$ & 2,20 & 1,91 \\
\hline Egy termék minőségét a márkája alapján döntöm el. & 2,09 & 1,95 \\
\hline $\begin{array}{l}\text { Olyan márkákat választok, amelyeket a hozzám közelálló } \\
\text { ismeröseim is kedvelnek. }\end{array}$ & 1,81 & 1,68 \\
\hline
\end{tabular}

Forrás: saját szerkesztés 
Az eredmények alapján elmondhatjuk, hogy márkaválasztás során a meleg férfiak számára leginkább saját tapasztalataik a mérvadók. Bár a márkahüségről úgy vélekednek, hogy az meggyorsítja a vásárlási folyamatot, ennek ellenére nem feltétlenül márkahüek, hiszen ez ahhoz vezetne, hogy egy esetleges jobb ajánlatról lemaradhatnak. Alacsonyabb árú termékek esetében még kevésbé márkahúek, ámbár úgy vélekednek, hogy a márkás termékek ugyan drágábbak, de a magasabb minőség kompenzálja mindezt. Azok az attitüdállítások pedig, melyek szerint a márka a minőség jelzője, kifejezheti az egyén társadalmi helyzetét, lényegesen negatívabb értékeket kaptak.

Amennyiben a meleg férfiak által adott válaszok átlagértékeket összehasonlítjuk a heteroszexuális férfiak értékeivel, láthatjuk, hogy szinte alig találunk lényegesebb eltéréseket. Hipotézisünk is a két szegmens közti különbségvizsgálatára irányul.

\section{A HIPOTÉZISVIZSGÁLAT FÖBB EREDMÉNYEINEK ÖSSZEFOGLALÁSA}

A kutatás során felállított hipotézisünk az alábbi volt: H: A márkákkal kapcsolatos attitüdök tekintetében nincs eltérés a meleg és a heteroszexuális férfiak között.

A hipotézis teszteléséhez a korábban már bemutatott attitüdállításokat használtuk fel. A kérdőívben szereplő attitűdállítások közül mindössze három esetben lehetett különbséget kimutatni a két alminta között, melyek az alábbiak:

1. Márkaválasztás során a saját tapasztalataim a mérvadók.

2. A márkahüség ugyan meggyorsítja a választást, de számos jó lehetőséget mulaszt el az, aki nem hajlandó kísérletezni.

3. Ismeretlen márkájú termékeket nem szoktam vásárolni.

Az eltérések mértéke azonban e három esetben is rendkívül kismértékü, csupán néhány tized értékü. Bár a varianciára tett hipotézisvizsgálat alternatív hipotézise $\left(H_{l}\right)$ úgy szól, hogy legalább két átlagérték szignifikánsan különbözik (Sajtos Mitev 2007), jelen esetben három érték különbözik szignifikánsan a többitő̉l, azonban arányaiban ez is csekély jelentőségú. Az eredmények alapján tehát kijelenthetjük, a márkákkal kapcsolatos attitüdök tekintetében nincs szignifikáns eltérés a meleg és a heteroszexuális férfiak között (Bakó 2017).

\section{ÖSSZEFOGLALÁS}

Kutatási eredményeink alapján megállapíthatjuk, hogy a meleg férfiak ruházati márkákkal kapcsolatos attitüdjei szignifikánsan nem térnek el a heteroszexuális férfi vásárlókétól. Ennek vizsgálata azért vált fontossá, mert a mélyinterjúk lefolytatása során a megkérdezettek kiemelték, a társadalomban nagyon erősen él az a sztereotípia, hogy a meleg férfiak erős nőies vonásokkal bírnak, amit az előzőekben tárgyalt kutatási eredmények azonban cáfolnak. Láthattuk, hogy a ruházati termékek márkáival kapcsolatos attitüdök tekintetében nem található szignifikáns eltérés a vizsgált szegmensek között, ennek tekintetében tehát a meleg férfiaknak szóló reklámkampányokban nem a megkülönböztetésre kell helyezni a hangsúlyt. Épp ellenkezőleg, a szegmens elfogadására, teljes értékü társadalmi csoportként kell gondolni, hiszen ez segíthet abban, hogy az adott vállalat termékeivel, márkáival szemben idővel lojálissá váljanak. Ezek a megállapítások gyakorlati jelentőséggel bírnak, mivel a fogyasztók, a vállalkozások, a disztribúciós csatornák és a média mind szegmentáltak, az emberi hozzáállás és a viselkedés sokféleségével foglalkoznak, és célzott marketingen keresztül érik el a fogyasztókat, a siker alapja azonban az adott fogyasztói szegmens tulajdonságainak pontos ismerete. Az eredményekböl arra is következtethetünk, hogy a heteroszexuálistól eltérő szexuális irányultságú emberek esetében nem feltétlenül rajzolódik ki egy, a szokásostól eltérő életstílus vagy magatartásbeli mintázat. Mindezek bizonyítására azonban még további kutatások szükségesek. Bár kutatásunk egy konkrét területet érintett, azonban helyenként próbált szélesebb körben kitekinteni, hogy esetlegesen iránymutatást adjon a kutatók számára további kutatási irányok meghatározásához.

Emellett bízunk benne, hogy kutatásunk hozzájárul a magyarországi LMBTQ közösség tagjainak jobb megértéséhez és elfogadásához, hiszen egy társadalmi szempontból is fontos és értékes csoportról van szó. A békés együttélés, a megfelelő életkörülmények kialakítása, az egymás iránti tisztelet és elfogadás mind-mind alapvető feltételei a kiegyensúlyozott, boldog életnek. Reményeink szerint tanulmányunk ösztönzi majd a tudomány területén tevékenykedőket, hogy további szempontok alapján vizsgálják meg részletesen az LMBTQ közösséget és segítsenek a jelenleg is élő sztereotípiák eloszlatásában. 


\section{HIVATKOZÁSOK}

Bakó F. (2015), Bolt volt, bolt nem volt - A vasárnapi zárva tartás hatása a fogyasztói magatartás tükrében, Széchenyi István Egyetem

Bakó F. (2017), Ahol a szivárvány véget ér - Meleg férfiak, mint egy máig érintetlen fogyasztói szegmens Magyarországon, Széchenyi István Egyetem

Banerji, A., Burns, K., Vernon, K. (2012), „Creating Inclusive Workplaces for LGBT Employees in India”, Hong Kong: Community Business, 12

Baxter S. (2010), „Evidence on the Marketing Approaches Targeting Gay and Lesbian Consumers," Global Journal of Business Research, 4 2, 125-39

Bennett, W. L., Lagos, T. (2007), „Logo logic: The ups and downs of branded political communication", The Annals of the American Academy of Political and Social Science, 611 1, 193-206 DOI: https://doi.org/10.1177/0002716206298484

Choong, K. (2009), ,Supporting the Brand Community: Buying Gay", University of the Sunshine Coast

Gay Happiness Monitor (2015), https://www.planetromeo.com/wp-content/uploads/2015/05/ GAY HAPPINESS MONITOR 2015.pdf (letöltve 2017.06.02.)

Gudelanas, D. (2011), „Consumer Myths and the Gay Men and Women Who Believe Them: A Qualitative Look at Movements and Markets", Psychology and Marketing, 28 1, 53-68 DOI: https://doi.org/10.1002/mar.20380

Jones, R., LeBlanc, R. (2004), „Sport, sexuality and representation in advertising: The political economy of the pink dollar", In: Sport, culture and advertising, Routledge, 131-47 DOI: https://doi.org/10.4324/9780203462003_chapter_6

Konczosné Szombathelyi. M. (2013), „A hírnév és menedzselése", In: Tompos A. - Ablonczyné Mihályka L. (szerk.): „Növekedés és egyensúly" Kautz Gyula Emlékkonferencia elektronikus kötete; 1-11 http://kgk.sze.hu/ images/dokumentumok/kautzkiadvany2013/ marketing/kszm.pdf

Kozinets, R. V. (2001), „Utopian enterprise: Articulating the meanings of Star Trek's culture of consumption," Journal of Consumer Research, 28 1, 67-88 DOI: https://doi.org/10.1086/321948

Leitner, G., Rust, P., Elmadfa, I. (2016), „Men’s health eating habits. Health status and health behaviour of young Austrian men aged 17 to 20 years in context to their lifestyles," Aktuelle
Ernährungsmedizin, 4103 DOI: https://doi. org/10.1055/s-0036-1583904

Muniz, A. M., O’guinn, T. C. (2001), „Brand community," Journal of Consumer Research, 27 4, 412-32

Naresh K. Malhotra (2005): Marketingkutatás. Akadémiai Kiadó, Budapest

Oakenfull G. W. (2007), „Effects of Gay Identity, Gender and Explicitness of Advertising Imagery on Gay Responses to Advertising," Journal of Homosexuality, 53 4, 49-69 DOI: https:/doi. org/10.1080/00918360802101278

Oakenfull G. W. (2013), „What Matters: Factors Influencing Gay Consumers' Evaluations of 'Gay-Friendly' Corporate Activities", Journal of Public Policy \& Marketing, 32 special issue, 79-89 DOI: https://doi.org/10.1509/ jppm.12.050

Peters, W. (2011), „Pink dollars, white collars: Queer as Folk, valuable viewers, and the price of gay TV", Critical Studies in Media Communication, 28 3, 193-212 DOI: https://doi.org/10. 1080/15295036.2011.559478

Sajtos L. - Mitev A. (2007): SPSS kutatási és adatelemzési kézikönyv, Alinea kiadó

Schulman S. (1998), The Harvard Gay \& Lesbian Review; Boston5.1, Jan 31, 1998, 17

Takács J. (2004), Homoszexualitás és társadalom, ÚMK

Takács J. (2011), A homofóbia Magyarországon, L'Harmattan Kiadó

Takács J. - Mocsonaki L. - P. Tóth T. (2008), „A leszbikus, meleg, biszexuális és transznemü (LMBT) emberek társadalmi kirekesztettsége Magyarországon", Esély, 3

Tharp, M. C. (2001), Marketing and consumer identity in multicultural America. Sage Publications

Törőcsik M. (2002), „A 'meleg' fogyasztó célcsoport vagy 'kis színes"', Marketing \& Management, 36 4, 57-60

Tuten, T. L. (2005), „The effect of gay-friendly and non-gay-friendly cues on brand attitudes: A comparison of heterosexual and gay/lesbian reactions", Journal of Marketing Management, 21 3-4, 441-61 DOI: https://doi. org/10.1362/0267257053779073

Veres Z. (2010): Életstílus alapú fogyasztói szegmensek Magyarországon, Szegedi Tudományegyetem, Gazdaságtudományi Kar, Üzleti Tudományok Intézete, Szeged 
Bakó Ferenc PhD hallgató bako.ferenc@sze.hu Széchenyi István Egyetem, Györ

\section{The attitudes of hungarian homosexual men towards clothing brands}

\section{THE AIMS OF THE PAPER}

Our research focuses on homosexual men as well as on this target group's attitude towards brands. The research into this topic is justified by the extremely low number of publications about the topic, in spite of that this is an important and interesting field from the viewpoint of consumer behaviour. The aim of our research is to analyse what attitudes homosexual men have towards clothing brands and whether their attitudes significantly differ, based on these, from those of heterosexual men. It is important because there have been a relatively few marketing activities targeting either homosexual men or the whole LMBTQ community in the market, and the thoughts behind them are not necessarily based on scientific results or knowledge.

\section{METHODOLOGY}

Primary research consisted of two steps: conducting in-depth interviews, then an online questionnaire survey. In-depth interviews had an important role in developing our hypothesis. It is important to note that during in-depth interviews such problems had arisen which made the involvement of a control group consisting of heterosexual men necessary. Most interviewees stressed that according to their experiences the main stereotype about homosexual men is that they have strong feminine features. Data were collected in March 2017. A total of 328 people were in the final sample. In case of the questionnaire survey attitude statements dealt with the importance of brands for the individual, brand assessment, brand awareness, brand loyalty, the relationship between brand and quality, and the relationship between brand and thrift/risk/experience/social assessment. When compiling attitude statements, we depended upon information deriving from in-depth interviews to a great extent. In case of the research we did not apply simple random sampling since we wanted to reach the analysed population's members through predefined organisations/websites, and we wanted to collect data this way.

\section{MOST IMPORTANT RESULTS}

Our research hypothesis is as follows: $\mathrm{H}$ : there is no difference between homosexual and heterosexual men regarding the attitudes towards brands. Based on the findings we did not find significant difference between the subsamples. To test the hypothesis, we used the scale values of attitude statements. Our findings are presumably of practical importance as consumers, enterprises, distribution channels and media are all segmented, they deal with the diversity of consumer behaviour, and reach the consumers through targeted marketing, however, the basis of success is the precise knowledge about the features of the given consumer segment.

Keywords: attitude, consumer behaviour, LMBTQ, brand, marketing 



\title{
Felhasználóközpontú szempontok különböző módú megjelenése a szoftverfejlesztésben - Kvalitatív kutatás a hazai cégek gyakorlatáról
}

\author{
Szabó Bálint \\ Budapesti Műszaki és Gazdaságtudományi Egyetem
}

\begin{abstract}
A TANULMÁNY CÉLJA
A kutatás célja a különböző típusú szoftvertermékek elő́llítási folyamatának megismerése abból a szempontból, hogy abban a gyakorlatban a felhasználóközpontú szempontok hogyan jelennek meg. A kutatás tehát a szoftverfejlesztés modelljeinek gyakorlati megvalósításaiban kívánja megtalálni a használhatóság és a felhasználói élmény (User eXperience) szempontjainak és módszereinek szerves helyét.
\end{abstract}

\begin{abstract}
ALKALMAZOTT MÓDSZERTAN
A szoftvercégek jelenlegi gyakorlata interjúsorozat segítségével tárható fel alaposan. Egy megfelelően változatos 15-20 fős, szakmai vezetőkből álló mintán elvégzett kutatás segítségével a cégek gyakorlata és a válaszadók témával kapcsolatos gondolkodásmódja megismerhető. Jelen cikk ennek a nagyobb kutatásnak a kutatási kérdéseit és előzetes eredményeit mutatja be öt igen különböző interjú kvalitatív összegzésének a segítségével.
\end{abstract}

\section{LEGFONTOSABB EREDMÉNYEK}

Az elözetes eredmények jól szemléltetik, hogy a szoftverfejlesztési folyamatokban eltérések vannak. Azok eltérö lépések mentén, különböző eszközök alkalmazásával valósulnak meg, így a felhasználók bevonása is eltérő pontokon, más-más módszerek alkalmazásával történik. A fejlesztések a legtöbb esetben agilis módon történnek, de ennek ellenére azokban a vártnál kevesebb a visszacsatolás. Ugyan a vállalatok jelentős részénél már agilis fejlesztés zajlik, de úgy tűnik, hogy nem ez a tényező határozza meg a szervezetek UX-es érettségét. A UX érettség magasabb azoknál a vállalatoknál, ahol a felhasználóközpontú megközelítéssel foglalkozó csapatok tevékenységeke a szervezet egészére kiterjed. A kapott eredmények alapján továbbá elmondható az is, hogy az empirikus módszereket alkalmazó közép- és nagyvállalatok a méretüktöl függetlenül tudatosabban és sikeresebben implementálták a UX-es folyamatokat. Az eredmények alapján elmondható az is, hogy a szervezeti méret, illetve a vállalati besorolás alapján az 50 fö alatt kisvállalatok azok, amelyek a felhasználóközpontú megközelítések implementálását bizonyos korlátok mellett tudják csak alkalmazni.

\section{ÚJDONSÁGOK}

A különböző UX-es gyakorlatoknak az áttekintése és szintézise a különböző cégek jövendőbeli döntéshozói számára is hasznosak, illetve a szoftverpiacon alkalmazott módszertanok rendszerezett áttekintése tudományos szempontból is újszerü.

Kulcsszavak: felhasználói élmény, emberi tényezök, szoftverfejlesztés, UX érettség 


\section{BEVEZETÉS}

A szoftvertermékek szüken értelmezett előállítási folyamata során a cégek gyakorlatában általában több, nagy hagyománnyal rendelkező, részben szabványosított, egymással rivalizáló modell jelenik meg. Ezek a fejlesztési modellek tipikusan programozáscentrikusak, így azok nehezen illeszkednek a tágabban értelmezett termékmenedzsment folyamatok modelljeibe, valamint alapvetö problémaként azonosítható a felhasználóközpontúság hiánya is.

A technológia fejlődésével átalakuló modern minőségmenedzsment folyamatközpontúvá vált. A folyamatmenedzsment, a folyamatok optimalizálása minden szektorban elengedhetetlen, de különös mértékben érinti a gyorsan változó szoftverpiaci termékeket és fejlesztési folyamatokat (Lee \& Chang 2006). Kulcskérdés a folyamatok folyamatos javítása, mint a TQM vezetési filozófia egyik alapelve (Tenner \& DeToro 1992).

Ennek köszönhetően a szoftverfejlesztési folyamatok állandóan változnak, ami hatással van az implementált felhasználóközpontú szempontok és alkalmazott módszerek alkalmazkodóképességére is.

Az ember-számítógép interakció tudományterületének fejlődése következtében mára a felhasználóközpontú tervezési technikák széles tárháza áll rendelkezésre, hogy az elóállított szoftvertermékek megfelelő felhasználói élményt nyújtsanak (Sikorski 2012). A probléma azonban, ami már jó ideje fennáll, hogy ennek az elismerésnek a fontossága még nem mindenhol jelenik meg a szoftverfejlesztés módszereiben (Seffah et al. 2005, Capretz 2014, Lenberg et al. 2015).

A különféle szoftvertermékek előállítása során az eltérő méretü és profilú cégek más és más szoftverfejlesztési módszertanokat követnek, amelyek befolyásolják a felhasználóközpontú megközelítések integrálhatóságát és annak mértékét, így a kutatás szempontjából alapvető kifejezések is mást jelentenek a szervezetek szereplöi számára.

Ilyen kifejezés például az ISO 9241-210:2010 szabványban is előforduló használhatóság (Hercegfi 2005, Rubin et al. 2008), vagy a manapság gyakran a siker kulcsaként azonosított felhasználói élmény (Sharp et al. 2007) fogalma.

A felhasználói élmény (User eXperience) azon benyomások, érzések összességét takarja, ami a felhasználóban keletkezik egy termék (például szoftver) használata közben. A meghatározásával számos tudományos publikáció foglalkozik, boncolgatva a kifejezés pontos jelentését (Hassenzahl \& Tractinsky 2006, Law et al. 2009).
A vállalati UX-es gyakorlatoknak az áttekintése és szintézise a különböző (nem csak szoftveres) cégek jövendőbeli döntéshozói számára is hasznosak, illetve a szoftverpiacon alkalmazott módszertanok rendszerezett áttekintése tudományos szempontból is újszerü.

\section{A SZOFTVERFEJLESZTÉSI MODELLEK FEJLŐDÉSE}

A szoftvertermékek fejlesztése során alkalmazott aktuális trendek különböző utakat jártak be a közelmúltban, amelyek alapvetően határozzák meg a felhasználóközpontú szempontok és a kapcsolódó módszertanok alkalmazhatóságát. A gyakorlatban igen sokféle, idealizált, hagyományosnak tekinthető szoftverfejlesztési modell érhető el a különféle vállalatok számára, amelyek Mohapatra (2009) értelmezése szerint négy alapkategóriába sorolhatók be: ezek a kódolás és javítás, a vízesés, az evolúciós és spriál típusú modellváltozatok.

A kezdetekben a szoftveres projektek során a követelmények minden esetben ismertek voltak, így a tényleges fejlesztési folyamat csak kódolási és javitási tevékenységekből állt. Az idő múlásával azonban ez a „modell” már egyáltalán nem bizonyult alkalmazhatónak, hiszen az informatika térnyerésével együtt a fejlesztési környezetek is dinamikusan változtak, ami miatt a szoftvertermékek előállítása szisztematikusabb módszert igényelt.

A SAGA légvédelmi szoftverprojekt hatására Benington (1983), Rosove (1967) és Royce (1970) megalkotta a szoftverfejlesztési folyamatok vízesés modelljét. Ebben a modellben a fejlesztési szakaszok lépcsőzetesen kapcsolódtak egymáshoz, ahol a következö lépés csak akkor vehette kezdetét, amikor az előző lezárult (Birell-Ould, 1988). Ez a fejlesztési megoldás volt akkoriban a legtöbb szoftverbeszerzési eljárás alapja, idővel azonban kiderült a módszer legnagyobb hátránya: a szinte minden fázisban megjelenő részletes dokumentáció, mint sikerkritérium elvárás - főleg a követelmények meghatározása és a rendszertervezés tekintetében (Boehm 1988).

Ezért a későbbiekben megjelenő evolúciós modell már lehetővé tette a különböző fejlesztési tevékenységek egyidejű végzését. A gyors visszacsatolás és a megfelelő funkcionalitású rendszer létrehozása érdekében a modell a folyamatosan müködő (vevőnek bemutatható) szoftvertermék elóállítására koncentrált (Denning et al. 2008). Ezeket az alapokat használta fel a későbbiekben az inkrementális, illetve a prototípus-központú fejlesztési megközelítés is. 
A spirál modell a szoftverek fejlesztési folyamatára spirál formában tekintett, így a lépéseket egymást nem követő tevékenységek sorozataként kezelte. A szoftverfejlesztési modellek között ez volt az első olyan, amely nagyobb hangsúlyt helyezett a kockázatelemzésre (Munassar \& Govardhan 2010).

$\mathrm{Az}$ elmúlt évtizedekben ezekre a modellekre építve igen sokféle, hagyományosnak már kevésbé tekinthető szoftverfejlesztési megközelítés alakult ki - például a komponens alapú fejlesztés (Gorton et al. 2006), a win-win spiral változat (Boehm et al. 1998), vagy a RUP folyamatmodell (Kruchten 2000). Ezek mind iteratív és inkrementális megoldások, amelyek középpontjában már a változó megrendelői követelményeknek való megfelelés áll.

Manapság a leginkább elterjedt fejlesztési módszer az agilis, amelynek a legfontosabb elemeit az Agilis kiáltvány tartalmazza, amit az irányzat követei fogalmaztak meg (Fowler \& Highsmith 2001) a 2000-es években. Az agilis együttmüködésre építő, folyamatosan fejlődő, minőségfókuszú fejlesztési megközelítés, amelynek a gyökerei a Lean menedzsment és a Kaizen módszer elemeire vezethetők vissza (Dingsøyr et al, 2012). A korábbi modellekkel ellentétben ez a módszertan és az abban használt eszközök már sokkal inkább koncentrálnak a piaci változásokra és a vevőkkel való folyamatos kommunikációra, előtérbe helyezve a felmerülő igényekkel kapcsolatos visszajelzések rugalmas menedzselését (Mohapatra 2009).

Ez a módszertan tehát igen gyorsan teszi lehetővé a felmerülő változások menedzselését a termékfejlesztés irányába. Ezeknek a rövidtávon bekövetkező változásoknak a megvalósítása rugalmas hozzáállást igényel, amelyet a szervezetek érték-alapú gondolkodással tudnak megvalósítani, a korábbi terv-alapú megközelítés helyett. A gyakorlatban éppen ezért az agilis módszertanokat gyakran kombinálják az emberközpontú tervezés aspektusaival (Schön et al. 2017).

\section{A KUTATÁS ISMERTETÉSE}

\section{A kutatás célja és módszere}

A kutatás célja a különböző típusú szoftvertermékek előállítási folyamatának megismerése, hogy abban a gyakorlatban a felhasználóközpontú szempontok hogyan jelennek meg. A kutatás tehát a szoftverfejlesztés modelljeinek gyakorlati megvalósításaiban kívánja megtalálni a használhatóság és a felhasználói élmény szempontjainak és módszereinek szerves helyét.

A felhasználóközpontú szempontok fontosságának felismerése óta a témához köthetően számos publikáció jelent meg, de ezeknek a munkáknak a nagy része a téma elméleti hátterének az ismertetésével foglalkozik, így például az emberi tényezők számbavételének a fontosságát tárgyalja (Backhaus et al. 2014). A legújabb empirikus kutatások pedig egy-egy konkrét módszertan (például használhatósági vizsgálat), vagy eszköz (például hangos gondolkodás) gyakorlati használatának a lehetőségeit és korlátait ismertetik speciális szoftverekhez kapcsolható alkalmazási területekhez köthetően (May 2018, Brown \& Kim 2018). Nemzetközi szinten ennél átfogóbb, a jelenlegihez hasonló kutatásról csak Andersson (2012) munkája nyomán beszélhetünk, amely a UX területhez köthető tervezési irányelvek vállalati implementálásának a kérdéseit vizsgálja hasonló eszközökkel.

A jelen kutatás az előbbiekkel ellentétben nem egy módszer, vagy egy eszköz, vagy egy irányelv-csoport szoftverfejlesztési gyakorlatban való megjelenítését kutatja, hanem általában az emberközpontú folyamatok meglétét és milyenségét.

A szoftvercégek ilyen jellegü, jelenlegi gyakorlatának a fejlesztési folyamatok mentén történő komplex feltérképezése (alkalmazott modellek, a használhatósággal és felhasználói élménnyel kapcsolatos módszerek integráltság) így tehát tudományos szempontból valóban újszerü. Ez a kérdéskör egy a jelen kutatásra épülő, nagyobb (15-20 fős) interjúsorozat segítségével tárható fel. Mivel a magyar piacon igen jelentős és igen különböző szoftverfejlesztö vállalatok vannak jelen, így egy a hazai mintán elvégzett kutatás alkalmas a kérdés vizsgálatára.

Ez az összehasonlító, feltáró jellegü kvalitatív kutatás UX szakértőkkel, vagy hiányuk esetén fejlesztési vezetőkkel, projektvezetőkkel kerül elvégzésre a cégek valós gyakorlatának és a válaszadók témával kapcsolatos gondolkodásmódjának a megismerése érdekében.

Jelen cikk ennek a nagyobb kutatásnak a kutatási kérdéseit és elözetes eredményeit mutatja be öt igen különböző interjú kvalitatív összegzésének a segítségével. 


\section{Kutatási kérdések}

A szoftvercégek ugyan számtalan elöre definiált szempont (például vállalkozási forma, méret, bevétel; előállított szoftvertermékek típusa, funkciója, kereskedelmi kategóriája) szerint csoportosíthatók, de jelen kutatás szempontjából releváns kérdés az is, hogy milyen típusú vállalatok azonosíthatók az alkalmazott fejlesztési modellek tekintetében. A kisebb létszámú szoftveres cégeknél (tipikusan mikro-, vagy kisvállalatoknál) előfordulhat, hogy a fejlesztés ad hoc módon történik, így ott a különböző modellek használata várhatóan nem (vagy csak részben) jelenik meg. Az ennél nagyobb méretủ vállalkozásoknál pedig a hatékonyság növelése és a projektek nyomon követhetősége érdekében már a fejlesztési modellek, vagy az agilis elemek tudatos alkalmazása is biztosan megvalósul.

Központi kutatási kérdés az is, hogy a különböző szoftverpiaci szervezetek életében a felhasználóközpontú szempontok hogyan jelennek meg a fejlesztési folyamat lépései során, azokkal a szervezet mely szereplöje és milyen formában foglalkozik (1. ábra) (Szabó - Hercegfi 2017).

\section{1. ábra: A felhasználóközpontú szempontok és UX-es szereplók megjelenése a szoftvercégek életében}

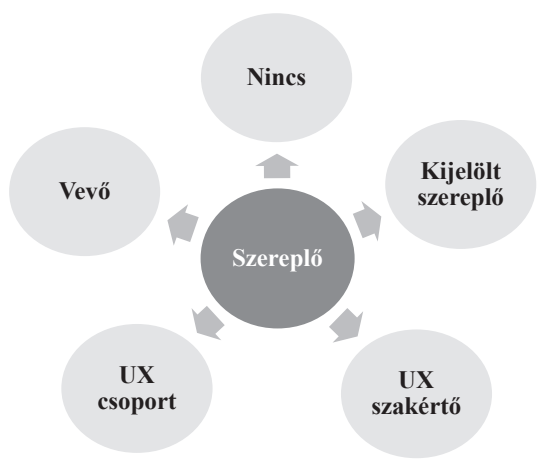

Forrás: saját szerkesztés

Az elmúlt években a felhasználói élmény tervezése és általában az emberi tényezők kulcsfontosságúvá váltak számos üzleti modellben (Salvendy 2012), de még mindig vannak olyan technológiai vállalatok, ahol ezek a faktorok nem töltenek be központi szerepet a szervezet életében. Az emberi tényezők figyelembevételének a hiánya komoly problémát jelent a különböző felhasználóközpontú módszertanok széleskörü elfogadása és alkalmazása tekintetében. Ezért ma már kialakításra kerültek olyan modellek is, amelyek különbözö, a felhasználói élménnyel összefüggésbe hozható aldimenziók mentén határozzák meg a szervezetek UX érettségét (Chapman \& Plewes 2014). Így jelen téma kapcsán a vizsgálat tárgyát képezi az is, hogy a különböző cégek mely szintre sorolhatók a UX érettségi modell értékelése szerint (2. ábra) (Fraser \& Plewes 2015) 

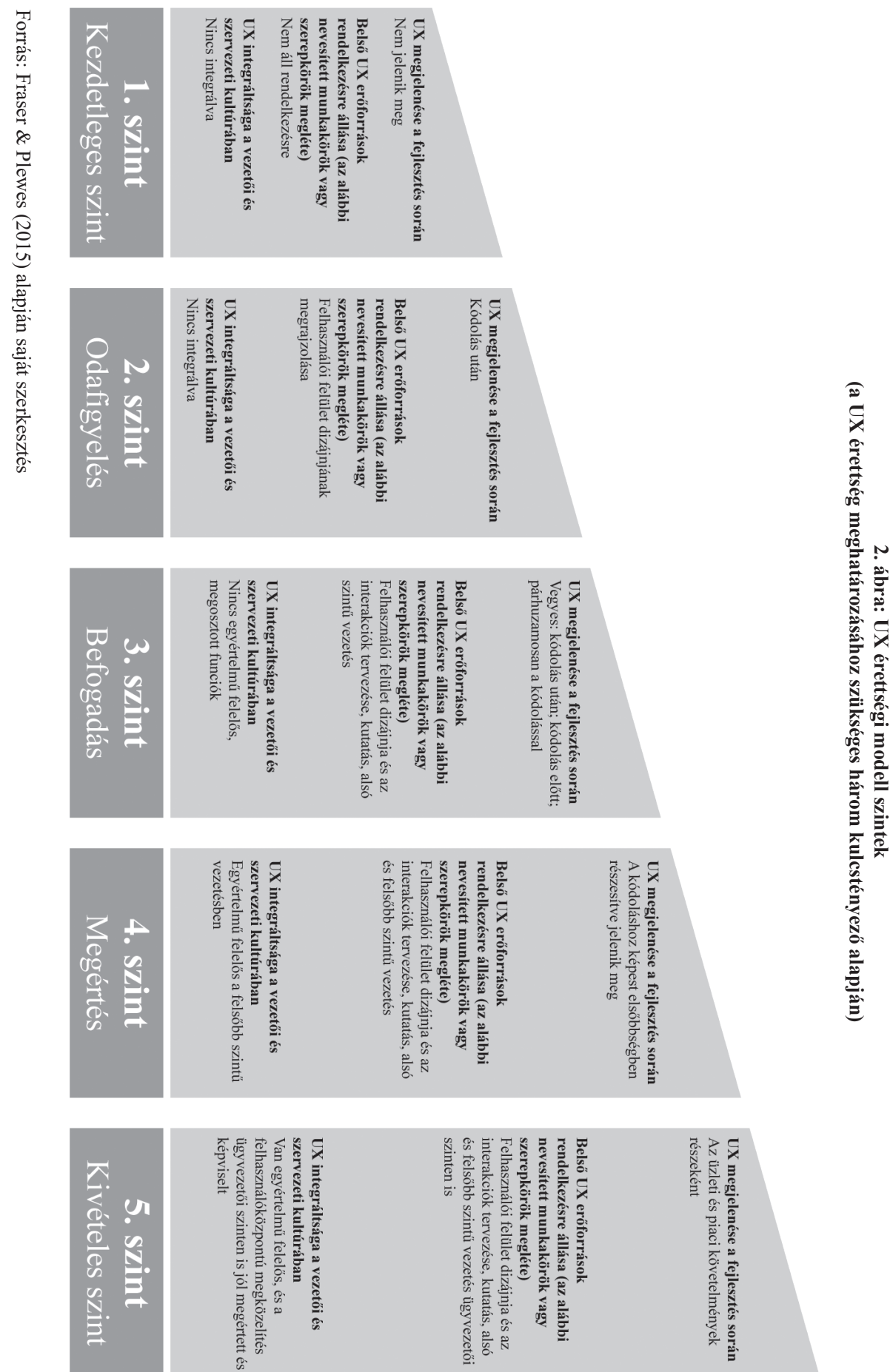


\section{EREDMÉNYEK}

A feltáró kutatás eredményei alátámasztják, hogy a különböző méretủ és profilú vállalatok müködése a szoftverfejlesztés egyes aspektusainak tekintetében valóban igen különböző módon működnek, illetve elmondható az is, hogy a kapott információk ismeretében a vállalatok UX érettségi besorolása elvégezhető a 3. ábrán szereplő három kulcstényező alapján.

Az előzetes elvárásoknak megfelelően a fejlesztés mindenhol eltérő lépések mentén történik, melyek a szakirodalmakban definiált életciklus modellekre (Mohapatra 2009) csak részben hasonlítanak, mivel azok gyakran egyedi tevékenységekkel és agilis elemekkel kerülnek kiegészítésre.

\section{Elsö vállalat}

Az első vállalat egy 300 fös középvállalkozás, ahol a szoftvertermékek elöállítása egy fejlesztő alapcsapat (core team), illetve piaci szakértők bevonásával történik. A fejlesztési igények vagy belsőleg (saját stratégia és vízió lapján) kerülnek megfogalmazásra; vagy pedig külső forrásból (ügyfelektől) származnak.

A szoftverfejlesztési folyamat első lépése a stratégiai tervezés, amelynek a lényege egy olyan verzióterv létrehozása, amely megfelel a vállalat stratégiai szintű elképzelésének. Ezután a második lépés a kickoff fázis, ahol tapasztalt szakemberek döntenek az elképzelés megvalósíthatóságáról. Ezt követi a tervezési szakasz, amelynek a célja a pontos követelmények meghatározása, a költségelemek becslésével egyetemben. A negyedik szakasz pedig a fejlesztés, amelynek akkor van vége, ha az a fejlesztési vezető és felelős designer által is jóváhagyásra került. A következő (release for testing) szakasz során belső és automatizált tesztelések zajlanak. A végső release (kiadás) akkor történik meg, ha a teszteredmények alapján már nem kell változtatásokat eszközölni.

\section{Második vállalat}

A második vállalat egy 1000 fő fölötti nagyvállalat, amelynél az interjúalany egyetlen termék felhasználói felületének kialakításával kapcsolatban tevékenykedik. A fejlesztési igények három forrásból (a $\mathrm{K}+\mathrm{F}$ osztály irányából, a piacról, vagy közvetlenül a megrendelőtől) származnak.

A fejlesztési folyamat megvalósithatósági tanulmányok kidolgozásával kezdődik. Ha ezek alapján engedélyezésre kerül, akkor elöször kis valósághüségủ (low fidelity) változatok - például szabadkézi vázlat (sketch), drótváz modell (wireframe) -, majd nagy valósághüségü (high fidelity) modellek - például makett (mockup) - készülnek, amelyekből prototípus készül (a szoftver még nem végleges, de már tesztelhető változata). A valósághűség dimenziója mentén eltérő változatok lehetővé teszik a felhasználók bevonását a tervezési folyamatba, így biztosítva a felhasználói felületek megfelelő irányú evolúcióját (Wong et al, 2012). A cégnél manuális és automatizált tesztelés is zajlik, amely eredményei alapján a prototípus a módosításra kerül a végső release előtt.

\section{Harmadik vállalat}

A harmadik vállalat egy 200 fős középvállalkozás, ahol a fejlesztési folyamat első fázisa a feltárás (discovery) szakasza. Itt különböző kutatási módszerekkel határozzák meg a pontos felhasználói igényeket. A cél a problématér alapos megismerése, tehát a probléma azonosítása és a megoldás definiálása, ami az ember-számítógép interakció területén a szoftver használatához szükséges kognitív és egyéb tevékenységek összességét érinti (Liu et al. 2014).

A következő fázis a szoftverépítés (build), amely a müszaki fejlesztések összességét takarja. Ha az megfelelőnek bizonyul a döntési kompetenciával rendelkező vezetők számára, akkor következhet a minőség-ellenőrzés, amelynek a célja, hogy a szoftvertermékek teljesek és konzisztensek legyenek (Schulmeyer 2008). Ezek után a folyamat utolsó lépése a visszamérés (measure), ami a kész szoftverváltozat konkrét adatokkal történő visszamérést takarja.

\section{Negyedik vállalat}

A negyedik nagyvállalatnál jelenleg 600 fö dolgozik egy olyan szoftver fejlesztésén, ami felhöalapú szolgáltatás formájában segíti egy adott szakterület napi munkáját. Itt a fejlesztési igények a felhasználóktól érkeznek, vagy a cég $\mathrm{K}+\mathrm{F}$ tevékenysége definiálja őket.

A termékfolyamat az üzleti/felhasználói igény megjelenésével kezdődik, ami a szoftverek B2B jellege miatt negyedéves ciklusokra van felosztva. A folyamat egy feltáró (discovery) résszel indul, ahol felhasználói és technológiai igényfelmérés, valamint érték (value) keresés történik. Majd ezt követi egy design sprint, ahol a csapat tagjai összeülnek, hogy pontosítani tudják az igényeket. A design sprint egy rugalmas terméktervezési 
keretrendszer, amely iterációs lépésekben biztosítja annak a valószínüségét annak, hogy olyan termék keletkezik, ami megfelelő a felhasználók számára (Banfield et al. 2016).

A termékvizió fázisban a design sprint eredmények alapján mockup változatok készülnek, majd definiálásra kerülnek a fejlesztői feladatok a technikai tervezés során. Ezután a fejlesztés, design kialakitás, majd a tesztelés következik. Release közelében pedig a szoftver próbavizsgálata (pilotolás) a folyamat utolsó lépése.

\section{Ötödik vállalat}

Az ötödik cég egy kisvállalat, amely B2B szoftvert fejleszt kereskedelmi cégek informatikai támogatása érdekében. A fejlesztési igények három forrásból származnak, így azok belsőleg fogalmazódnak meg, valamint a szoftverintegrálási folyamat áttekintési fázisában, vagy a tényleges használat közben keletkeznek.

A szoftverfejlesztési folyamat első lépése az igény megismerése, amit egy döntési pont követ, ahol mérlegelik a felmerülő igény megvalósíthatóságát. Pozitív elbírálás esetén következik a specifikáció elkészítése, amit a feladatok kiosztása, majd a tényleges fejlesztés, tesztelés és élesítés fázisa követ.

\section{Agilis módszertanok alkalmazása}

Az agilis fejlesztési módszertanok jelentős hatással vannak a szoftverfejlesztésre és a felhasználói szempontok alkalmazhatóságára, ezért a kutatás külön vizsgálja az agilis módszertanok gyakorlatban való megjelenésének módját és megítélését.

\section{Elsö vállalat}

Az első vállalat a szoftvertermékek fejlesztése során saját módszertannal dolgozik. Mivel az agilis módszertanoknál a „,tervezés kevésbé hangsúlyos” mint a vízesés modellnél, így ,hatékonyabb munkát eredményez”, így a menedzsment „bizonytalanságban él” azzal kapcsolatban, hogy milyen termék is készül pontosan. Ezért a fejlesztések során a vállalatnál két módszertan között egyensúlyoznak a hatékonyság és előreláthatóság közötti optimum megtalálása érdekében. Az interjúalany véleménye szerint az agilis fejlesztésben „komoly lehetőségek" vannak.

\section{Második vállalat}

A második vállalatnál a termék fejlesztése agilis módon valósul meg, a Scrum eszköztár elemeinek alkalmazásával. A Scrum egy keretrendszer, ami bizonyos mértékig szabályozza a hatékonyabb munkavégzés érdekében, hogy mi és hogyan tehető meg, a Scrum Master pedig az a szereplö, aki ennek a betartásáért felel (Larman 2004).

$\mathrm{Az}$ interjúalany véleménye szerint az agilis módszerek alkalmazásának előnye, hogy „lehetôvé teszi a csapaton belüli gyakori visszajelzést”, „,egyértelmúen leosztja a felelősségeket” és ,jól koordinálja a terhelést". Hátránya pedig, hogy „a fejlesztés sok lépésben érintkezik a megrendelővel", ami nehézséget okoz.

\section{Harmadik vállalat}

A harmadik vállalatnál a szoftverfejlesztés szintén a Scrum eszköztár elemeinek alkalmazásával valósul meg. Az interjúalany elmondása szerint „máshogy nem lehet fejleszteni”, csak és kizárólag agilis módon, különben összeomlik a termékfejlesztés. Ezen túl még azért is hasznos, mert „bizonyos szervezeti méret és komplexitás fölött már mindenképpen rendszerben kell gondolkozni”.

\section{Negyedik vállalat}

A negyedik vállalatnál a szoftverfejlesztés agilis módon történik, azon belül is az eXtreme Programming (XP) az, amit a leginkább alkalmaznak. Az XP egy szoftverfejlesztési módszertan, amelynek célja a változó körülmények mellett történő magas minőségü szoftver-előállítás. Az interjúalany véleménye szerint „,a UX csak és kizárólag ebben a formában lehet eredményes", mivel az agilis projektek fordítják a lehető legnagyobb figyelmet fordítják a felhasználói igények megismerésére (Babar et al. 2013).

\section{Ötödik vállalat}

Az ötödik vállalatnál a fejlesztések korábban a vízesés modell lépéseinek megfelelően zajlottak, ma már azonban saját fejlesztési módszertanokat követnek (például az agilis módszertani eszközöket szükebb határidőkkel alkalmazzák, gyorsabban reagálva a felmerülő fejlesztési igényekre). A megkérdezett elmondása szerint ,az agilis fejlesztés általánosságban a nagyobb szervezeteknél, hosszabb projekteknél hasznos". 


\section{Felhasználóközpontú szempontok megjelenése}

A cégeknél nemcsak a fejlesztési folyamatok különböznek egymástól, hanem a felhasználóközpontú szempontok is eltérő módon jelennek meg a különféle lépések mentén.

\section{Elsö vállalat}

Az első vállalatnál a szoftvertermék előállítása során a tervezési, fejlesztési és tesztelési szakaszokban is megjelennek a felhasználók 5-6 fös online fókuszcsoport keretein belül, ahol specifikációs elképzeléseket, köztes verziókat láthatnak. A szervezetnél tevékenykedő, felhasználói élménnyel foglalkozó 10 fös termékmenedzser csoport így biztosítja a folyamatos iterációt a felhasználókkal a fejlesztés során.

\section{Második vállalat}

A második vállalatnál a felhasználói felületek tervezése során a 3 fős UX-es csapat különbözö víziókat definiál, amelyekhez felhasználókat, majd perszonákat rendelnek. A perszonák tipizált felhasználók, amelyek kialakítása növeli a termékfejlesztési folyamat hatékonyságát (Miaskiewicz \& Kenneth 2011). Ezek után feladatuk a user journey map összeállítás, ami annak a folyamatnak a vizualizációja, amelyen egy felhasználó végighalad egy adott cél elérése érdekében (Rosenbaum et al. 2017). A cégnél a felhasználói felületek tesztelése belsőleg zajlik, heurisztikus módon.

\section{Harmadik vállalat}

A harmadik vállalatnál a 7 fös UX-es egység munkatársai egyszerre több csapattal, szorosan együttmúködve dolgoznak. Az interjúalany szerint a cég sikere a felhasználóközpontú szervezeti kultúrának köszönhető, ami a fejlesztési folyamatra is kihat, hiszen abban minden ponton megjelennek a felhasználók valamilyen módon. A felhasználók bevonása exploratív interjúkkal, megfigyelésekkel, a naplóírás technikájának alkalmazásával történik, valamint különféle használhatósági tesztelésre is sor kerül (sokszor RITE formában). A Rapid Iterative Test and Evaluation egy olyan módszer, ami - egy felhasználó bevonásával, az eredmények azonnali kiértékelésével, módosítások átvezetésével a gyors megoldások megtalálására fókuszál a problémák feltárása helyett (Medlock et al 2005).

\section{Negyedik vállalat}

A negyedik vállalatnál a különféle célokat OKR (Objectives and Key Results) rendszerben rögzítik. Az OKR egy keretrendszer, ami arra törekszik, hogy a közös gondolkozás és cél (itt olyan eredménytermék eloállítás, ami megfelel a felhasználói igényeknek) megléte révén biztosítsa az alkalmazottak együttmüködését, hogy erőfeszítéseikkel arra törekedjenek, hogy mérhető hozzájárulásokat tegyenek a vállalat sikereihez (Niven \& Lamorte 2016).

A fejlesztési folyamat során a 7 fös UX csapat munkatársai szabad eszköztárral dolgoznak, amelyek közül a naplózás, interjú, kontextusba helyezett megkérdezés, használhatósági vizsgálat az a módszer, ami a leggyakrabban megjelenik.

\section{Ötödik vállalat}

Az ötödik vállalatnál UX típusú feladatokkal nem foglalkozik senki. A cégnél a felhasználói felület tervezése egyfajta hagyománykövetési elv alapján müködik, ami azt jelenti, hogy van egy alap design és az egységesség érdekében az ott felhasznált stílust és kinézetet alkalmazzák, amely kialakítása során figyelembe vesznek különbözö felhasználóközpontú tervezési elveket is (például egér nélküli használat, átlátható képernyőképek). A tesztelés során a munkatársak mindig valós felhasználói teszteket szimulálnak.

\section{EREDMÉNYEK ÖSSZEGZÉSE}

Az előzetes eredmények jól szemléltetik, hogy a szoftverfejlesztési folyamatokban jelentős eltérések vannak, így a felhasználók bevonása is eltérő pontokon, más-más módszerek alkalmazásával tud megvalósulni (3. ábra) 


\section{3. ábra: A felhasználóközpontú szempontok megjelenése a vállalatok szoftverfejlesztési folyamataiban}

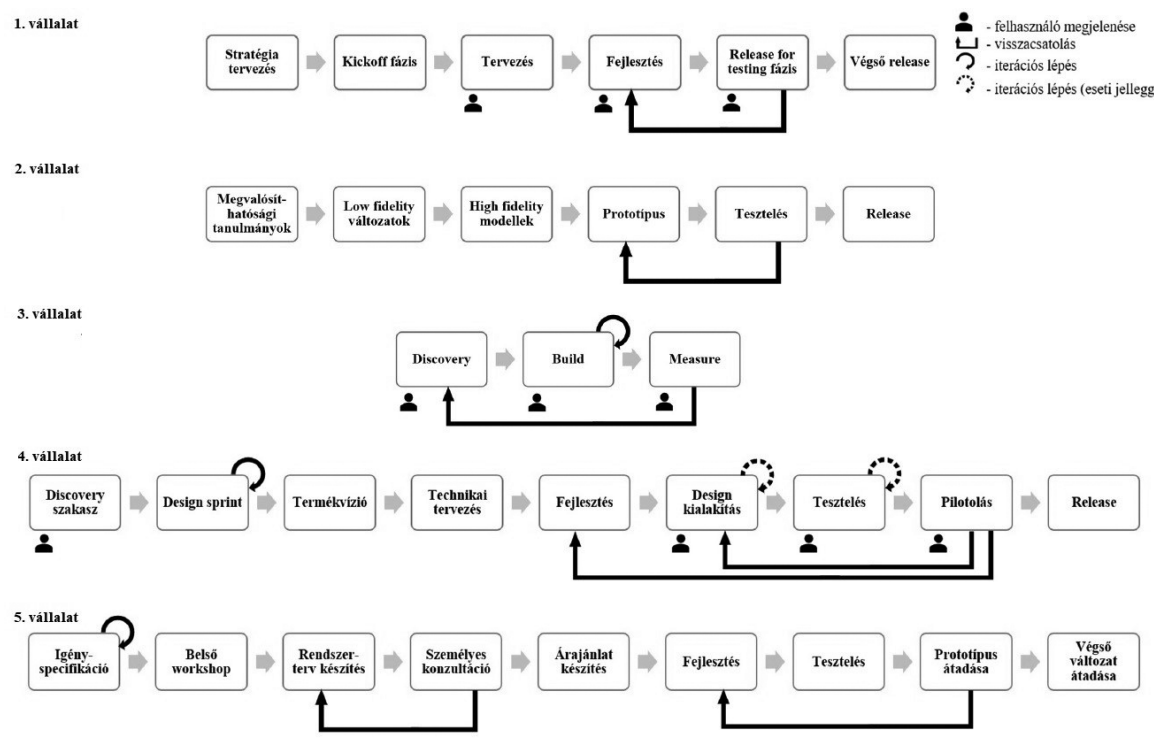

Forrás: Saját szerkesztés

A fejlesztések a legtöbb esetben agilis módon zajlanak (vagy egyedi módszertan mentén, agilis elemek átemelésével), de ennek ellenére azokban a vártnál kevesebb a visszacsatolás. Elmondható az is, hogy ugyan a vállalatok jelentős részénél már agilis módon fejlesztenek, de úgy tünik, hogy nem ez a tényező határozza meg a szervezetek UX-es érettségét. A második vállalat „tisztán” agilis müködés mellett 2-es, míg hasonló keretek között a negyedik szervezet már 5-ös szintre sorolható a Fraser-Plewes féle UX érettségi modell alapján.

A UX érettség magasabb (4-es és 5-ös szintre tehetö) azoknál a vállalatoknál, ahol a felhasználóközpontú megközelítéssel foglalkozó csapatok tevékenységeke a szervezet egészére kiterjedt. Itt a modell tényezőinek megfelelően a „Kivételes” szint elérése valóban azon cégekre lehet jellemzö, ahol a UX-es tevékenységek a fejlesztési folyamat minden lépése mentén jelen vannak. A feltáró kutatás eredményei alapján ehhez tipikusan 7 fös UX-es csapatra van szükség. Ennél kisebb létszám esetén (második vállalat) a felhasználóközpontúság nem tud megfelelően megjelenni a teljes szervezetben, míg nagyobb elemszámú csapat esetén a UX érettség alacsonyabb lehet (első vállalat). 


\section{1. táblázat - A kvalitatív kutatás eredményeit összefoglaló táblázat az első öt szoftvercég vonatkozásában}

\begin{tabular}{|c|c|c|c|c|c|}
\hline Azonosító & 1 & 2 & 3 & 4 & 5 \\
\hline Életkor & 25 év fölött & 25 év fölött & 10-15 év & 5-10 év & 20-25 év \\
\hline Létszám & 300 fö & 1000 fö fölött & 200 fö & 600 fö & 40 fö \\
\hline Vállalati kategória & Nagyvállalat & Nagyvállalat & Középvállalat & Nagyvállalat & Kisvállalat \\
\hline $\begin{array}{l}\text { Tulajdonosi } \\
\text { megoszlás }\end{array}$ & $\begin{array}{c}\text { Multi- } \\
\text { nacionális }\end{array}$ & $\begin{array}{c}\text { Multi- } \\
\text { nacionális }\end{array}$ & $\begin{array}{c}\text { Transz- } \\
\text { nacionális }\end{array}$ & $\begin{array}{c}\text { Multi- } \\
\text { nacionális }\end{array}$ & $\begin{array}{c}\text { Transz- } \\
\text { nacionális }\end{array}$ \\
\hline Profil & $\mathrm{B} 2 \mathrm{~B}$ & B2B & $\mathrm{B} 2 \mathrm{C}$ & $\mathrm{B} 2 \mathrm{~B}$ & $\mathrm{~B} 2 \mathrm{~B}$ \\
\hline Szoftver típusa & $\begin{array}{l}\text { Dobozos } \\
\text { szoftver } \\
\text { egy széles } \\
\text { szakmai kör } \\
\text { számára }\end{array}$ & $\begin{array}{l}\text { Felhőalapú } \\
\text { szoftver egy } \\
\text { szük szakmai } \\
\text { kör számára }\end{array}$ & $\begin{array}{l}\text { Felhőalapú } \\
\text { szoftver } \\
\text { elsősorban } \\
\text { magánszemé- } \\
\text { lyek számára }\end{array}$ & $\begin{array}{l}\text { Felhőalapú } \\
\text { szoftver egy } \\
\text { szük szakmai } \\
\text { kör számára }\end{array}$ & $\begin{array}{l}\text { Felhőalapú } \\
\text { szoftver, } \\
\text { egyedi } \\
\text { tanácsadás- } \\
\text { sal / testre } \\
\text { szabással egy } \\
\text { szűk szakmai } \\
\text { kör számára }\end{array}$ \\
\hline $\begin{array}{l}\text { Agilis szoftverfej- } \\
\text { lesztési módszertan } \\
\text { alkalmazása }\end{array}$ & $\begin{array}{c}\text { Részben } \\
\text { agilis }\end{array}$ & Agilis & Agilis & Agilis & Iteratív \\
\hline $\begin{array}{c}\text { UX megjelenése a } \\
\text { fejlesztési } \\
\text { folyamatban }\end{array}$ & Formális & Formális & Formális & Formális & Ösztönös \\
\hline UX csapat létszáma & 10 fó & 3 fö & 7 fó & 7 fó & - \\
\hline $\begin{array}{l}\text { UX tevékenység } \\
\text { kiterjedtsége }\end{array}$ & $\begin{array}{c}\text { Egész } \\
\text { szervezetre }\end{array}$ & $\begin{array}{l}\text { A szervezet } \\
\text { egy részére }\end{array}$ & $\begin{array}{c}\text { Egész } \\
\text { szervezetre }\end{array}$ & $\begin{array}{c}\text { Egész } \\
\text { szervezetre }\end{array}$ & - \\
\hline $\begin{array}{c}\text { Felhasználók } \\
\text { bevonása }\end{array}$ & $\begin{array}{l}\text { Tervezés, } \\
\text { fejlesztés, } \\
\text { tesztelés }\end{array}$ & - & $\begin{array}{l}\text { Minden } \\
\text { ponton }\end{array}$ & $\begin{array}{l}\text { Minden } \\
\text { ponton }\end{array}$ & - \\
\hline $\begin{array}{l}\text { Alkalmazott } \\
\text { felhasználóközpontú } \\
\text { módszerek }\end{array}$ & $\begin{array}{l}\text { Online } \\
\text { fókuszcso- } \\
\text { port, hasz- } \\
\text { nálhatósági } \\
\text { tesztelés }\end{array}$ & $\begin{array}{c}\text { Saját analiti- } \\
\text { kus módszer, } \\
\text { irányelvekkel } \\
\text { való ütközte- } \\
\text { tés (guideline } \\
\text { review) }\end{array}$ & $\begin{array}{l}\text { Interjú, hasz- } \\
\text { nálhatósági } \\
\text { vizsgálat }\end{array}$ & $\begin{array}{l}\text { Megfigye- } \\
\text { lés, interjú, } \\
\text { kontextusba } \\
\text { helyezett } \\
\text { megkérdezés, } \\
\text { használható- } \\
\text { sági vizsgálat }\end{array}$ & $\begin{array}{l}\text { Vásárlóköz- } \\
\text { pontú fókusz- } \\
\text { csoport }\end{array}$ \\
\hline UX érettség & 4 & 2 & 5 & 5 & 1 \\
\hline
\end{tabular}

Forrás: Saját szerkesztés 
Az első táblázat alapján további eltérések azonosíthatók a fejlesztés során megkérdezett felhasználók számában, illetve a bevonásuk során alkalmazott módszerek tekintetében is. Jelen kutatás alapján a legtöbb felhasználó bevonásával müködő (harmadik) vállalatról elmondható, hogy B2C terméket gyárt, szélesebb felhasználói kör számára, így az előállított szoftvertermék típusa több dimenzió mentén befolyásolhatja a szervezetek UX-es érettségét.

A kapott eredmények alapján kijelenthetö, hogy az empirikus módszereket alkalmazó középés nagyvállalatok (első, harmadik és negyedik szervezet) a méretüktöl függetlenül tudatosabban és sikeresebben implementálták a UX-es folyamatokat, amely során a saját müködésüknek megfelelő felhasználóközpontú módszereket alkalmazzák. Az eszköztár igen vegyes, így azok között jelen van felhasználói megfigyelés, interjú, online fókuszcsoport és a kontextusba helyezett megkérdezés is, míg közös jellemző a különböző pontokon megjelenő használhatósági vizsgálatok alkalmazása.

Az eredmények alapján elmondható az is, hogy a szervezeti méret, illetve a vállalati besorolás alapján az 50 fö alatt kisvállalatok azok amelyek a felhasználóközpontú megközelítések implementálását bizonyos korlátok mellett tudják csak alkalmazni. Az ilyen cégek közös jellemzője, hogy a felhasználók bevonása helyett inkább a vásárlók megkérdezésére törekednek a müködésük során, tehát a felhasználóközpontúság csak ösztönös módon van jelen a fejlesztési folyamatokban.

\section{ÖSSZEFOGLALÁS ÉS KITEKINTÉS TOVÁBBI KUTATÁSOKRA}

Jelen feltáró jellegű, kvalitatív kutatás alátámasztja a szoftveres cégek sokszínű működését és azt, hogy azonosíthatók olyan tényezök, amelyek befolyásolhatják a felhasználóközpontú szempontok alkalmazhatóságát és a szervezeti UX érettség szintjét. Ezek a feltételezett összefüggések az interjúk elemszámának növelésével hipotézisek formájában fogalmazhatók meg, amelyek kérdöíves megkérdezés segítségével statisztikailag is igazolhatók, vagy cáfolhatók. Ez a kutatás a 15-20 fös mintán elvégzett interjús megkérdezés után UX-es szakmai közösségekben terjesztve kerül majd kiküldésre a kérdéskör kvantitatív vizsgálata érdekében. 


\section{HIVATKOZÁSOK}

Andersson, S. (2012), Development and Implementation of User Experience Interaction Guidelines, Uppsala: Uppsala Universitet

Babar, M. A., Brown, A. W., Mistrik, I. (2013), Agile Software Architecture: Aligning Agile Processes and Software Architectures, San Francisco: Morgan Kaufmann Publishers DOI: https://doi.org/10.1016/C2012-0-01208-2

Backhaus, N., Brandenburg, S., Trapp, A. (2014), „Positive Technology and User Experience for Human Needs in Developing Countries: Some Considerations", in: Marcus, A. (ed.), Design, User Experience, and Usability. User Experience Design Practice: 3rd International Conference, Heraklion: Springer, 400-10 DOI: https:// doi.org/10.1007/978-3-319-07635-5_39

Banfield, R., Lombardo, C. T., Trace, T. (2016): Design Sprint - A Practical Guidebook for Building Great Digital Products, California: O'Reilly Media

Birrell, N. D. and Ould, M.A. (1988): A practical handbook to software development; Cambridge University Press. ISBN 978-0521347921. 3-12

Boehm, B. W. (1988), "A spiral model of software development and enhancement", Computer, 21 5, 61-72 DOI: https://doi.org/10.1109/2.59

Boehm, B., Egyed, A., Kwan, J., Port, D., Shah, A., Madachy, R. (1998), "Using the WinWin Spiral Model: A Case Study", Computer, 31 7, 33-44 DOI: https://doi.org/10.1109/2.689675

Brown, J., Kim, H. N. (2018), "Usability of Alzheimer's mHealth Applications", Journal of Best Practices in Health Professions Diversity: Education, Research \& Policy, 62 1, 503-7

Capretz, L. F. (2014), „Bringing the human factor to software engineering", IEEE Software, 312 , 102-4 DOI: https://doi.org/10.1109/ms.2014.30

Chapman, L., Plewes, S.: (2014), „A UX Maturity Model: Effective Introduction of UX into Organizations", in: Marcus A. (eds.), Design, User Experience, and Usability. User Experience Design Practice, 3rd International Conference, Heraklion: Springer, 12-23 DOI: https:// doi.org/10.1007/978-3-319-07638-6_2

Denning P. J., Gunderson C., Hayes-Roth R. (2008), „Evolutionary system development”, Communications of the ACM, 51 12, 29-31

Dingsøyr, T. - Nerur, S. - Balijepally, V. - Moe, N. B. (2012): „A decade of agile methodologies: Towards explaining agile software development." The Journal of Systems and Software 85 6, 1213-1221 DOI: https://doi.org/10.1016/j. jss.2012.02.033
Fraser J., Plewes S. (2015), „Applications of a UX Maturity Model to Influencing HF Best Practices in Technology Centric Companies: Lessons from Edison", Procedia Manufacturing, 3 626-31 DOI: https://doi.org/10.1016/j. promfg.2015.07.285

Fowler, M., Highsmith, J. (2001), "The agile manifesto", Software Development, 9 8, 28-35

Gorton, I., Heinemann, G. T., Crnkovic, I., Schmidt, H. W., Stafford, J. A., Szyperski, C., Wallnau, K. (eds.) (2006), Component-Based Software Engineering: 9th International Symposium, Västeras: Springer

Hassenzahl, M., Tractinsky, N. (2006), „User experience - a research agenda", Behaviour \& Information Technology, 25 2, 91-7 DOI: https://doi. org/10.1080/01449290500330331

Hercegfi K. (2005), Multimédia oktatóanyag fejlesztésének és bevezetésének minöségbiztositási kérdései. Budapest: BME Gazdálkodásés Szervezéstudományok Doktori Iskola

ISO 9241-210 (2010), Ergonomics of human-system interaction, Part 210: Human-centred design process for interactive systems, Berlin: Deutsches Institut für Normung

Kruchten, P. (2000), The Rational Unified Process An Introduction, Boston: Addison-Wesley

Law, E. L. C., Roto, V., Hassenzahl, M., Vermeeren, A. P., Kort, J. (2009), „Understanding, scoping and defining user experience: a survey approach", Proceedings of the SIGCHI conference on human factors in computing systems, Boston: ACM, 719-28 DOI: https://doi. org/10.1145/1518701.1518813

Lee, M C., Chang, T. (2006), „Applying TQM, CMM and ISO 9001 in knowledge management for software development process improvement" International Journal of Services and Standards, 2 1, 101-15 DOI: https://doi. org/10.1504/ijss.2006.008161

Lenberg, P., Feldt, R., Wallgren, L. G. (2014), „Towards a behavioral software engineering", Proceedings of the 7th international workshop on cooperative and human aspects of software engineering, Hyderabad: ACM, 48-55 DOI: https://doi.org/10.1145/2593702.2593711

Larman, C. (2004), Agile and iterative development: a manager's guide. Boston: Addison-Wesley Professional

Liu, C., Cheng, R., Meng, S. (2014), ,An Observation of Problem Spaces Based on Human-Computer Interactions", The Open Cybernetics \& Systemics Journal, 8, 139-45 DOI: https://doi. org/10.2174/1874110x01408010139 
May, J. (2018), „YouTube Gamers and ThinkAloud Protocols: Introducing Usability Testing", IEEE Transactions on Professional Communication, 1-10 DOI: https://doi.org/10.1109/ tpc.2018.2867130

Medlock, M. C., Wixon, D., McGee, M., Welsh, D. (2005), ,The Rapid Iterative Test and Evaluation Method: Better Products in Less Time", in: Cost-Justifying Usability, San Francisco: Morgan Kaufmann, 489-517 DOI: https:/doi. org/10.1016/b978-012095811-5/50017-1

Miaskiewicz, T., Kenneth, A. K. (2011), „Personas and user-centered design: How can personas benefit product design processes?", Design Studies, 32 5, 417-30 DOI: https://doi. org/10.1016/j.destud.2011.03.003

Mohapatra, P. K. J. (2009), Software Engineering: a Lifecycle Approach, New Delhi: New Age International Publishers

Munassar, N. M. A., Govardhan, A. (2010), “A comparison between five models of software engineering", International Journal of Computer Science Issues, 7 5, 94-101

Niven, P. R., Lamorte, B. (2016), Objectives and Key Results: Driving Focus, Alignment, and Engagement with OKRs, New Jersey: Wiley DOI: https://doi.org/10.1002/9781119255543

Rosenbaum, M. S., Otalora, M. L., Ramírez, G. C. (2017), "How to create a realistic customer journey map”, Business Horizons, 60 1, 143-50 DOI: https://doi.org/10.1016/j.bushor.2016.09.010

Rosove, P. E. (1967), Developing Computer-Based Information Systems, New York: Wiley

Royce, W. W. (1970): "Managing the Development of Large Software Systems", Technical Papers of Western Electronic Show and Convention, Los Angeles: ACM

Rubin, J., Chisnell, D., Spool, J. (2008), Handbook of Usability Testing: How to Plan, Design, and Conduct Effective Tests, New Jersey: Wiley
Salvendy, G. (2012), Handbook of Human Factors and Ergonomics, New Jersey: Wiley

Seffah, A, Gulliksen, J., Desmarais, M. C. (2005): Human-Centered Software Engineering: Integrating Usability in the Software Development Lifecycle, Dordrecht: Springer DOI: https://doi. org/10.1007/1-4020-4113-6

Schön, E. M., Thomaschewski, J., Escalona, M. J. (2017): „Agile Requirements Engineering: A systematic literature review", Computer Standards \& Interfaces, 49 1, 79-91 DOI: https://doi. org/10.1016/j.csi.2016.08.011

Schulmeyer, G. G. (2008): Handbook of Software Quality Assurance, London: Artech House Inc

Sharp, H., Rogers, Y., Preece, J. (2007), Interaction design: Beyond human-computer interaction. New Jersey: Wiley

Sikorski, M. (2012), User-System Interaction Design in IT projects, Gdansk: Gdansk University of Technology

Szabó, B. - Hercegfi, K. (2017), „Research questions on integrating user experience approaches into software development processes", in: Baranyi, P. (ed.), 8th IEEE International Conference on Cognitive Infocommunications, Debrecen: IEEE, 243-6 DOI: https:/doi. org/10.1109/coginfocom.2017.8268250

Tenner, A. R., DeToro, I. J. (1992), Total quality management: Three steps to continuous improvement, Addison-Wesley

Wong, M. L., Khong, C. W., Thwaites, H. (2012): „Applied UX and UCD Design Process in Interface Design", Procedia - Social and Behavioral Sciences, 51 703-8 DOI: https://doi. org/10.1016/j.sbspro.2012.08.228 
Szabó Bálint, tudományos segédmunkatárs szabobalint@erg.bme.hu

Budapesti Müszaki és Gazdaságtudományi Egyetem

Gazdaság- és Társadalomtudományi Kar

Ergonómia és Pszichológia Tanszék

\section{Different appearance of user-centred aspects in software development - Qualitative research on the practice of domestic companies}

\section{THE AIMS OF THE PAPER}

The aim of the research is to deepen the knowledge on the production process of various software product types, including the detailed examination of how user-centered aspects are applied in software development practice. Therefore, the research aims to explore the role of the usability and User eXperience (UX) factors in the practical implementations of software development models.

\section{METHODOLOGY}

The current practice of software companies can be explored through interview series. A research performed on a sample of 15-20 professional leaders is a good starting point to learn the practice of companies and the attitude of the respondents toward the topic. This paper presents the research questions and preliminary results of this larger research through the qualitative summaries of six very different interviews.

\section{MOST IMPORTANT RESULTS}

Preliminary results show that there are significant differences in software development processes. They are implemented various ways, with the use of several tools, so that users can be involved at different points, using different methods. Developments in most cases are agile, althought, feedback was less than expected. Although in most companies the developments are already agile, but this factor does not seem to determine the UX maturity level of organizations. UX maturity is higher in companies where the user-centered approach activities have been extended throughout the organization. Besides, based on the results, it seems that medium and large enterprises using empirical methods have implemented the UX processes more consciously and successfully, regardless of their size. Based on the results, it can be stated that, according to organizational size and corporate classification, small businesses below 50 employees are those that can only apply the implementation of user-centred approaches under certain limits.

\section{RECOMMENDATIONS}

Overview and synthesis of the various UX practices are useful for future decision-makers of different companies, and a systematic overview of the methodologies used in the software market is also novel from a scientific point of view.

Keywords: User eXperience (UX), human factors, software development, UX maturity 


\title{
Egyetemi promóció optimalizálás dinamikus programozással
}

\author{
Molnárné Konyha Csilla \\ Miskolci Egyetem
}

\section{A TANULMÁNY CÉLJA}

Jelen tanulmány célja az úgynevezett egyetemi promóció optimalizációs modell (UNIPOM) részletes bemutatása, amely a beiskolázási kampányra fordítandó szükös erőforrás esetén is a lehető leghatékonyabb marketing kommunikációs mix összeállítását teszi lehetővé egy erre a célra létrehozott szoftver segítségével.

\begin{abstract}
ALKALMAZOTT MÓDSZERTAN
Longitudinális vizsgálat, fókuszcsoportos interjú, kérdőívvel támogatott megkérdezés, szakértői mélyinterjú, dinamikus programozás
\end{abstract}

\section{LEGFONTOSABB EREDMÉNYEK}

A kutatás legfontosabb eredménye az úgynevezett egyetemi promóció optimalizációs modell (UNIPOM) megalkotása, amely lehetővé teszi a leghatékonyabb beiskolázási promóciós mix létrehozását szükös büdzsé esetén is.

Az így létrehozott marketingkommunikációs mix választ ad arra a kérdésre, hogy melyik hónapban milyen eszközöket használjanak az egyetemek egy beiskolázási kampány keretén belül.

Az eszközök szükítésére létrehozott UNIPOM modell és a modellre épülő szoftver az összes beiskolázásra használt eszköz megvásárlásához szükséges keretösszeg feléből is már $90 \%$ feletti hasznosságot realizál. (100\% hasznosság alatt az összes eszköz megvásárlásával elérhető hasznosságot értünk.)

\section{GYAKORLATI JAVASLATOK}

Fontos megjegyeznünk, hogy jelen tanulmányban részletezett egyetemi optimalizációs modell alkalmazását mindössze döntés támogatói céllal hoztuk létre a felsőoktatásban dolgozó beiskolázással foglalkozó szakértők számára. Bízunk abban, hogy hasznosnak találják majd egy sikeres beiskolázási kampány létrehozásához, stratégiájuk megalapozásához.

Kulcsszavak: felsőoktatási marketing, hallgatók toborzása, promóció optimalizációs modell (UNIPOM), hátizsák probléma 


\section{BEVEZETÉS}

A Magyarországon megfigyelhetö folyamatos népességcsökkenés mellett a hallgatói létszám is folyamatos csökkenést mutat 2012-töl egészen 2017-ig (KSH 2018), idén az elöző évhez képest kisebb arányú növekedés volt tapasztalható jelentkezők (1,7\%-os növekedés) és a felvettek számában (3,4\% növekedés) (Felvi.hu 2018).

Polónyi (2016) szerint a hallgatói létszám drasztikus csökkenése nem csupán a 18 éves korosztály csökkenésével indokolható, mivel az újonnan belépő hallgatók csökkenése mintegy kétszerese a demográfiai folyamatokkal magyarázható csökkenésnek. Az apadás okát az államilag finanszírozott föiskolai és egyetemi férőhelyek visszaszorítására vezette vissza.

A felsőoktatási intézmények között élesedő verseny hosszútávon intézmények bezáráshoz is vezethet. A verseny fokozódásához a globalizáció is hozzájárul, ugyanis a rohamosan fejlödő IT technológiáknak köszönhetően az információ gyorsabb áramlása zajlik: a magyar felsőoktatási intézményeknek számára a hazai intézményeken kívül már a külföldi egyetemek és föiskolák is tényleges versenytársakká váltak.

Az egyre erősödő versenyhelyzetet felismerve a felsőoktatás intézmények belekezdtek a márkaépítésbe, a sajtókommunikáció tudatos alkalmazásába, az internet térnyerésének köszönhetően online marketinget alkalmaznak és marketingrendezvényeket szerveznek. (Kovácsné Tóth és Zakariás 2010)

\section{HATÉKONYSÁG ÉS \\ HASZNOSSÁG, HATÁSOSSÁG ÉS EREDMÉNYESSÉG FOGALMAK ÉRTELMEZÉSE:}

A hatékonyság, hatásosság, eredményesség és hasznosság kulcsszavak az UNIPOM modellel kapcsolatban többször említésre kerülnek, ezért értelmezésük tisztázása a kutatás szempontjából releváns.

Hatásosság alatt azt értjük, hogy „,a vállalati teljesitmény milyen mértékben közelíti meg az ideális célokat". Ilyen célok lehetnek a márkaismertség növelése, piaci pozíció növelése, stb. (Gyulavári és Hubert 2014, 302) Az eredményesség fogalmát gyakran használják átfedésben a hatékonyság, hatásosság, jövedelmezöség, termelékenység és versenyképesség fogalmakkal és gyakran a hatásosság fogalmával azonosítják (Katona 2015). A tanulmányban az eredményes- ség fogalmát Wimmer (2002, 5) értelmezésének megfelelően használom, aki a „céloknak való megfelelés"-ként definiálja.

Hubert $(2016,43)$ a hatékonyságot a következőképpen definiálja: ,, a cég teljesitménye és a teljesitmény eléréséhez felhasznált ráforditások közötti dinamikus viszonyszám, ami jellemzöen valamilyen bázishoz (to idöszak, versenytárs terméke, saját cég másik terméke, stb.) mérten jellemzi a cég egészének vagy egy konkrét vállalati részterület müködését".

A hasznosság közgazdasági értelemben „a javak és szolgáltatások elfogyasztásából származó teljes elégedettség, jólétérzet”, míg a hatékonyság ezzel szemben „, a veszteségek elkerülése, másként a gazdasági eröforrások olyan felhasználása, amely maximális eredményre vezet $a z$ adott eröforrás-mennyiség és a technológiai szinvonal mellett." (Samuelson \& Nordhaus 2012, 598-599)

A marketingkommunikációs eszközök hatékony alkalmazásának igénye az oktatásban is megjelent.

Marketinghatékonyság alatt olyan minőséget értünk, amelynek segítségével a menedzserek úgy lépnek a piacra, hogy optimalizálják a költésüket annak érdekében, hogy jó eredményeket érjenek el mind rövid-, és hosszútávon. A marketing hatékonyságot úgy is definiálják, mint a költség minőségének optimalizálását, amelynek segítségével rövidtávon elérhetjük a kívánt eredményeket. (Solcansky \& Simberova 2010)

A továbbiakban a marketinghatékonyságot Solcansky és Simberova megközelítésében értelmezzük. A hasznosság a modellben az igénybevett információforrások használati intenzitásával írható le, melynek pontos részletezése a modell bemutatásában megtalálható.

\section{Továbbtanulással kapcsolatos információforrások}

Az UNIPOM modellbe vett továbbtanulással kapcsolatos információforrások egy részét a releváns nemzetközi és magyar szakirodalmon segítségével gyüjtöttük össze. „Az információgyüjtés, s annak szelektálása sokelemü és többnyire hosszú folyamat, igen eltérö intenzitással, melynek minden fázisát célszerü marketingaktivitással befolyásolni." (Piskóti 2017, 119)

A továbbtanulásban a referenciacsoport (barátok, rokonok, család, ismerősök és a középiskolai tanárok) fontos információt biztosít a potenciális hallgatók számára, ha az egyetemválasztásról van szó (Kuráth 2008, Piskóti 2008, Kéri 2016). A csoport tagjai akár az egyetem jó 
hírneve miatt, vagy saját tanulmányaikból kifolyólag is ajánlhatják az adott intézményt. Egy 2015 ben készült tanulmány szerint a jelenlegi hallgatók és szülők véleménye a legkiemelkedőbb a referenciacsoportból (Manoku 2015).

A televízió szerepe a beiskolázási marketingben nem számít tipikusnak, ennek oka lehet, hogy az ott közvetített reklámok meglehetősen drágák. Egy lehetséges alternatíva, amikor az adott intézmény vezetőjét kérdezik a feltételiről az adott egyetemen, főiskolán. Sok esetben a hallgatóság a reklámblokk kezdetén azonnal elkapcsolja a televíziót, vagy inkább megállítja a tévét (zapping jelenség). Fontos megemlítenünk továbbá, hogy egy 2015-ös felmérés során a 18-29 évesek mindössze 47\%-a néz tévét napi szinten, míg 81\%-uk használja az internetet minden nap (Hack-Handa és Pintér 2015), mindazonáltal a tévénézők 55\%-a szokott a tévénézéssel párhuzamosan internetezni (Consumer Barometer 2018).

A fiatalok médiafogyasztásának, életvitelének folyamatos változása miatt a rádió szerepe is átalakult, hallgatóságának fogyasztási szokásai különös tekintettel a mai fiatal generációra - megváltozott. A mai generációra nem jellemző a rádióadások hallgatása, helyette az interneten hallgatják kedvenc számaikat. (Csipkés és Bácsi 2018)

$\mathrm{Az}$ egyetemek, főiskolák által rendezett programok közül a felvételi kiállítások (Pl. Educatio), nyíltnapok, középiskolai látogatások, egyéb programok (pl. Kutatók éjszakája) mind hatásos információforrások lehetnek a potenciális hallgatók elnyerésében. Nyílt napot szinte mindegyik külföldi, illetve hazai intézmény rendez, azonban alkalmazása hiányolja a tudatos elemzést. (Kun és Svanter 2014)

Tradicionális eszközöknek számítanak a beiskolázásban továbbá a szórólapok, óriásplakátok és brosúrák. Habár használatuk megszokott, innovatív, interaktív felhasználásuk hozzájárulhat a felsőoktatási intézmény eredményes reklámozásához.

Egy 2018-as felmérés alapján nyomtatott sajtónak, nyomtatott médiumoknak jelentősége csökkent az internetes forrásokkal szemben, aminek legföbb oka az, hogy a fiatalok által kedvelt újságok java része megtalálható online is (Csipkés és Bácsi 2018). Az egyetem saját kiadványai, újságjait is kereshetik a potenciális hallgatók már a döntésük meghozatal elött, hogy ezzel is teljes képet kaphassanak a leendő intézményükről „Fontos, hogy az egyetemi szakmai kiadványok rendszerében érvényesüljenek a marketingszempontok is." (Piskóti 2011, 48)

A fiatal diákok megnyerése is egyre nehezebb lesz, hisz tudatosan reklámkerülők, azonban az új médiaeszközöket szívesen használják (Bányai és Dudás 2010). Az internet és föleg a közösségi média a legmegfelelőbb platform arra, hogy párbeszédet kezdeményezzen a potenciális hallgatókkal. (Marino and Presti 2016) „A fiatal korosztály tagjai körében vannak jelen azok a digitális bennszülöttek, akik mindennapjaik során a lehetö legtöbb tevékenységet online végzik, gyorsan, rutinszerüen, problémamentesen és magától értetödöen. " (Szíjártó és tsai 2018,59)

A közösségi média alkalmazása aligha hanyagolható el a beiskolázási kampány esetében, hisz a mai napig a fó kommunikációs csatornát jelenti a mai fiatalság számára. Egy 2018. januári adat szerint, mintegy 2,17 milliárd aktív felhasználója van a Facebooknak világviszonylatban, míg a Földünkön mintegy 7,5 milliárd ember él. Ami Magyarországot illeti, összesen 5,6 millió felhasználhatót lehet elérni rajta. (Lévai 2018)

A Facebookban rejlő lehetőségeket már több egyetem felismerte, rendelkezik saját profillal (Miskolci Egyetem, Debreceni Egyetem, Semmelweis Egyetem, stb.), valamint a beiskolázáshoz is használja nemcsak egyetemi, de kari és intézeti szinten egyaránt. Ezen a felületen az egyetem információt adhat a közelgő eseményekről, aktuális hírekröl, levetíthet kampányfilmeket, megoszthat fényképeket (például nyílt napról, kiállításokról), stb. A mai fiatalok hozzáállása változott a tartalomhoz, hisz ,nemcsakfogyasztják, de szivesen meg is osztják azt, és egyáltalán nem csak anyagiokokból, hanem sok esetben pusztán érdekesség vagy spontán „terméktámogatás” miatt”. (Hack-Handa és Pintér 2015, 15)

$\mathrm{Az}$ internetes kommunikációban szintén meg kell említeni az egyetemi honlapok jelentőségét, amelyek szintén dinamikus eszközöknek számítanak. (Kuráth 2008) A technológia gyors fejlödésével azonban a honlap látogatóinak igényei is változnak, amelyet folyamatosan nyomon kell követni és a honlapokat eszerint célszerü fejleszteni. A mai internetezési trendeknek megfelelően manapság a tartalmakhoz való hozzáférés javarészt mobiltelefonok segítségével történik, tehát az egyetemi honlapok esetében is fontos lett, illetve lesz, hogy a felület reszponzív legyen. Egy ilyen honlap megjelenése a képernyő méretének megfelelően változik, a mobiltelefonon keskeny oszlopszerü elrendezésben jelenik meg a tartalom (Garamvölgyi 2017).

$\mathrm{Az}$ iskolaválasztás folyamatában a felvételi portálok látogatása is fontos szerepet játszik, hisz például a felvi.hu-ról aktuális, naprakész információkat lehet szerezni. A felvi.hu népszerüsége annak tudható be, hogy az Oktatási Hivatal ezen 
az oldalon nyújt teljes körủ információt a felvételivel, induló szakokkal, és keretszámokkal kapcsolatban (Duga 2014). A felvi.hu látogatottsága havi szinten 200 és 500 ezer között mozog, a legintenzívebb hónapok egy 2015-ös adat alapján a január, február és július (Oktatási Hivatal 2016). A két téli hónap a felvételi határidő közeledésének tudható be, illetve a júliusi hónap pedig a felvételi eredmények megjelenésének az időszaka.

A keresőmotorok (Google, Yahoo) jelentősége is fontos lehet a beiskolázási marketing folyamatában. Minél elörébb szerepel egy honlap, annál jobb a megitélése. A helyezést kétféle módon lehet befolyásolni, egyrészt organikusan (keresőoptimalizálással), másrészt fizetett hirdetés formájában.

Vannak olyan főiskolák, egyetemek, amelyek saját applikációval rendelkeznek, amelyen keresztül a potenciális dikákokkal könnyebb a kommunikáció. (Például Nyíregyházi Föiskola, Kaposvári Egyetem). A hazai egyetemi, illetve föiskolai applikációkon keresztül ugyanúgy hozzá lehet férni minden információhoz, mint a felsőfokú intézmények honlapjain keresztül. A küldföldi egyetemek applikációi (például Newcastle University) ezen felül már olyan céllal lettek létrehozva, hogy a felvételt nyert diákok mindennapi életét is megkönnyítsék, beleértve vizsgák ütemezése, elért kreditek, kikölcsönzött és visszavitt könyvtári könyvek nyilvántartása, campus térképe (hogy a diákok jobban odataláljanak az órákra), elérhető számítógépek keresése, nyomtatási lehetőségek intézése appon belül, további hasznos tanulást segítő appok felajánlása, stb.

\section{Médiatervezö és elemzö szoftverek}

A különböző célokat szolgáló médiatervező és elemző szoftvereket már régóta használják a kommunikációs ügynökségek, azonban a felsőoktatási kampányok megtervezése során még nem került sor az alkalmazásukra. Az általuk használt módszerek tanulmányozása, fejlődésük nyomonkövetése, módszerük felhasználása új irányt eredményezhet a beiskolázási marketingkommunikáció tökéletesítésében. A kommunikációs ügynökségek által leggyakrabban használt szoftverek a következők:

- ABG Nielsen Médiakutató Arianna, Nielsen (AGB Nielsen 2018, Kosterich and Napoli 2016)

- A Millward Brown kutató cég szoftvere a Choices, segítségével két kutatás a TGI (Target Group Index - Célcsoport Index) és a NOK (Nemzetközi Olvasottság
Kutatás) adatbázisaira lehet rálátásunk, illetve elemezhetünk és tervezhetünk is vele igény szerint (Bogáromi - Máth 2015).

- Kantar Media: Instar Analytics. Instar Planning, Instar Social (Kantar Media 2018)

- A Gemius Explorer az online közönségmérésre fókuszál. (Gemius Hungary 2018)

\section{Alternativ média optimalizálási módszerek}

Jelenleg számos média optimalizálási modell áll rendelkezésre, amelyeket kommunikációra szánt költségvetés allokációjára hoztak létre, valamint, hogy megoldást nyújtsanak a média szelektálási problémára, illetve reagáljanak a piac változásaira.

Egy részük a mohó (greedy) algoritmusok (Nie and Kambhampati, 2001) módszerével optimalizál, ami annyit jelent, hogy egy (kis) média portfólióval indul és fokozatosan tölti fel olyan újabb kommunikációs eszközökkel (pl. újságok, magazinok, programok, stb.) amelyek az adott helyzetben a legjobb megoldást nyújtják (helyi optimum). Mindezt addig teszik, amíg meg nem találják a globális optimumot. Egy másik népszerü módszer az optimalizálásra a lineáris programozás, amelynek célja a lehető legnagyobb megtérülés elérése. A módszer lényege, hogy lineáris megkötéseket állít fel, pl. adott médiára költhető maximális befektetés, minimum TRP (az adott célközönség azon százaléka, akiket el lehet érni a reklám elérésével), büdzsé, és más mérőszámok tekintetében. (Brown and Warshaw, 1965) Bass és Londsdale (1966) a módszer alkalmazásakor a közönségi adatokat súlyozta az optimalizáláshoz. Charnes és társai (1968) a célprogramozás módszeréhez fordultak, hogy kiküszöböljék a gyakoriság és elérés mérésének a problémáját, mivel így részcélok meghatározására is lehetőség nyílik. Ilyen részcélként említhetjük meg a különböző szegmensek elérését is. Fernandez és társai (2007) létrehozták az úgynevezett átlagos variancia (mean variance) módszerét a TRP maximalizálására egy adott költségvetés mellett. A fuzzy optimalizálás olyan többcélú médiatervező eljárás, amivel mindennemü bizonytalanságot számszerüsíteni lehet.

A dinamikus programozás módszerének előnye a fentiekkel szemben az, hogy megengedi a hosszabb időhorizontok felosztását rövidebb periódusokra és a médiatervezési döntéseknél ezeket a változásokat is figyelembe vehetjük, így összetettebb tervezést is lehetővé teszünk (Aggarwal et 
al. 2017), ezek mellett megemlíthető a módszer egyszerűsége is, amely tökéletesen alkalmas az általunk lentebb részletezett probléma megoldására.

A dinamikus programozás fogalma eredetileg Richard Bellman (1954) nevéhez füződik, habár programozás alatt nem a számítógépes programozást érti, hanem sokkal inkább egy eljárást, egy gondolkodásmódot, többlépcsős folyamatok optimális megtervezését. A programozás szót eredetileg katonai értelemben használták, arra utalt, hogy egy optimális programot találjanak az edzésekre és a logisztikai teendőkre. (Nocedal és Wright 2006) A módszer olyan megoldást kínál, amelynek lényege, hogy a kiindulási problémát részproblémákra bontjuk és azok megoldásaival jutunk el a megoldásig. (Dasgupta et al. 2006) A megoldást rekurzívan fejezzük ki, azonban a tényleges számítás táblázat kitöltésével történik. „Egy objektum definícióját rekurzívnak nevezünk, ha a definíció tartalmazza a definiálandó objektumot." (Horváth, 2005, old.: 1) A kisebb problémákat csak egyszer oldjuk meg és azok megoldását tároljuk, amelyet memorizálásnak hívunk, meggyorsítva így a számítást. A dinamikus programozás algoritmusait gyakran használjuk optimalizáláshoz. Az algoritmus megvizsgálja az előzőleg megoldott részproblémákat és azok megoldásait kombinálja, hogy a legjobb megoldást kínálhassa az adott problémára. (Cormen et al. 2001) Az algoritmus mindeközben eltárolja a részproblémák megoldásait a memóriában, későbbi használatra, így nem kell megoldani (kiszámítani) a részproblémákat újból meg újból. A dinamikus programozást optimalizálási problémáknál szokták használni, ahol több lehetséges megoldás lehetséges, mindegyik megoldásnak van egy értéke, és azt a megoldást igyekszünk megtalálni, amely számunkra a legoptimálisabb (minimális vagy maximális) értékkel rendelkezik. (Cormen et al. 2001)

\section{Az UNIPOM modell módszertana}

Az alábbi adatsor képezi a felállításra került optimalizációs modell alapját. A kiinduló probléma képletekkel leírva:

(U=hasznosság, x, y, ..., z=különböző kommunikációs aktivitások különböző időpontokban)

( $\mathrm{I}=$ büdzsé, $\mathrm{P}=$ kommunikáció aktivitás költsége)

$\mathrm{x}, \mathrm{y}, \ldots, \mathrm{z}=$ ? (bináris együtthatók)

A képlet lényege, hogy a maximális hasznosságot (U) szeretnénk elérni a különböző kommunikációs eszközök segítségével (x,y....z), de sajnos a rendelkezésre álló pénzügyi keret véges és nem tudjuk megvenni az összes szükséges kommunikációs eszközt, szelektálni kell közülük az áruk és a hasznosságuk figyelembevételével.

A kommunikációs mix optimalizálása - előzetes vizsgálataink szerint - visszavezethető az operációkutatásban és az algoritmuselméletben jól ismert úgynevezett hátizsák problémára (Dantzig 1930, Mathews 1897).

Az alternatívák szúkítéséhez mindenféleképpen szükséges a kommunikációs eszközök, a kibocsátott információ leszükítése és a médiumok precíz megválasztása. Ebben nyújt segítséget a hátizsák feladat.

A kommunikációs eszközök nagy száma, ráadásul az, hogy a kommunikációs eszközök hasznosságát 12 hónapon keresztül havi szinten vizsgáltuk, lehetetlenné tette volna a kézi számítást, a hátizsák probléma megoldását. Ezért erre a célra létrejött egy szoftver.

\section{Az UNIPOM modellhez létrehozott szoftver}

A hátizsák problémával több operációkutatással kapcsolatos szakirodalom foglalkozik, (Bajalinov Imreh 2001, Temesi - Varró 2007, Vámossy 2012). A hátizsákfeladat megoldásárára több módszer áll rendelkezésre, amelyek a következők: szétválasztás és korlátozás módszere, implicit leszámolás, Gömöry-féle vágás és dinamikus programozás (Nagy 2007), A felsorolt módszerek közül dinamikus programozásával kíséreljük meg a feladat megoldását az erre létrehozott szoftver segítségével.

A kiinduló problémánk az, hogy az adott hátizsákunk egy bizonyos súlynál nem bír el többet, a mi esetünkben ez a súly a keretösszeg, amit adott kommunikációs eszközökre költhetünk el adott évben. Minden kommunikációs eszköz rendelkezik árral és hasznossággal, és figyelembe kell venni, hogy van egy keretösszeg, amit nem léphetünk át. A cél az, hogy a maximális hasznosságot el tudjuk érni úgy, hogy a rendelkezésre álló keretösszeg túlnyomó részt elköltésre kerüljön.

A felsorolt módszerek közül dinamikus programozásával kíséreljük meg a feladat megoldását az erre létrehozott szoftver segítségével.

\section{A szoftverbe betáplált adatok}

A szoftverbe minden egyes kommunikációs eszköz hasznosságát és árát betápláltuk, amelynek segítségével egy adott keretösszeg megadásával a legoptimálisabb választást ajánlja fel nekünk egy évre levetítve. A különböző eszközöket hónapokra 
lebontva külön tápláltuk be a szoftverbe, ezért ezeket külön kezelte a gép, mintha önálló eszközök lennének.

A kommunikációs eszközök hasznosságát egyrészről úgy állapítottuk meg, hogy a potenciális hallgatókat megkérdeztük arról, hogy milyen intenzitással vették igénybe vagy használták az adott továbbtanulással kapcsolatos információforrásokat. A válaszukat egy 0-tól 10-ig terjedő skálán kellett értékelniük. ( $0=$ egyáltalán nem vette igénybe, $1=$ alig használta ....10=kifejezetten sokat használta) Az eredmények átlagolásával jutottunk el az eszközök diákok által megítélt hasznosságához. Másrészről a szakértői mélyinterjún elhangzottak segítettek a hasznosságok pontosításában, hisz a megkérdezett kommunikációs szakember véleménye azonos súlyt kapott az információforrások értékelésében, mint a diákok megítélése.

\section{Előnyök}

Az egyetemi promóció optimalizációs modellnek hála (UNIPOM modell) a beiskolázási kommunikációra fordítható kisebb összegből is a leghatékonyabb kommunikációs mixet állíthatunk össze. Már a rendelkezésre álló összeg feléből is a legtöbb esetben kihozható a maximálisan elérhető hasznosság majdnem 90\%-a. 100 százalék akkor érhető el, ha minden eszközt megvennék, amelyet a potenciális hallgatók használhatnak.

\section{Adatgyüjtés}

A szekunder kutatáshoz kvalitatív és kvantitatív módszereket egyaránt használtam.

Első körben fókuszcsoportos interjúra került sor 2013 novemberében. Az interjú alanyai BA kereskedelem-marketing szakos hallgatók voltak. Összesen 12 elsőéves diákot kérdeztünk meg a felvételivel kapcsolatos információforrásokról, hisz még friss élménnyel rendelkeztek a témával kapcsolatban. A kvalitatív kutatás célja az volt, hogy a felhasznált nemzetközi és hazai szakirodalom által említett továbbtanulással kapcsolatos információforrásokat, valamint a potenciális hallgatók elérése érdekében használt marketingkommunikációs eszközöket kiegészítsük.

A továbbtanulni szándékozó diákok információgyüjtési szokásairól egy teljes évet átölelö longitudinális adatsor áll rendelkezésünkre. A 2013-2014es tanévben kérdöives megkérdezést hajtottunk végre három lépcsőben, amelyben a továbbtanulni szándékozó, vagy ahhoz korban közel álló diákok felvételire, egyetemválasztásra vonatkozó kommunikációs szokásairól, információgyüjtéséről gyüjtöttünk be adatokat. Az adat begyüjtése tehát 12 hónapra vonatkozott 2013 szeptemberétől 2014 augusztusáig 3 lépcsőben (egy kérdöív 4 hónapot ölelt át), így egy teljes évet átölelő longitudinális adatsor áll rendelkezésünkre a témában, amely részletes elemzéseket tett lehetővé.

1. táblázat: A longitudinális megkérdezés részletei

\begin{tabular}{|l|l|}
\hline Alapsokaság & $\begin{array}{l}\text { Egy szakközépiskola végzős diákjai (érettségi elött állók és } \\
\text { szakképzösök), N=210 }\end{array}$ \\
\hline Mintavételi keret & Elektronikus napló \\
\hline Mintavételi technika & Teljeskörü megkérdezés \\
\hline Válaszadási arány & $175 / 210$ \\
\hline Információgyújtés & Önkitöltős kérdőív \\
\hline Megbízhatóság & $\pi=95 \%$ \\
\hline Pontosság & $\Delta= \pm 3$ \\
\hline A minta megoszlása nemek szerint & férfi=41\%; nő=59\% \\
\hline Képzési szint szerint & $\begin{array}{l}\text { Érettségi elött álló végzősök=51\%; érettségi utáni } \\
\text { szakképzés }=49 \%\end{array}$ \\
\hline Válaszadók életkora: & $17-24$ \\
\hline
\end{tabular}

Forrás: Saját szerkesztés 
A panel tagjai Miskolc legelső kereskedelmi szakközépiskolájából (most már szakgimnáziumából) kerültek ki, akikre azért esett a választásunk, mert hozzájuk volt mindössze hozzáférésünk a kutatás elvégzéséhez. Ami a képzés típusát illeti, 49 százalékuk érettségi utáni szakképzésben vett részt ( 86 fö) (jó részük még szeretne egy szakmánt megszerzeni a felsőoktatásba való bekerülés előtt), míg 51 százalékuk érettségi előtt álló végzősök ( 89 fö). Teljes körủ megkérdezést hajtottunk végre, a válaszadók mindegyike egyetemi felvételi előtt állt, a megkérdezés évében érettségizett, vagy már túl lett rajta. A kvantitatív kutatás azt vizsgálta, hogy a diákok a egy adott tanév adott hónapjában milyen információforrásból tájékozódnak a felvételivel és a felsőoktatási intézményekkel kapcsolatban, illetve mikor, hogyan milyen kommunikációs eszközökkel lehet őket a legjobban elérni.

A kvantitatív kutatást újabb kvalitatív kutatás követte. A szakértői mélyinterjú célkitüzései többek között az egyetem által használt kommunikációs eszközök hasznosságával, költségvonzatával voltak kapcsolatosak, illetve hogy egyáltalán a rendelkezésre álló információforrások közül melyek voltak azok, amelyekkel egy adott intézmény él. Ezen felül kíváncsiak voltunk, hogy miként kerül beindításra egy beiskolázási kampány, és hogy egy ilyen büdzsé miből tevődik össze.

\section{Az UNIPOM modell által elért hasznosságok}

A szoftverbe betáplált eszközök száma 33 darab, amelyek zömét mind a 12 hónapban használni szeretnénk (természetesen vannak olyan eszközök is köztük, nyílt nap, kiállitás, amelyek egy évben csak egyszer merülnek fel). Továbbá olyan eszközök is, amelyekkel felesleges egyes hónapokban számolnunk. A középiskolai tanárok felkeresése véleményünk szerint májustól augusztus végéig mellőzhető, hisz májusban és júniusban az érettségi, ballagás, stb. miatt elfoglaltak, illetve július elején megkezdik nyári szünetüket. A pályaválasztási tanácsadók (esetünkben olyan szakember, aki a diákoknak adhat tanácsot, hogy milyen irányban folytassák tanulmányaikat, a meglévő kompetenciák figyelembevételével) tekintetében hasonlóan vélekedtünk, bár mivel nem feltétlenül kell, hogy tanárok legyenek, ezért a májusi hónapot esetükben meghagytuk. Így összesen 291 változóval számol a szoftver, mivel azok úgy vannak betáplálva a szoftverbe, hogy pl. helyi napilapok január, rádióban sugározott reklámok december, stb.

Ahhoz, hogy mindegyik kommunikációs eszközt használni tudjuk összesen 98.302.000 Ft. keretre lenne szükség, ekkor lenne 100\% hasznunk, ezt tekintjük maximális haszonnak.

Ahhoz, hogy eldöntsük, hogy milyen összegekben érdemes részletesen vizsgálódni, a szoftver segítségével 10 millió forintonként megnéztük, hogy hány egységnyi haszonra tehetünk szert. (1. ábra) eltérő büdzsével. Az X tengely az árat jelöli, az Y tengely pedig az elérhető hasznosságot egységben megadva, illetve az adatfeliratok segítségével jelöltük, hogy hogyan alakul az elért haszon az elérhető maximális haszonhoz viszonyítva. 


\section{1. ábra: Elérhető haszon különböző keretösszegek esetében}

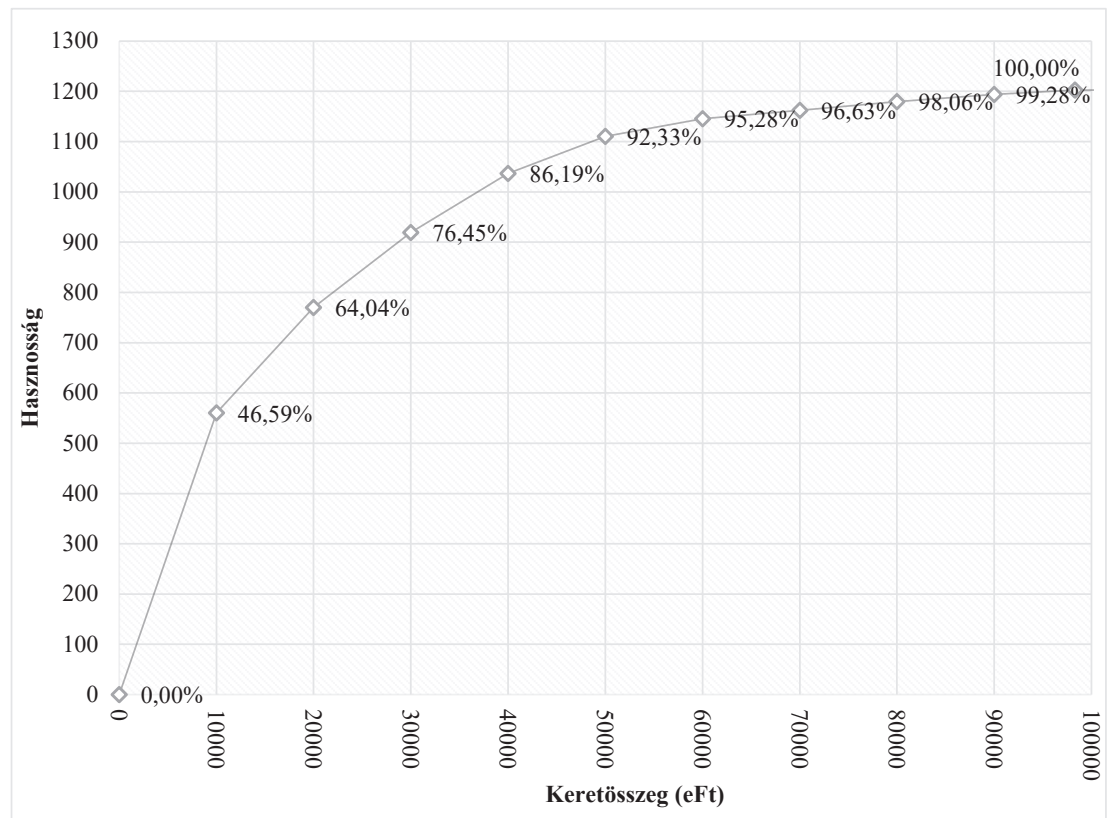

Forrás: saját szerkesztés

Mivel a szoftver segítségével már a maximális haszon eléréséhez szükséges összeg $(98.302 .000$ Ft) feléből is kihozható a maximálisan elérhető haszon (1202,59 egység $=100 \%$ haszon) $98,1 \%$-a, ezért úgy döntöttünk, hogy ez alatt az összeg alatt szeretnénk három verziót bemutatni, jelen esetben 15, 25 és 40 millió forintból szeretnénk gazdálkodni.

H: Elöfeltevésünk szerint a dinamikus programozás elvén müködő UNIPOM szoftver segítségével a rendelkezésre álló szükös büdzséböl magasabb hatékonyságú marketingkommunikációs mixet lehet generálni, mint amikor a pénz szétosztása egyedül emberi döntésen alapul.
A 2. táblázat 3 különböző keretösszeg esetén tartalmazza a használandó marketingmixek listáját. Mint, ahogy korábban is megemlítettük a középiskolai tanárokat májustól szeptemberig, illetve a pályaválasztási tanácsadókat júniustól augusztusig nem keressük fel. A legkisebb keretösszeg esetén 13 eszköz került be a marketingmixbe, itt a TV interjúkat februártól szeptemberig nem alkalmazzuk. 25 millió forint esetén már 17 elem kerül felhasználásra, ezek közül az országos napilapokban csak májusban, illetve októbertől decemberig teszünk közzé hirdetéseket. A legnagyobb bemutatott keretösszeg esetében az algoritmus 20 eszköz használatát javasolja egész évben. 


\section{2. táblázat: Az algoritmus által javasolt kommunikációs eszközök listája különböző keretösszegek esetén éves szinten}

\begin{tabular}{|l|c|c|c|}
\hline \multirow{2}{*}{} & \multicolumn{3}{|c|}{ Beiskolázási kommunikációra szánható keretösszegek } \\
\cline { 2 - 4 } & $15 \mathrm{mFt}$ & $25 \mathrm{mFt}$ & $40 \mathrm{mFt}$ \\
\hline Országos napilapok & & + & + \\
\hline Hetilapok & & + & + \\
\hline Havonta megjelenő magazinok, folyóiratok & & & + \\
\hline Rádiómüsorok elcsípett információk & + & + & + \\
\hline Rádióban sugárzott reklámok & & + & + \\
\hline TV Interjúk & + & + & + \\
\hline Híradóban elcsípett információ & + & + & + \\
\hline TV műsorok közben elcsípett információk & + & + & + \\
\hline Felvi honlapon való hirdetés & & + & + \\
\hline Educatio honlap & & + & + \\
\hline Egyetemek, föiskolák honlapjai & + & + & + \\
\hline Facebook & + & + & + \\
\hline Hírlevelek & + & + & + \\
\hline Internetes reklámfilmek & + & + & + \\
\hline Youtube & + & + & + \\
\hline Hírportálokon hirdetések, cikkek & + & + & + \\
\hline Szórólapok és egyetemi kiadványok & + & + & + \\
\hline Barátok, családtagok, ismerősök, rokonok & + & + & + \\
\hline Középiskolai tanárok & + & + & + \\
\hline Pályaválasztási tanácsadók & + & + & + \\
\hline
\end{tabular}

Forrás: saját szerkesztés

Az algoritmus és a szakértöi hatékonyság összevetése terjedelmi okok miatt csak a legkisebb keretösszeggel kerül bemutatásra. Elöször az egyes blokkokra (rádió, nyomtatott sajtó, tv, internet, programok, egyéb, stb.) fordított összegek és azok százalékos megoszlását vettük alapul. A szakértő által elosztott keretösszegek százalékos megoszlása a szakértői mélyinterjún elhangzottak alapján került meghatározásra. Az így kapott összegek, illetve a szoftver által szétosztott összegek összehasonlítását az alábbi táblázat tartalmazza 15 millió forintból. 


\section{3. táblázat: Blokkokra fordított összegek 15 mFt-ból a szoftver és a szakértő által éves szinten}

\begin{tabular}{|l|c|c|c|c|}
\hline \multirow{2}{*}{} & \multicolumn{2}{|c|}{ Szoftver } & \multicolumn{2}{c|}{ Szakértö } \\
\cline { 2 - 5 } & összeg Ft-ban & összeg \%-ban & összeg Ft-ban & összeg \%-ban \\
\hline Nyomtatott sajtó & 0 & 0 & 3.750 .000 & $25 \%$ \\
\hline Rádió & 1800.000 & $12 \%$ & 750.000 & $5 \%$ \\
\hline Televízió & 1.500 .000 & $10 \%$ & 1.500 .000 & $10 \%$ \\
\hline Internet & 9.792 .000 & $65 \%$ & 5.250 .000 & $35 \%$ \\
\hline Rendezvény & 0 & 0 & 3000.000 & $20 \%$ \\
\hline Egyéb & 1.880 .000 & $13 \%$ & 750.000 & $5 \%$ \\
\hline Összesen & 14.972 .000 & $100 \%$ & 150000.000 & $100 \%$ \\
\hline
\end{tabular}

Forrás: saját szerkesztés

A következőkben azt szerettük volna megtudni, hogy a szoftver segítségével, vagy az adott összegek emberi döntésen alapuló szétosztásával lehet-e nagyobb hasznosságra szert tenni. Mivel a szoftver esetében egyes eszközök hasznossága elérhető és pontosan tudjuk, hogy a szoftver milyen eszközöket válogatott be, így a hasznosságok összegzésével máris eredményre jutottunk. Azonban a szakértői eredményesség meghatározásánál nem volt ilyen egyszerü a feladat, mert nem tudjuk pontosan, hogy egyes blokkok (pl. internet, tévé, stb.) esetében adott keretösszegnél milyen eszközök kerülhetnének bele a szakértői marketing mixbe. Először azt határoztuk meg, hogy egyes blokkoknak mennyi az 1 millió forintra jutó haszna. Ehhez először meg kellett állapítanom, hogy az adott blokkal mennyi a maximális összhasznot lehet elérni. Mivel minden egyes eszköz haszna az adatbázisban elérhető, ezért összeadtuk az egyes blokkokba tartozó eszközök hasznát egy teljes évre vonatkozóan. A maximális haszon eléréséhez szükséges költségeket blokkonként a 3. táblázat szakértöi része tartalmazza.

A kapott összegeket felszoroztuk az adott blokkra költhetö összegekkel.

\section{4. táblázat: Emberi döntéssel elérhető hasznosság blokkonként 15 millió forintból éves szinten}

\begin{tabular}{|c|c|c|c|c|c|}
\hline & $\begin{array}{c}\text { adott blokkal } \\
\text { elérhető max. } \\
\text { haszon }\end{array}$ & $\begin{array}{c}\text { max haszon } \\
\text { eléréséhez } \\
\text { szükséges ktg. } \\
\text { blokkonként } \\
\text { (mFt) }\end{array}$ & $\begin{array}{c}\text { 1mFt-ra jutó } \\
\text { haszon } \\
\text { blokkonként }\end{array}$ & $\begin{array}{c}\text { adott } \\
\text { blokkra } \\
\text { költhetö } \\
\text { összeg mFt }\end{array}$ & $\begin{array}{c}\text { adott } \\
\text { blokkal } \\
\text { elérhetö } \\
\text { haszon }\end{array}$ \\
\hline Nyomtatott sajtó & 166,67 & 14.040 & 11,87 & 3,750 & 44,51 \\
\hline Rádió & 87,41 & 4.080 & 21,42 & 7,5 & 16,07 \\
\hline TV & 164,56 & 8.580 & 19,18 & 15 & 28,77 \\
\hline Internet & 483,01 & 19.272 & 25,06 & 5,25 & 131,57 \\
\hline Rendezvények & 66,59 & 44.100 & 1,51 & 3 & 4,53 \\
\hline Egyéb & 234,36 & 8.230 & 28,48 & 0,750 & 21,36 \\
\hline Összesen & 1202,60 & 98.302 & & 15 & 246,80 \\
\hline
\end{tabular}

Forrás: saját szerkesztés 
A kiszámolt szakértői hasznosság jóval kevesebb a szoftver által elért hasznosságnál, hisz a maximális hasznosság mindössze 20,52\%-át érhetjük el hagyományos módon.

A következő táblázat a szakértő és a dinamikus programozás elvén müködő szoftver által elért maximális hasznosságot hasonlítja össze a három keretösszeg esetén. Természetesen ha a büdzsé magasabb, akkor a szakértő által elérhető haszon is növekedni fog mivel több marketingkommunikációs eszközt tud megvásárolni és azok hasznossága összaadódik. Magasabb keretösszegek esetén a szakértő és a szoftver közötti maximálisan elérhető haszon között is egyre kisebb lesz a különbség. Itt újból megjegyezzük, hogy az UNIPOM modellt szükösebb büdzsé esetére fejlesztettük ki.

\section{5. táblázat: Adott keretösszegek mellett realizált haszon}

\begin{tabular}{|c|c|c|c|c|}
\hline \multirow{2}{*}{ Büdzsé } & \multicolumn{2}{|c|}{ Szakértő } & \multicolumn{2}{c|}{ UNIPOM szoftver } \\
\cline { 2 - 5 } & Haszon & $\begin{array}{c}\text { Elérhető haszon a } \\
\text { maximális elérhető } \\
\text { haszon \%-ban }\end{array}$ & Haszon & $\begin{array}{c}\text { Elérhető haszon a } \\
\text { maximális elérhető } \\
\text { haszon \%-ban }\end{array}$ \\
\hline $15 \mathrm{mFt}$ & 246,8 & $20,52 \%$ & 682,99 & $56,79 \%$ \\
\hline $25 \mathrm{mFt}$ & 411,34 & $34,20 \%$ & 848,07 & $70,52 \%$ \\
\hline $40 \mathrm{mFt}$ & 658,14 & $54,73 \%$ & 1036,51 & $86,19 \%$ \\
\hline
\end{tabular}

Forrás: saját szerkesztés

Az alábbi megállapitást tehetjük: A dinamikus programozás elvén müködö UNIPOM szoftver a beiskolázási kommunikációra forditható szükös eröforrás allokációját nagyobb hasznosságot eredményezöen képes elvégezni, mint amikor a pénz szétosztása csupán emberi döntésen (szakértök) alapul.

Az adatokból jól kivehető, hogy a dinamikus programozás elvén müködő egyetemi promóció optimalizációs szoftver (UNIPOM) segítségével, szükösebb költségvetés esetén magasabb hasznosságú marketing kommunikációs mix hozható létre, tehát a hipotézist elfogadjuk.

\section{KÖVETKEZTETÉS}

A létrehozott UNIPOM szoftver a dinamikus programozás elvén müködik, amely az ár és a hasznosság összevetésével hátizsák feladat megoldásával szükiti le a marketinkommunikációs eszközöket létrehozva legoptimálisabb és leghatékonyabb marketingmixet. A szoftver a beiskolázási kommunikációra fordítható szükös erőforrás allokációját jobb eredményt biztosítva végzi el, mint amikor a pénz szétosztása csupán emberi döntésen (szakértők) alapul.

A modell felállításában azonban korlátokba is ütköztünk, hisz arról nem kaptunk információt, hogy egyes eszközökre mennyit költ az egyetem, ezért különböző forrásokból gyüjtöttünk információt az eszközök költségességének meghatározásához. A tényleges áraktól eltérhetnek a modellben alkalmazott adatok, de ahhoz elegendö, hogy szemléltessük a promóció optimalizációs modell gyakorlati hasznát.

Attól függően, hogy hol hirdetünk különböző árakat kapunk, valamint az, hogy egyes eszközökre pontosan mennyit költ az egyetem bizalmas adat. Az árak becsléséhez interneten hozzáférhetők egyes egyetemek kommunikációs tervei. Ezen felül megnéztük a hirdetési felületek aktuális árait is (például internetes portálok hirdetési árai, helyi lapok hirdetési árai, rádiók honlapjai).

Egyes információ források esetében, közvetlenül nem mérhető költségekröl beszélünk, ezért nem számolnánk fel árakat. Azonban egy minimális költséget megadtunk, mivel közvetve biztosan van költsége. Ilyenek például a referencia csoport, barátok, rokonok, stb., hisz valamilyen forrásból ők is tájékozódnak és nem csupán saját tapasztalataik alapján (esetleg korábbi diákokról van szó) ajánlhatják az adott egyetemet, hanem hallottak róla tévéből, rádióból, olvastak róla valamilyen újságból, hírportálról, stb. Mivel lényeges szerepet játszanak az adott diák választásában ezért nem hagytuk öket ki a szoftverből. 
Egy másik fontos dolog, amit mindenképpen szükséges figyelembe venni az, hogy egyes eszközök hasznossága változhat, ezért bizonyos időközönként szükséges tartani egy újabb kérdőíves megkérdezést, hogy pontos adatokkal dolgozzunk. Szintén lényeges elem az árváltozás, amit mindig figyelemmel kell kísérni.

A szoftver által kiszámított eredmények segíthetnek a különböző kommunikációs eszközökre fordítható összegek hatékonyabb allokációjában, azonban fontos megjegyeznünk, hogy a drágább eszközök egy alacsonyabb büdzsé esetében nem kerülnek bele a marketingmixünkbe, de lehet, hogy az adott összegből mindenféleképpen fordítanánk drágább eszközökre is, mivel például a nyílt nap, kiállítás imázs szempontjából kiemelt jelentőséggel bírnak. Ezért újból felhívjuk a figyelmet arra, hogy a modellt döntés támogatói céllal hoztuk létre a felsőoktatásban dolgozó beiskolázással foglalkozó szakértők számára. A tanulmányban a modell, és a hozzá kapcsolódó algoritmus gyakorlati hasznára szeretnénk felhívni figyelmet.

Habár az integrált marketingkommunikáció alapgondolata szerint a kommunikációs elemek szinergiát eredményeznek, a modell a változókat függetlenként kezeli. A változók közötti kapcsolatokat a jövőben vizsgálni szeretnénk és a modellt is ennek megfelelően módosítanánk, hogy egyes eszközök milyen hatással vannak egymásra, melyek azok az eszközök, amelyek együttes alkalmazása nagyobb hasznot eredményezhet és melyek azok, amelyek egymást gyengítik.

A modell jövőbeli finomítása után nagyobb mintán és más közegen is tesztelnénk a kutatási eredményeket. Több lekérdezést is szeretnénk majd lefolytatni különböző középiskolában attól függően, hogy miként változhatnak a hasznosságok különböző szakok és képzési területek esetében. Egyenlöre csak azt szeretnénk demonstrálni, hogy a kutatásban bemutatott modell és a hozzá kapcsolódó algoritmus segíthet egy eredményesebb egyetemi beiskolázási marketingkommunikációs mix létrehozásában.

Továbbá megjegyezzük, hogy a szoftvert mindössze döntéstámogatói célra javasoljuk, ahhoz, hogy a beiskolázási kampányra fordítható keretösszeg allokációját a beiskolázási szakértők minél eredményesebben tudják elvégezni, mivel a szakértők tudásával, tapasztalatával lehet sikeres egy beiskolázási stratégia. A modell kiterjesztésével, a változók modosításával a módszert alkalmazni lehet bármilyen szervezet promóciójának alaposabb megtervezéséhez.

\section{HIVATKOZÁSOK}

AGB Nielsen (2018), „Arianna teljes brossúra”, Letöltés: 2018.10.03. Forrás: http://www.agbnielsen.com/Uploads/Hungary/Arianna_teljes_brossura.pdf

Aggarwal, S., Gupta, A., Kaul, A., Krishnamoorthy M. (2017), „Multiproduct Dynamic Advertisement Planning in a Segmented Market", Yugoslav Journal of Operations Research, 27 2, 169204

Bányai E. - Dudás K. (2010), “Az Internet szerepe a felsőoktatási beiskolázási marketingben, illetve az intézményválasztási folyamatban”, szerk. Kuráth, G., Pálfi M., III. Felsőoktatási Marketing Konferencia CD, Pécs: Pécsi Tudományegyetem Közgazdaságtudományi Kar (PTE KTK), 231-47

Bajalinov E. - Imreh B. (2001), Operációkutatás, Szeged: Polygon Jegyzettár

Bass, F. M., Lonsdale R. T. (1966), „An Exploration of Linear Programming in Media Selection" Journal of Marketing Research, 3 2, 17988 DOI: https://doi.org/10.2307/3150208

Bellman, R. (1954), „The theory of dynamic programming", Bulletin of the American Mathematical Society, 503-16

Bogáromi E. - Máth A. (2015), “Sokforrású adatbázis-építés - buktatók, nehézségek, megoldási kísérletek", EDUCATIO, 24 3, 86-9

Brown, D. B., Warshaw, M. R. (1965), „Media selection by linear programming". Journal of Marketing Research, 2 1, 83-8 DOI: https://doi. org $/ 10.2307 / 3149343$

Charnes, A., Cooper,W.W., De Voe, J.K., Learner, D.B., and Reinecke,W., (1968), "A goal programming model for media planning", Management Science, 14 8, 13423-13430 DOI: https:// doi.org/10.1287/mnsc.14.8.b423

Consumer Barometer (2018), „Trended data”, Letöltés dátuma: 2018. 04 10., forrás: www. consumerbarometer.com

Csipkés M. - Bácsi B. (2018), “A marketingkommunikációs eszközök jelentősége a fiatalok körében“, E-conom, 7 1, 39-50 DOI: https://doi. org/10.17836/ec.2018.1.039

Cormen, T. H., Leiserson, C. E., Rivest, R. L., Stein, C. (2001), Introduction to Algorithms, 2/e. MIT Press

Dantzig, T. (1930), Numbers, The Language of Science, New York: New Press

Dasgupta, S., Papadimitriou, C. H., Vazirani, U. V. (2006), Algorithms, McGraw-Hill. 
Duga Zs. (2014), „Felvételi információforrások 2010-2013”, in: Kuráth G., Héráné Tóth A., Sipos N., (szerk), PTE Diplomás Pályakövetö Rendszer tanulmánykötet 2014, Pécs, Pécsi Tudományegyetem, 18-37

Felvi.hu. (2018), "Friss statisztikák: Jelentkezők és felvettek összesen" Letöltés dátuma: 2018. október 23. forrás: https://www.felvi.hu/felveteli/ponthatarok_statisztikak/friss_statisztikak/!FrissStatisztikak/index.php/friss_statisztikak/ osszesen

Fernandez, P. J., Vargas, F. G., de Sauza Lauretto, M., de Brangancia Pereira, C. A., Stern, J. M (2007), „A new media optimizer based on the mean-variance model", Pesquisa Operacional, 27 3, 427-53 DOI: https://doi.org/10.1590/ s0101-74382007000300003

Garamvölgyi L. (2017), "Informatikai fejlesztések könyvtári környezetben", Tudományos és Müszaki Tájékoztatás, 6 289-97

Gemius Hungary (2018), “Kutatás”, Megtekintés dátuma: 2018. 10. 04. Forrás: http://www gemius.hu/kutatas.html

Gyulavári T. és Hubert J. (2014), „A hatásosság és hatékonyság fogalmainak értelmezése online vs. offline kampányok keretében" In: Hetesi E., Révész B (szerk.) „Marketing megújulás”: Marketing Oktatók Klubja 20. Konferenciája, Szeged, 302-10

Hack-Handa J. és Pintér T. (2015), “Generációs különbségek a magyar médiafogyasztásban“ Információs Társadalom, 15 2, 7-17

Hubert J. (2016), „Marketingmérés - két eset az on-line marketing világából", Vezetéstudomány, 48 2, 41-54

Katona F. (2015), A marketing-kontrolling alkalmazásának jelentősége a kis-, és közepes vállalkozások eredményességében, Gödöllő: Doktori értekezés, Szent István Egyetem, Gazdaság-, és Társadalomtudományi Kar

Kéri A. (2016), “A magyar felsőoktatásban tanuló külföldi hallgatók motivációjának vizsgálata”, E-CONOM, 5 1, 35-50 DOI: https://doi. org/10.17836/ec.2016.1.036

Kosterich, A. and Napoli, P. (2016), "Reconfiguring the Audience Commodity: The Institutionalization of Social TV Analytics as Market Information Regim", Television \& New Media, 17 3, 254-71 DOI: https://doi. org/10.1177/1527476415597480

Kovácsné Tóth Á. - Zakariás G. (2010), „Nemcsak a húszéveseké a világ”, in: Kuráth, G., Pálfi M. (szerk.), III. Felsőoktatási Marketing Konferencia $C D$, Pécs: Pécsi Tudományegyetem Közgazdaságtudományi Kar (PTE KTK), 188-99
Központi Statisztikai Hivatal (KHS) (2018), „Eurostat statikus táblák”, Letöltés dátuma: 2018. október 22, forrás: https://www.ksh.hu/ docs/hun/eurostat_tablak/tabl/tps00001.html

Kun A. - Svanter B. (2014), "Beiskolázási nyílt napok a felsőoktatási marketingben - egy felméréssorozat tanulságai", in: Hetesi E. Révész B. (szerk.): „Marketing megújulás”. Marketing Oktatók Klubja 20. Konferencia elöadásai, Szeged: Szegedi Tudományegyetem Gazdaságtudományi Kar 416-23

Kuráth G. (2008). A beiskolázási marketing szerepe a hazai felsőoktatási intézmények vonzeröfejlesztésében, Pécs: Doktori értekezés, Pécsi Tudományegyetem Közgazdaságtudományi Kar (PTE KTK)

Lévai R. (2018.), "Közösségi Kalandozások", Letöltés dátuma: 2018. 10. 20, Forrás: http:// kozossegikalandozasok.hu/2018/02/14/mennyi-embert-erhetunk-el-facebook-hirdetesek$\mathrm{kel} /$

Manoku, E. (2015), „Factors that influence choice of Albanian students", European Scientific Journal, 11 6, 253-70

Marino, V. and Presti, L. (2016), „Social Media Mix in the University Communication Plan: A Bridge Towards Public Engagement", In: Petruzzellis, L. \& Winer, R. (Eds:), Rediscovering the Essentiality of Marketing, Developments in Marketing Science: Proceedings of the Academy of Marketing Science, Springer, 275-81 DOI: https://doi.org/10.1007/978-3-319-29877$1 \_57$

Mathews, G. (1897), "On the partition of numbers", Proceedings of the London Mathematical Society, 486-90

Nagy T. (2007), Operációkutatás, Miskolc: Miskolci Egyetemi Kiadó

Nie, Z. \& Kambhampati, S. (2001), "Joint Optimization of cost and coverage of query plans in data integration" Proceedings of the Tenth International Conference on Information and Knowledge Management, Atlanta, 223-30 DOI: https://doi.org/10.1145/502620.502623

Nocedal, J., Wright, S. (2006), Numerical Optimization, New York: Springer

Oktatási Hivatal. (2016), “OH MÉDIA 2016: a fiatalok figyelnek ránk“", Letöltés: 2018.05.12, Forrás: https://www.felvi.hu/pub bin/dload/media/ $\mathrm{OH} \_$mediaajanlat.pdf

Piskóti I. (2008), „A felsőoktatás marketing szemlélete és modellje", In: Piskóti I. (szerk) Marketing kaleidoszkóp, Miskolc: Miskolci Egyetem Gazdaságtudományi Kar, 105-23 
Piskóti I. (2011). „Módszertani és szervezeti megoldások az egyetemi marketingben." Felsőoktatási Mühely, 2 39-51

Piskóti I (2017). „Egyetemi marketingstratégia keretei a sikeres üzleti, innovációs együttmüködésekben", In: Csiszár Cs. M. (szerk.) Jubileumi tanulmánykötet Illés Mária professzor asszony 70. születésnapjára, Miskolc: Miskolci Egyetem Gazdaságtudományi Kar, 119-29

Polónyi I. (2016), "Felsőoktatás a koncepciók keresztútján“, Köz-Gazdaság, 2, 209-22

Samuelson P. A. and Nordhaus W. D (2012): Közgazdaságtan. Bővített, átdolgozott kiadás. Akadémiai Kiadó, Budapest

Solcansky, M., Simberova, I. (2010), "Measurement of Marketing Effectiveness", Economics and Management, 15 755-9

Szijártó Zs., Glózer R., Guld Á., Csóka L., Töröcsik M. (2018) Média: a magyar lakosság médiumkörnyezettel és médiahasználattal kapcsolatos beállitódása generációs szemléltető vizsgálattal - országosan reprezentatív online megkérdezés (1038), valamint fókuszcsoportos viták eredményei, Pécs: Pécsi Tudományegyetem Közgazdaságtudományi kar

Temesi J. és Varró Z. (2007), Operációkutatás, Budapest: Aula Kiadó

The Statistics Portal. (2018), "Global social networks rankedby number of users", Letöltés dátuma: 2018. 04. 14, Forrás: https://www. statista.com/statistics/272014/global-social-networks-ranked-by-number-of-users/

Világnépesség térkép (2018), “Világ jelenlegi népessége" Letöltés: 2018. 04.14, Forrás: http:// nepesseg.population.city/world

Wimmer Á. (2002), Üzleti teljesitménymérés, Budapest: Budapesti Közgazdaságtudományi és Államigazgatási Egyetem, Vállalatgazdaságtan tanszék 
Molnárné Konyha Csilla PhD hallgató csilla.konyha@gmail.com Miskolci Egyetem Marketing és Turizmus Intézet

\section{Promotion optimization for universities with dynamic programing}

\section{THE AIMS OF THE PAPER}

The aim of the present study is the detailed description of such a promotion optimization model for universities (UNIPOM) that makes possible to set up the most effective marketing communication mix in case of scarce financial resource with the help of the software created for this purpose.

\section{METHODOLOGY}

Longitudinal investigation, focus group interview, survey carried out with questionnaire, in-depth interview, knapsack (0-1), dynamic programing

\section{MOST IMPORTANT RESULTS}

Most important results of the research is such a longitudinal data that could give me a full picture about the information gathering habits of the potential students about their admission and their university choice in each month of the year that is when, how, and with which communication tools are the most effective to reach them. In this way, knowing the effectiveness and prices of each tool, it is also possible to set up the most effective marketing mix even in case of scarce budget. This can be achieved by the university promotion optimization software (UNIPOM) that can realize an effectiveness above $90 \%$ from half of the budget needed for the purchase of all tools used for student recruitment.

\section{RECOMMENDATIONS}

It is important to mention that the optimization model for universities detailed in the present study was created with decision support goal for the specialists dealing with student recruitment in higher education and I hope they will find my research useful for the creation of a successful student recruitment campaign and giving a base for their strategy.

Keywords: higher educational marketing, student recruitment, promotion optimization model for universities (UNIPOM) 